\title{
Title: Myocarditis and Pericarditis following COVID-19 Vaccination: Evidence Syntheses on Incidence, Risk Factors, Natural History, and Hypothesized Mechanisms
}

Authors: Jennifer Pillay, $\mathrm{MSc}^{1}$, Lindsay Gaudet, $\mathrm{MSc}^{1}$, Aireen Wingert, $\mathrm{MSc}^{1}$, Liza Bialy, $\mathrm{MSc}^{1}$, Andrew S. Mackie, MD, SM, FRCPC ${ }^{2}$, D. Ian Paterson, MD, FRCPC ${ }^{3}$, Lisa Hartling, $\mathrm{PhD}^{1}$

\author{
Affiliations: \\ ${ }^{1}$ Alberta Research Centre for Health Evidence, Department of Pediatrics, University of Alberta, \\ Edmonton, Canada \\ ${ }^{2}$ Department of Pediatrics, Division of Pediatric Cardiology, University of Alberta, Edmonton, Canada \\ ${ }^{3}$ Department of Medicine, Division of Cardiology, University of Alberta, Edmonton, Canada
}

Funding statement: This project was funded by the Canadian Institutes of Health Research (CIHR) through the COVID-19 Evidence Network to support Dec ision-making (COVID-END) at McMaster University and the SPOR Evidence Alliance. The funders provided input on the design of the study, but did not take part in the collection, analysis, or interpretation of data. They reviewed a report generated from the findings but did not make decisions about submission of the article for publication. Dr. Hartling is supported by a Canada Research Chair in Knowledge Synthesis and Translation, and is a Distinguished Researcher with the Stollery Science Lab supported by the Stollery Children's Hospital Foundation.

Declaration of competing interests: The authors have no competing interests to declare. 
medRxiv preprint doi: https://doi.org/10.1101/2022.02.28.22271643; this version posted March 1, 2022. The copyright holder for this preprint (which was not certified by peer review) is the author/funder, who has granted medRxiv a license to display the preprint in perpetuity. It is made available under a CC-BY-NC 4.0 International license .

\section{Abstract (595 words)}

Objectives: Myocarditis and pericarditis are adverse events of special interest after vaccination for COVID-19. Evidence syntheses were conducted on incidence rates, risk factors for myocarditis and pericarditis after COVID-19 mRNA vaccination, clinical presentation and short- and longer-term outcomes of cases, and proposed mechanisms and their supporting evidence.

Design: Systematic reviews and evidence reviews.

Data sources: Medline, Embase and the Cochrane Library were searched from October 2020 to January 10, 2022; reference lists and grey literature (to January 13, 2021).

Review methods: Large ( $>10,000)$ or population-based/multisite observational studies and surveillance data (incidence and risk factors) reporting on confirmed myocarditis or pericarditis after COVID-19 vaccination; case series ( $\mathrm{n} \geq 5$, presentation, short-term clinic al course and longer-term outcomes); opinions/letters/reviews/primary studies focused on describing or supporting hypothesized mechanisms. A single review er completed screening and another verified $50 \%$ of exclusions, using a machine-learning program to prioritize records. A second reviewer verified all exclusions at full text, extracted data, and (for incidence and risk factors) risk of bias assessments using modified Joanna Briggs Institute tools. Team consensus determined certainty of evidence ratings for incidence and risk factors using GRADE.

Results: 46 studies were included (14 on incidence, 7 on risk factors, 11 on characteristics and short-term course, 3 on longer term outcomes, and 21 on mechanisms). Incidence of myocarditis after mRNA vaccines is highest in male adolescents and young adults (12-17y: range 50-139 cases per million [low certainty] and 18-29y: range 28-147 per million [moderate certainty]). For 5-11 year-old males and females and females 18-29 years of age, incidence of myocarditis after vaccination with Pfizer may be fewer than 20 cases per million (low certainty). There was very low certainty evidence for incidence after a third dose of an mRNA vaccine. For 18-29 year-old males and females, incidence of myocarditis is probably higher after vaccination with Moderna compared to Pfizer (moderate certainty). Among 12-17, 18-29 and 18-39 year-olds, incidence of myocarditis/peric arditis after dose 2 of an mRNA vac cine may be lower when administered $\geq 31$ days compared to $\leq 30$ days after dose 1 (low certainty). Data specific to males aged 18-29 indicated that the dosing interval may need to increase to $\geq 56$ days to substantially drop incidence. For clinical course and short-term outcomes only one small series $(n=8)$ was found for $5-11$ year olds. In cases of adolescents and adults, the majority ( $>90 \%$ ) of myocarditis cases involved 20-30 year-old males with symptom onset 2 to 4 days after second dose (71-100\%). Most cases were hospitalized ( $\geq 84 \%$ ) for a short duration (2-4 d). For peric arditis, data is limited but more variation has been reported in patient age, sex, onset timing and rate of hospitalization. Case series with longer-term (3 mo; $n=38$ ) follow-up suggest persistent ECG abnormalities, as well as ongoing symptoms and/or a need for medications or restriction from activities in $>50 \%$ of patients. 16 hypothesized mechanisms are described, with little direct supporting or refuting evidence.

Conclusions: Adolescent and young adult males are at the highest risk of myocarditis after mRNA vaccination. Pfizer over Moderna and waiting more than 30 days between doses may be preferred for this population. Incidence of myocarditis in children aged 5-11 may be very rare but certainty was low. Data on clinical risk factors was very limited. Clinical course of mRNA related myocarditis appears to be benign although longer term follow-up data is limited. Prospective studies with appropriate testing (e.g., biopsy, tissue morphology) will enhance understanding of mechanism(s). 
medRxiv preprint doi: https://doi.org/10.1101/2022.02.28.22271643; this version posted March 1, 2022. The copyright holder for this preprint (which was not certified by peer review) is the author/funder, who has granted medRxiv a license to display the preprint in perpetuity. It is made available under a CC-BY-NC 4.0 International license.

Funding and Registration no. This project was funded in part by the Canadian Institutes of Health Research (CIHR) through the COVID-19 Evidence Netw ork to support Decision-making (COVID-END) at McMaster University. Not registered.

\section{Summary box}

\section{What is already known about this topic?}

Case reports and surveillance signals of myocarditis (inflammation of the heart muscle) and pericarditis (inflammation of the two-layered sac surrounding the heart) after COVID-19 vac cination appeared as early as April 2021.

These have prompted ongoing surveillance and research of these complications to investigate their incidence, possible attribution to the vaccines, and clinical course.

\section{What this study adds}

This review critically appraises and synthesizes the available evidence to-date on the incidence of and risk factors for myocarditis and pericarditis after COVID-19 vaccination in multiple countries. It summarizes the presentation and clinical course of over 8000 reported cases and describes some initial reports of longer term outcomes. Further, many possible mechanisms are outlined and discussed.

Though low, the incidence of myocarditis is probably the highest in young males aged 12-29 years and is probably higher with Moderna than Pfizer mRNA vaccines. Longer dosing intervals may be beneficial. Most cases are mild and self-limiting, though data in 5-11 year-olds is very limited. Continued active surveillance with longer term follow-up is warranted. 
medRxiv preprint doi: https://doi.org/10.1101/2022.02.28.22271643; this version posted March 1, 2022. The copyright holder for this preprint (which was not certified by peer review) is the author/funder, who has granted medRxiv a license to display the preprint in perpetuity.

It is made available under a CC-BY-NC 4.0 International license .

\section{Introduction}

Case reports and surveillance signals ${ }^{1-4}$ of myocarditis (including myopericarditis) and pericarditis after COVID-19 vaccination appeared as early as April 2021, leading to the surveillance of adverse events of special interest following vacc ination with messenger RNA(mRNA) vaccines manufactured by Pfizer and Moderna. Estimated rates of myocarditis in the United Kingdom (UK) ${ }^{5}$ and the United States (US) ${ }^{67}$ are 11 and 1-2 cases per 100,000 person-years, respectively, regardless of age. Estimated background/expected rates of myocarditis and pericarditis following COVID-19 vaccination in the US, that is, adjusted for a 7-day risk period where most cases appear, are 0.2 and 1.4 per 1 million people, respectively. ${ }^{6}$ Historically, myocarditis has been more prevalent in males than females, from childhood through young adulthood, ${ }^{8}$ and this tendency was reflected in early post-COVID-19 vaccination case series. ${ }^{910}$

Symptoms indicative of myocarditis or pericarditis typically include new onset and persisting chest pain, shortness of breath, and/or palpitations. ${ }^{11}$ Diagnosis of a probable case of myocarditis usually requires elevated troponin levels and/or findings from imaging (e.g., echocardiography, magnetic resonance imaging) or other testing (e.g., ECG); histopathology for a definitive diagnosis is not usually performed. ${ }^{12}$ Differential diagnoses, including COVID-19 infection and community-ac quired myocarditis, should be considered and ruled out. ${ }^{12}{ }^{13}$ Most people experiencing these conditions will fully recover; however, in rare cases, myocarditis can lead to heart failure or asymptomatic left ventricular dysfunction. Long-term consequences associated with peric arditis include one or more recurrences and, rarely, thickening of the pericardium and constrictive heart filling. ${ }^{14}$

This evidence synthesis included systematic reviews of incidence rates ( 0 to 39 years) and risk factors for myocarditis and pericarditis after COVID-19 mRNA vaccination, evidence reviews of initial presentation and clinical course and of longer-term outcomes of cases, and a description of proposed mechanisms and their supporting evidence. Our original reviews (literature search October 6, 2021) on incidence rates, risk factors, and case presentation and short-term outcomes of myo- and/or pericarditis 
medRxiv preprint doi: https://doi.org/10.1101/2022.02.28.22271643; this version posted March 1, 2022. The copyright holder for this preprint (which was not certified by peer review) is the author/funder, who has granted medRxiv a license to display the preprint in perpetuity.

It is made available under a CC-BY-NC 4.0 International license .

after COVID-19 vaccination across all vaccines, ages and sexes indicated that incident rates were little-tonone after non-mRNA vaccines and in adults 40 years and older, that rates after mRNA vaccination varied by sex, age, and dose, and that the case characteristics and clinical course of myocarditis and pericarditis differ. ${ }^{15}$ There were no data on children aged $<12$ years or for people after receiving a third dose. For our review update reported herein, we refined the questions to focus on gaps and stakeholder/decision-maker priorities, specifically, mRNA vaccines, priority age and risk groups, and cases after a third vaccine dose. Where possible, we limited cases to those confirmed by medical record review and of myocarditis/myoperic arditis or pericarditis rather than in combination (when data were available separately). We also expanded the scope to include evidence on longer-term outcomes. Finally, we added descriptions and studies of hypothesized mechanisms. This report focuses on the refined questions but includes findings on characteristics and short-term clinical course of myocarditis or pericarditis after any dose of the vaccine across all ages from the original review.

\section{Review Questions}

1. What is the incidence of myocarditis and pericarditis following mRNA COVID-19 vaccination, by age and sex, in i) people 0-4 years, 5-11 years, 12-17 years, 18-29 years after their second dose, ii) recipients of any age after a third dose, and iii) individuals with prior history of myocarditis following mRNA COVID-19 vaccination?

2. Among individuals of a similar age and sex, are there risk or protective factors (e.g., pre-existing conditions [e.g. cardiac diseases, immunocompromise], previous SARS-CoV-2 infection [symptomatic or asymptomatic] or other viral infections, pharmac otherapies [e.g., hormones], type of vaccine product, length of vaccine dosing interval, vaccine combination for first vs second vs booster doses) for myocarditis and pericarditis following mRNA COVID-19 vaccination? 
medRxiv preprint doi: https://doi.org/10.1101/2022.02.28.22271643; this version posted March 1, 2022. The copyright holder for this preprint (which was not certified by peer review) is the author/funder, who has granted medRxiv a license to display the preprint in perpetuity.

It is made available under a CC-BY-NC 4.0 International license.

3.

a. What are the characteristics and short-term clinical course of myocarditis or pericarditis after COVID-19 vaccination, in i) children $<12$ yrs, ii) recipients of any age after a third dose, and iii) individuals with prior history of myocarditis following mRNA COVID-19 vaccination?

b. (From original review) What are the characteristics and short-term clinical course of myocarditis or pericarditis after COVID-19 vaccination (i.e., across all ages, after a second vaccine dose)

4. Among individuals of a similar age and sex who experienced myocarditis or pericarditis after mRNA COVID-19 vaccination, what is the longer term ( $\geq 4 \mathrm{w}$ eeks) prognosis, and does this vary by patient or vaccine characteristics?

5. What are the hypothesized mechanisms involved in myocarditis and pericarditis following vaccination with mRNA COVID-19 vaccines, and do they vary by group?

\section{Methods}

We conducted these evidence syntheses following a protocol developed before screening began. Know ledge users from the Public Health Agency of Canada (PHAC) contributed to scoping the reviews but did not participate in their conduct. We followed guidance for systematic reviews when conducting ${ }^{16}$ and reporting ${ }^{17}$ questions 1 and 2.

\section{Lite rature Se arch}

We worked with an experienced medical information specialist to develop the search strategy, which was peer-reviewed (see Acknowledgements). ${ }^{18}$ Searches combined concepts for COVID-19, vaccines, and myocarditis/pericarditis/cardiovascular manifestations/adverse events/surveillance; each concept included various key word and Medical Subject Heading (MeSH) terms. The search was originally run on October 6, 2021 and an update was run January 10, 2022; the update search (Appendix 1) was slightly modified from the original search (e.g., adding Omicron, removing non-mRNA vaccine terms). We did not add limits for language, country, or study design, but had limits for case reports and news/new spaper articles. Using the multifile option as well as the deduping tool in Ovid, we searched 
medRxiv preprint doi: https://doi.org/10.1101/2022.02.28.22271643; this version posted March 1, 2022. The copyright holder for this preprint (which was not certified by peer review) is the author/funder, who has granted medRxiv a license to display the preprint in perpetuity. It is made available under a CC-BY-NC 4.0 International license .

Ovid MEDLINE(R) and Epub Ahead of Print, In-Process, In-Data-Review \& Other Non-Indexed

Citations and Daily $<1946$ to January 10, 2022 > and Embase $<1974$ to 2022 January 10>. We searched grey literature by scanning 20 key national websites (e.g., Public Health Agency of Canada, UK's

Medicines \& Healthcare Products Regulatory Agency, Centers for Disease Control and Prevention) to identify unpublished data. In January, we searched L-OVE, CT.gov, Cochrane COVID Reg, WHO Covid reg, and Google Scholar for additional grey literature. We scanned reference lists of included studies and systematic reviews, and consulted our clinician authors (AM and IP) and an expert consultant (Dr. Bruce McManus; see Acknow ledgements) to identify potentially eligible studies on mechanisms. All studies/reports included in the original review were screened for eligibility for the revised questions in this update.

\section{Eligibility Criteria}

Our inclusion criteria are outlined in Table 1.

Table 1. Eligibility Criteria for Each Question

\begin{tabular}{|c|c|}
\hline Population & $\begin{array}{l}\text { People of any age; data for questions } 1 \text { and } 2 \text { must be reported using age categories } \\
\text { (e.g., } 0-4,5-11,12-17,18-29,30-39, \geq 40 \text { years) and by dose. If incidence rates w ere } \\
\text { very low and for question } 2 \text { on risk factors, w e included data across sexes if no other } \\
\text { study reported by sex. } \\
\text { Incident rates after a second dose of vaccine in Q1 w ere intended to be limited to <30 } \\
\text { year-olds; since several studies reported on an } 18-39 \text { year-old category we included } \\
\text { this data, as w ell as that for } 30-39 \text { years olds, in a post hoc manner. }\end{array}$ \\
\hline Intervention/Exposure & $\begin{array}{l}\text { Q1: mRNA vaccines approved in Canada: BNT162b2 } \\
\text { mRNA/PfizerBioNTech/Comirnaty, mRNA-1273/Maderna Spikevax (alternative } \\
\text { manufacturers of same vaccine are eligible), by type of vaccine and dose. } \\
\text { Q2: Same as KQ1, plus potential risk/protective factors: pre-existing conditions [e.g. } \\
\text { cardiac diseases, immunocompromise], previous SARS-CoV-2 infection } \\
\text { (symptomatic or asymptomatic) or other viral infections, length of vaccine dosing } \\
\text { interval, type of vaccine, vaccine combination for first vs second vs booster } \\
\text { doses. } \\
\text { Q3: Confirmed myocarditis or pericarditis after mRNA COVID-19 vaccination. For 3b } \\
\text { case did not need to be confirmed. } \\
\text { Q4: Confirmed myocarditis or pericarditis after mRNA COVID-19 vaccination. } \\
\text { Q5: Confirmed myocarditis or pericarditis after mRNA COVID-19 vaccination. } \\
\text { At least one dose of the vaccine needed to be with an mRNA vaccine; one or more } \\
\text { other doses may have been with a non-mRNA vaccine. } \\
\text { For Qs } 3-5 \text { w e included expsosure to myocarditis and/or pericarditis (combined) if there } \\
\text { w as no data on these separately. }\end{array}$ \\
\hline Control/Com parator & $\begin{array}{l}\text { Q1: People previously vaccinated with mRNA COVID-19 vaccine but no longer at risk } \\
\text { for outcome, previously vaccinated w ith other vaccines (i.e., controlling for } \\
\text { confounders associated w ith vaccine uptake), or unvaccinated people; or no } \\
\text { comparator. } \\
\text { Q2: People vaccinated w ith mRNA COVID-19 vaccine but w ithout the risk/protective } \\
\text { factor. }\end{array}$ \\
\hline
\end{tabular}


medRxiv preprint doi: https://doi.org/10.1101/2022.02.28.22271643; this version posted March 1, 2022. The copyright holder for this preprint (which was not certified by peer review) is the author/funder, who has granted medRxiv a license to display the preprint in perpetuity. It is made available under a CC-BY-NC 4.0 International license .

\begin{tabular}{|c|c|}
\hline & $\begin{array}{l}\text { Q3: No comparator. } \\
\text { Q4: No comparator, but will include data on any comparisons with people vaccinated } \\
\text { and not experiencing myocarditis or pericarditis. } \\
\text { Q5: People previously vaccinated with mRNA COVID-19 vaccine who did not } \\
\text { experience myocarditis or pericarditis; or no comparator. }\end{array}$ \\
\hline Outcome & $\begin{array}{l}\text { Q1: Incidence rate/cummulative risk of confirmed myocarditis (including } \\
\text { myopericarditis) or pericarditis by dose. Effect measures: incidence } \\
\text { rate/cummulative risk (may be risk difference if accounting for background rate in } \\
\text { control group). Will include rates of myocarditis or pericarditis (reported } \\
\text { collectively) if there are no data for these separately. } \\
\text { Q2: Ratio measures of incidence/reported events by risk/protective factor (e.g., RR or } \\
\text { odds ratios), adjusted for key confounders (e.g., previous COVID-19 illness and } \\
\text { severity) when reported. Will include rates of myocarditis or pericarditis (reported } \\
\text { collectively) if there are no data for these separately. } \\
\text { Q3: Characteristics of the patients (e.g., age, sex, pre-existing conditions [e.g., cardiac } \\
\text { diseases] and infections [e.g., recent/past SARS-CoV-2 infection], race/ethnicity) } \\
\text { and case presentation (e.g., timing/dose/type of vaccine, diagnostics, illness } \\
\text { severity, treatments provided, short-term outcomes). } \\
\text { Q4: As in Q3, plus any outcomes measured } \geq 4 \text { w eeks after onset of myocarditis or } \\
\text { pericarditis (e.g., re-hospitalization, functional capacity, chest pain). } \\
\text { Q5: Authors' summaries of any hypotheses or findings after investigating potential } \\
\text { mechanisms (e.g., histology, experiments with viral spike glycoprotein of SARS- } \\
\text { CoV-2 [encoded by mRNA vaccine]), gene panels, serology for innate and } \\
\text { acquired immune system components, autoimmune antibodies). }\end{array}$ \\
\hline Setting & Any setting and country. ${ }^{*}$ \\
\hline Study design & $\begin{array}{l}\text { Q1: Large (>10,000 vaccinated people) sample or multisite/health system-based } \\
\text { observational studies; reports or databases of confirmed case using surveillance } \\
\text { data. } \\
\text { Q2: Observational studies (including case control studies) with } n \geq 10 \text { w ith the } \\
\text { risk/protective factor; data for subset of people with myocarditis or pericarditis } \\
\text { may come from passive reporting systems. } \\
\text { Q3: Case series } n \geq 5 \text {; data may come from medical record review of cases reported to } \\
\quad \text { active or passive surveillance systems (if reporting more than age, sex, and dose } \\
\text { and type of vaccine); for Q3b we relied first on case series reported in systematic } \\
\quad \text { review s and added data on cases from more recent case series or studies } \\
\text { included for incident rates if they reported sufficient data on clinical course. } \\
\text { Q4: Case series } n \geq 5 \text {; data may come from medical record review of cases reported to } \\
\text { active or passive surveillance systems. } \\
\text { Q5: Any primary study, systematic review, or expert opinion article/letter on the topic. } \\
\text { Letters and commentaries will be included if they provide sufficient data. }\end{array}$ \\
\hline Publication Language & $\begin{array}{l}\text { English full texts. } \\
\text { We will cite those excluded based on language. }\end{array}$ \\
\hline $\begin{array}{l}\text { Publication Year \& } \\
\text { Status }\end{array}$ & $\begin{array}{l}\text { Oct } 2020-o n w \text { ards (vaccines w ere authorized mid-Sept 2020). } \\
\text { Pre-prints will be included. }\end{array}$ \\
\hline
\end{tabular}

* For questions 1 and 2, when reports collected data from similar/overlapping populations (e.g., US national surveillance data), we first included the study with the most recent data and then included additional studies if they differed in their methods (e.g., differing risk intervals [period after the vaccine where cases are counted]), differing age and/or sex stratification, use of unvaccinated or similar controls). 
medRxiv preprint doi: https://doi.org/10.1101/2022.02.28.22271643; this version posted March 1, 2022. The copyright holder for this preprint (which was not certified by peer review) is the author/funder, who has granted medRxiv a license to display the preprint in perpetuity.

It is made available under a CC-BY-NC 4.0 International license .

\section{Study Selection}

All reviewers undertaking screening conducted a pilot round in Excel using 300 records. We then conducted screening in DistillerSR (Evidence Partners) using structured forms. For title and abstract review, we applied the machine learning program Daisy AI which continually reprioritizes records during screening. ${ }^{19}$ A single reviewer screened all titles/abstracts and another reviewer verified exclusions for the first $50 \%$ of records. For full text selection, a single reviewer reviewed all records, and a second reviewer verified all exclusions. Studies were further verified for inclusion during data extraction.

For question $3 b$, we mapped the case series by country and data source to identify the most rec ent and comprehensive data source for each geographic region (i.e., US, Canada, UK, Europe, and Israel). For regions with multiple reports, we prioritized data that was most recent, most comprehensive (largest numbers), and that confirmed cases. We aimed to avoid overlap in data, i.e., the same cases reported in different sources. How ever, we did include sources that reported on specific sub-groups (e.g., 12 to 17 year-olds) to present more details on these groups of interest. We have noted in the evidence tables where there may be overlap in cases between reports and we avoided aggregating events/counts across studies.

\section{Data Extraction}

We extracted all data into structured Word forms and conducted a pilot exercise with two studies for each question. Thereafter, one reviewer extracted data and another verified study eligibility and all data. Discrepancies were resolved by discussion or by a review lead (JP or LH).

For question 1, extracted data related to all elements of the eligibility criteria (Table 1) and data used for risk of bias assessment, focusing on methods for identifying cases (i.e., passive surveillance versus active surveillance/registry data), outcome ascertainment and confirmation/adjudication (including criteria for case definitions and classification), as well as the dosing interval and risk interval for which the events were captured. We preferred estimates of incidence compared with an unexposed group (i.e., excess incidence/risk differences) over those without a control. For question 2, we extracted data as for question 1, along with associations or subgroup analyses based on pre-existing conditions, different vaccine types/products, dosing interval, and combinations of vaccines. We extracted rates in each group 
medRxiv preprint doi: https://doi.org/10.1101/2022.02.28.22271643; this version posted March 1, 2022. The copyright holder for this preprint (which was not certified by peer review) is the author/funder, who has granted medRxiv a license to display the preprint in perpetuity.

It is made available under a CC-BY-NC 4.0 International license .

and (if reported) the relative effects between groups (e.g., incidence rate ratio (IRR), odds ratios), adjusted for key confounders (i.e., infection status, cardiac and immunodeficiency/autoimmune conditions) when reported.

For questions 3 and 4, we based data extraction on the evidence table presented in an existing review ${ }^{9}$ as it covered most of the items specified under our outcomes in Table 1 . We added the following items: criteria for confirmation of cases, breakdown of cases by diagnosis (myocarditis, peric arditis, myopericarditis), case source, age included, percent with pre-existing conditions, percent admitted to an intensive care unit (ICU), perc ent hospitalized, number of fatalities. For question 4, we also added longerterm investigations and outcomes.

For question 5, we extracted verbatim authors' summaries of any hypotheses and, where available, findings by the authors or cited works investigating potential mechanisms (e.g., histology, gene panels, serology for innate and acquired immune system components, autoimmune antibodies, tissue biopsies, autopsy findings, etc.). We checked references used to support statements made by authors in proposing or explaining hypotheses to identify whether they provided direct empirical evidence (i.e., specific to COVID-19 mRNA vaccination). We involved three content experts who review ed proposed mechanisms for comprehensiveness and interpretation.

\section{Risk of Bias Assessme nt}

For questions 1 and 2, all review ers involved in the risk of bias assessments piloted the risk of bias tool with two papers. We used the JBI (formerly Joanna Briggs Institute) checklist for cohort studies, ${ }^{20}$ with modifications mainly to ascertain valid risk factor measurement (Appendix 2). We focused on valid and reliable case finding and confirmation, and, for question 2, ac counting for key confounders. Assessments were completed by one reviewer and verified by another. Discrepancies were resolved by discussion or by a review lead.

For questions 3 and 4, we did not assess the risk of bias of the included case series. The intent of these questions was to characterize these patients and their clinical course without providing quantitative estimates, e.g., of incidence. The main differentiating feature between existing case series is whether they 
medRxiv preprint doi: https://doi.org/10.1101/2022.02.28.22271643; this version posted March 1, 2022. The copyright holder for this preprint (which was not certified by peer review) is the author/funder, who has granted medRxiv a license to display the preprint in perpetuity.

It is made available under a CC-BY-NC 4.0 International license .

only report on cases confirmed/verified by clinicians; we either limited inclusion to confirmed cases

(questions $3 \mathrm{a}$ and 4 ) or extracted this information and considered this factor when summarizing the results (question 3b).

\section{Data Synthesis \& Certainty Assessments}

For question 1, we did not pool results due to heterogeneity in case finding (passive vs. active surveillance), dosing and risk intervals, age groupings, and, in some cases, some degree of overlap in cases expected between studies. We tabulated all results and compared and contrasted findings between studies based on the major differentiating population, vaccine and methodologic variables. We report the range in incidence rates across studies, or, when all rates are low, concluded that the incidence is $<20$ cases per million which, based on our clinical investigator input, we considered very rare. Based on input from clinicians and our know ledge users from PHAC we developed primary age categories $(0-4,5-11$, 12-17, 18-29) to rely on when possible. If a study contributed more than one result within these (e.g., 2024 and 25-29, results for each mRNA vaccine) we calculated a weighted average (e.g., by proportion of years in the age range) of the incident rates. When a study reported an incidence rate (or data to calculate this) and an IRR compared with a control/background rate, but not the difference in incidence (excess incidence over background rate), we calculated the exc ess incidence (i.e., crude incidence - [crude incidence/IRR]).

We assessed the certainty for each of our conclusion statements using Grading of Recommendations, Assessment, Development and Evaluation (GRADE) guidance. ${ }^{21-23}$ We did not apply a threshold for an important incidence rate, but in general considered fewer than 20 cases per million doses to be very rare. For question 2 , associations $\geq 1.5$ (odds ratio/relative risk) were considered clinically relevant (i.e., OR $<1.5$ shows "little-to-no association"). Observational studies for incident rates (question 1) started at low certainty (i.e., our confidence in the incident rate is limited; the true rate may be substantially different from the estimate) and studies on risk factors (question 2) started at high certainty $^{21}$ (i.e., we are very confident that the true difference in rate between risk groups lies close to the estimate). We rated down for serious concerns about risk of bias, inconsistency/lack of consistency 
medRxiv preprint doi: https://doi.org/10.1101/2022.02.28.22271643; this version posted March 1, 2022. The copyright holder for this preprint (which was not certified by peer review) is the author/funder, who has granted medRxiv a license to display the preprint in perpetuity.

It is made available under a CC-BY-NC 4.0 International license.

(single study), indirectness, imprecision, and/or reporting biases. We rated down for risk of bias when only studies having high risk for case asc ertainment contributed to an outcome (e.g., passive surveillance where we assume there is under-ascertainment), and for indirectness for comparisons across both sexes or if the age group reported did not match one of our groups of interest (e.g., 13-39 year olds) and the incident rates may vary substantially among ages. We rated down for imprecision in groups with fewer people than would be expected for 1 event to occur based on estimated baseline incidence rates (e.g., a subgroup with 8000 people but reporting zero events). We considered uprating due to large incidence rates (e.g., twice or more than our 20 per million threshold) when no other major limitations were evident and we had moderate confidence in our conclusion, often reported as a range of incidences. ${ }^{24}$ In our conclusions, we have used "probably", "may" and "uncertain" to reflect, respectively, moderate, low, or very low certainty evidence based on GRADE. When we have very low certainty we make no conclusions about specific incident rates or other outcomes.

For questions 3 and 4, we present the details for each case series in an evidence table and provide a descriptive summary. For question 5, we present a summary of the mechanisms and a more descriptive table.

\section{Patient and Public Involvement}

Two patient/public partners joined the research team (see Acknow ledgements). They were not involved in decisions about the questions or outcomes, which were determined by the funders. The research leads met with these partners to present and discuss the findings and their implications. The partners co-developed with the leads key messages from their perspective.

\section{Results}

\section{Study Selection}

After deduplication, our database searches on October 62021 and January 12022 retrieved 3,439 and 2,191 citations and other sources identified 18 and 805 citations. After title/abstract screening, we retrieved and screened full texts of 159 and 258 citations during each search. Forty-six studies were included in this update (Figure 1). Findings from 12 studies from the original review ${ }^{15}$ were carried 
medRxiv preprint doi: https://doi.org/10.1101/2022.02.28.22271643; this version posted March 1, 2022. The copyright holder for this preprint (which was not certified by peer review) is the author/funder, who has granted medRxiv a license to display the preprint in perpetuity.

It is made available under a CC-BY-NC 4.0 International license .

forward $\left(\mathrm{Q} 1=5{ }^{25-29}, \mathrm{Q} 2=2^{2930}, \mathrm{Q} 3 \mathrm{~b}^{25-28} 31-36\right)$. From the search update, we identified 34 new reports across all questions $\left(\mathrm{Q} 1=9^{37-45}, \mathrm{Q} 2=5^{374145-47}, \mathrm{Q} 3=1^{48}, \mathrm{Q} 4=3^{39} 49\right.$ 50, $\left.\mathrm{Q} 5=21^{951-70}\right)$; we excluded five studies that only reported on combined myo- and/or pericarditis (as we located other studies with these reported separately), ${ }^{71-75}$ eight studies that did not report on confirmed cases,${ }^{76-83}$ and three studies ${ }^{84-86}$ that did not contribute additional data to other included studies on the same cases. Tables of study characteristics, with all data on results, and risk of bias ratings for questions 1 and 2 are in Appendix 2. Appendix 3 contains descriptions of the various national surveillance systems from which reports were collated or data collected.

\section{Findings}

\section{Question 1: Incidence of Myocarditis and Pericarditis Following COVID-19 Vaccination}

We included 14 studies (reported in publications, presentations, online reports, accessible data; all are considered here as "studies" for simplicity), with 8 using active surveillance data sources (e.g., medical records/ registries) and 6 using passive reporting systems. Data came from the US, Canada, the UK, Israel, Denmark, Singapore, and internationally (Moderna Global Safety Database). Four studies used the US VAERS data source for cases, and there was overlapping populations in analyses for 5-1143 44 and $12-17^{25} 29$ year olds where two reports were included for each bec ause they applied different risk intervals (7-days and any duration). Four studies included a comparator group or background rate to estimate excess incidence rates. All studies on myocarditis reported on incident rates by age and sex; the only study reporting on peric arditis by age (5-11 year-olds) reported data across both sexes. ${ }^{39}$ Risk of bias was rated as some concerns $(\mathrm{n}=2)$ and high $(\mathrm{n}=6$, mostly from lack of adjustment for variables other than age and sex) for studies using data from active surveillance systems and high for all six studies using passive surveillance data.

Table 2 includes the results by study, the conclusions for each age and sex category, and the GRADE certainty assessments. We refer to studies by their source of adverse event data and the date of data collection; references for each study using this format are in Appendix 3.

$\underline{\text { Myocarditis after dose } 2}$ 
medRxiv preprint doi: https://doi.org/10.1101/2022.02.28.22271643; this version posted March 1, 2022. The copyright holder for this preprint (which was not certified by peer review) is the author/funder, who has granted medRxiv a license to display the preprint in perpetuity.

It is made available under a CC-BY-NC 4.0 International license .

For 5-11 year-old males and females, the incidence of myocarditis after vaccination with Pfizer may be fewer than 20 cases per million in both groups (low certainty). The incidence of myocarditis after mRNA vaccines is highest in male adolescents and young adults (12-17y: range 50-139 cases per million [low certainty] and 18-29y: range 28-147 per million [moderate certainty]). For 18-39 year-old males, the incidence of myocarditis may be between 25 and 82 cases per million (low certainty). Among females 18-29 years of age, the incidence of myocarditis after vaccination may be less than 20 cases per million (low certainty). We are very uncertain about the incidence of myocarditis after vaccination with mRNA vaccines in 12-17 year-old females, 30-39 year-old males and females, and in 18-39 year old females (very low certainty from risk of bias and inconsistency).

$\underline{\text { Myocarditis after dose } 3}$

Among $\geq 40$ year old males, the incidence of myocarditis after a third dose of an mRNA vaccines may be fewer than 20 cases per million (low certainty). For 13-39 year-old males or females and $\geq 40$ year-old females, we are unc ertain about the incidence of myocarditis after a third dose of an mRNA vac cine due to concerns about imprecision and inconsistency from multiple studies (very low certainty).

\section{$\underline{\text { Pericarditis }}$}

Based on a single study only reporting across both sexes, we are uncertain about the incidence of pericarditis after Pfizer vaccination in 5-11 year old males and females (very low certainty).

\section{Question 2. Risk Factors}

In this question, we assessed the relative differences in outcomes across subgroups. It is important to note, how ever, that these relative results must be taken in context with question 1 findings reporting on incidence; the relative differences in subgroups in females and older age groups should be given less weight in policy decision-making, based on the very low-to-no incidence of myocarditis after mRNA vaccination in these groups. Table 3 includes the results by study $(n=7)$, the conclusions for risk factor by age and (when available) sex, and the GRADE certainty assessments. We refer to studies by their source of adverse event data and the date of data collection; references for each study using this format are in

\section{Appendix 3.}


medRxiv preprint doi: https://doi.org/10.1101/2022.02.28.22271643; this version posted March 1, 2022. The copyright holder for this preprint (which was not certified by peer review) is the author/funder, who has granted medRxiv a license to display the preprint in perpetuity.

It is made available under a CC-BY-NC 4.0 International license .

\section{$\underline{\text { Myocarditis }}$}

\section{Moderna versus Pfizer, after dose 2}

For 18-29 year-old males and females, and 18-39 year-old males, the incidence of myocarditis is probably higher after vaccination with Moderna compared to Pfizer (moderate certainty). For 18-39 year-old females, the incidence of myocarditis may be higher after vaccination with Moderna compared to Pfizer (low certainty). For 30-39 year-old males and females, there may be little-to-no difference in the incidence of myocarditis after vaccination with Moderna compared to Pfizer (low certainty). Among $\geq 40$ year-old males and females, there is probably little-to-no difference in risk of myocarditis after vac cination with Moderna compared to Pfizer (moderate certainty).

Myocarditis and/or pericarditis

\section{Homologous vs heterologous vaccine for dose 2}

Among 18-29 and 18-39 year-old adults, and 18-29 year-old males, there may be little-to-no difference in the incidence of myocarditis/pericarditis after mRNA vaccination with a heterologous dose 2 (mixed Moderna and Pfizer with either for dose 2) compared to homologous dose 2 (low certainty). For adults $\geq 40$ years old, we are uncertain about any difference in the incidence of myocarditis/peric arditis after mRNA vaccination with a heterologous dose 2 compared to homologous dose 2 (very low certainty).

\section{Dose interval}

Among 12-17, 18-29 and 18-39 year-old individuals, the incidence of myocarditis/pericarditis after dose 2 of an mRNA vaccine may be lower when administered $\geq 31$ days compared to $\leq 30$ days after dose 1 (low certainty). Data specific to males aged 18-29 indicated that the dosing interval may need to increase to $\geq 56$ days to substantially drop incidence. For 18-29 year-olds, the proportional decrease in incidence of myocarditis/pericarditis after dose 2 of an mRNA vac cine when administered $\geq 31$ days compared to $\leq 30$ days after dose 1 may be similar for Moderna and Pfizer. This proportional decrease may be smaller with Moderna compared to Pfizer for 18-39 year olds (low certainty). Among $\geq 40$ year-old people, incidence of myocarditis/pericarditis after dose 2 of an mRNA vaccine may be higher when administered $\geq 31$ days compared to $\leq 30$ days after dose 1 (low certainty). In this group, the proportional increase in incidence of 
medRxiv preprint doi: https://doi.org/10.1101/2022.02.28.22271643; this version posted March 1, 2022. The copyright holder for this preprint (which was not certified by peer review) is the author/funder, who has granted medRxiv a license to display the preprint in perpetuity.

It is made available under a CC-BY-NC 4.0 International license .

myocarditis/peric arditis after dose 2 when administered $\geq 31$ days compared to $\leq 30$ days after dose 1 may be greater for Moderna compared to Pfizer.

\section{Clinical comorbidities}

We are uncertain if people with immunocompromise or inflammatory conditions have a different risk of myocarditis after mRNA vaccination (very low certainty from single studies using passive reporting systems without case confirmation and having inadequate sample sizes).

Question 3a. Case Characteristics and Short-term Clinical Course in <12 year-olds, After a Third

\section{Dose, or With Prior History of Myocarditis Following m RNA COVID-19 Vaccination}

For this update question, we included one study (also included for question 1) reporting data on 5-11 year-olds with confirmed myocarditis. ${ }^{43}$ No study was found that reported on case presentation after a third dose or for those with a previous experience of myocarditis after a COVID-19 vac cine. In a series of 5-11 year olds receiving Pfizer $(n=8), 50 \%$ were male and median age was 9 (range 6-11) years.

Race/ethnicity was not reported. Six children presented after their sec ond dose and median time to present was 3 days. Seven presented with chest pain; of six tested three had abnormal ECG findings; and of five tested one had an abnormal echocardiogram. Of six with known outcomes, five had complete resolution of symptoms. Data is presented in the last column of Table 4.

Question 3b. Case Characteristics and Short-term Clinical Course after the First or Second Dose in People of Any Age

From the original review, we report on 10 case series ( 6 published as case series ${ }^{31-36}$ and 4 included in Q1 but having relevant data on $\operatorname{cases}^{25-28}$ ) reporting on a total of 10,264 cases (median 22, range 6-5611) of myocarditis or pericarditis. All reports except the one using EudraVigilance data from the European Economic Area included clinician-confirmed cases. Table 4 (myocarditis or myopericarditis) and Table 5 (pericarditis) include data from the 10 case series. Table 4 also contains data from the case series of 5-11 year-olds included for the update question 3a.

Most case series focused on myocarditis ( 10 reports, $n=5,955)$. Across the case series, the majority of cases (often $>90 \%$ ) involved males with reported median age most often between 20 and 29 
medRxiv preprint doi: https://doi.org/10.1101/2022.02.28.22271643; this version posted March 1, 2022. The copyright holder for this preprint (which was not certified by peer review) is the author/funder, who has granted medRxiv a license to display the preprint in perpetuity.

It is made available under a CC-BY-NC 4.0 International license .

years; confirmed cases ranged from 12 to 56 years. Race/ethnicity was not reported in any case series.

Time between last vaccine and symptom onset was on average 2 to 4 days, and the majority (71-100\% across reports) presented after a second dose. Most cases presented with chest pain or pressure, and troponin elevation; when tested a minority (14-29\% across studies) showed left ventricular dysfunction (i.e., $\mathrm{LVEF}<50 \%$ ).

The majority of myocarditis cases were hospitalized ( $\geq 84 \%)$ with few admitted to ICU; average length of hospital stay was 2-4 days in four series $(\mathrm{N}=47)$ reporting on this. NSAIDs were most often used as treatment; other interventions included bisoprolol, ramipril, colchicine, famotidine, steroids (for myocarditis) and intravenous immune globulin (for myopericarditis). Among the series of confirmed cases of myocarditis that reported on fatalities $(\mathrm{N}=220)$, one fatality w as reported in Israel in a 22-yearold with fulminant myocarditis. The unconfirmed series from the EudraVigilance data reported 84 fatalities among 5,611 cases (1.5\%), though cause of death was not confirmed.

Three reports provided data for peric arditis ( $\mathrm{n}=4,309 ;>98 \%$ unconfirmed). The majority involved males; however, there was variation across reports (54 to 91\%). Median age (59 years) was only reported in one small series $(n=37)$. The same series reported a median interval of 20 days between last vaccine and symptom onset, with $60 \%$ presenting after the second vaccination. Hospitalization varied ( $35 \%$ and $73 \%$ reported in two series with a total of 59 cases); one series $(n=37)$ reported $3 \%$ admitted to ICU and 1 day for median length of stay. One series $(n=37)$ reported 0 fatalities, and a larger series of unconfirmed cases $(n=4,250)$ reported 15 deaths $(0.4 \%)$.

\section{Question 4. Longer-term outcomes}

Three reports ${ }^{394950}$ reported on 38 cases with follow-up approximately 90 days after diagnosis of myocarditis following vaccination with an mRNA COVID-19 vaccine (Table 6). Among 14 patients hospitalized for myoc arditis after vac cination in the two smaller case series $(n=14)$, patients were males aged 13-19 years and followed up for $\sim 90-105$ days after diagnosis. In the case series of five patients, ${ }^{49}$ repeat cardiac MRI was undertaken in two patients, with both showing persistent but decreased late gadolinium enhancement similar to the distribution of the initial MRI but no new abnormalities. Further, three patients had self-resolving mild 
medRxiv preprint doi: https://doi.org/10.1101/2022.02.28.22271643; this version posted March 1, 2022. The copyright holder for this preprint (which was not certified by peer review) is the author/funder, who has granted medRxiv a license to display the preprint in perpetuity.

It is made available under a CC-BY-NC 4.0 International license .

intermittent chest pain after discharge, one had recurrent chest pain after discontinuing the NSAID prescribed at discharge, and three had recurrent symptoms that prompted emergency department visits post-discharge. In the series of nine patients, ${ }^{50}$ none were on heart failure medic ation at 90 day follow-up. In the larger case series $(n=43),{ }^{39}$ among cases of myocarditis and/or peric arditis $(n=2)$ with long-term follow-up $(n=24$, mean follow-up time 89 days), the majority were males aged 12 to 17 years. Nine out of 18 patients receiving ECG had abnormal findings; 2 out of 17 with an echocardiogram showed abnormalities. Few (8\%) patients were on medications such as NSAIDs and colchicine after discharge, and $46 \%$ had no symptoms, medications, or exercise restrictions at follow-up.

\section{Question 5. Hypothesized Mechanism s}

We included 21 papers, ${ }^{951-70}$ including narrative reviews, opinion pieces, letters to the editor, case reports, case series, a retrospective study, and a protocol for a prospective observational study. Across the included papers, we identified 16 hypotheses that are presented in Table 7. Additional details for each hypothesis are available in Appendix 4. All hypotheses related to myocarditis rather than pericarditis. The most commonly discussed hypotheses were: hyper immune/inflammatory response; autoimmunity triggered by molecular mimicry or other mechanism; delayed hypersensitivity (serum sickness); eosinophilic myocarditis; and hypersensitivity to vaccine vehicle components (e.g., polyethylene glycol[PEG] and tromethamine; lipid nanoparticle sheath). A number of novel hypotheses were put forward by single papers, such as low residual levels of double-strand RNA(dsRNA), hyperviscosity inducing cardiac problems, and strenuous exercise induced secretion of proinflammatory IL-6. A number of papers discussed observed differences in incidence by sex which could be attributed to sex steroid hormones or under-diagnosis in females.

\section{Discussion}

Adolescent and young adult males are at the highest risk of myocarditis after mRNA vaccination and the incidence may be as high as 140 cases per million (1.4 per 10,000). For 5-11 year-old males and females, the incidence of myocarditis after vaccination with Pfizer may be fewer than 20 cases per million although the evidence is of low certainty. Data on incidence rates after a third vaccine dose is limited. For 18-29 year-old 
medRxiv preprint doi: https://doi.org/10.1101/2022.02.28.22271643; this version posted March 1, 2022. The copyright holder for this preprint (which was not certified by peer review) is the author/funder, who has granted medRxiv a license to display the preprint in perpetuity.

It is made available under a CC-BY-NC 4.0 International license.

males and females, incidence of myocarditis is probably higher after vaccination with Moderna compared to Pfizer (moderate certainty). Among 12-17, 18-29 and 18-39 year-olds, incidence of myocarditis/pericarditis after dose 2 of an mRNA vaccine may be lower when administered $\geq 31$ days compared to $\leq 30$ days after dose 1 (low certainty). Data specific to males aged 18-29 indicated that the dosing interval may have needed to increase to $\geq 56$ days to substantially drop incidence. Data on other potential risk factors was very limited. The clinical course of myocarditis in children 5-11 years, for those after a third dose, and for those with previous myocarditis after mRNA vaccination is largely unknown. Though the short-term course has consistently demonstrated to be quite mild and self-limiting, more data on longer-term prognosis is needed.

Several mechanisms have been hypothesized to account for COVID-19 mRNA vaccineassociated myocarditis. The hyper immune/inflammatory response hypothesis raises the question of whether the response is a systemic process or local to the heart. Multi-organ injury is commonly seen in systemic inflammation, however, a cardiac insult is easier to detect due to chest pain symptoms and measurable changes in cardiac biomarkers and imaging. While autoimmunity triggered by molecular mimicry or other mechanism is among the more commonly discussed hypothesis, the observed response timing after the second vaccine dose (1-5 days) is considered early for this type of mechanism. If mRNA vaccine related myocarditis occurs from exposure to partial antigens (epitopes of SARs-CoV2 spike protein), then this mechanism should also account for myocarditis after COVID infection. Additionally, vaccines using adenoviral vector-based platforms produce the spike protein but have not been implicated in causing higher than background rates of myocarditis. The delayed hypersensitivity hypothesis is supported by earlier work of other viruses (e.g., coxsackieviruses, echoviruses). Eosinophilic myocarditis is unlikely a major cause of post-vac cination cardiac inflammation as the rate of myocarditis would be expected to approximate the rate of true allergic reactions to the vaccine. Hypersensitivity to vaccine vehic le components is a commonly discussed hypothesis; however, this is not likely to account for a major mechanism as allergic reactions have been very rare with the vaccines. The different incidence seen across sexes also suggests a non-allergic reaction predominating. The mechanism(s) may be very similar to that for myocarditis with COVID-19 infection, but at a lower incidence due to the smaller quantity of 
medRxiv preprint doi: https://doi.org/10.1101/2022.02.28.22271643; this version posted March 1, 2022. The copyright holder for this preprint (which was not certified by peer review) is the author/funder, who has granted medRxiv a license to display the preprint in perpetuity.

It is made available under a CC-BY-NC 4.0 International license.

spike protein exposure. Therefore, exploring some of the mechanisms in the COVID-19 myocarditis literature may be valuable. One potential hypothesis that was not described in the examined articles relates to microvessel partial or complete thrombosis with multi-focal ischemic injury related to endothelial ACE2 expression and fibrin-platelet interactions in susceptible individuals.

Several limitations exist in the mechanistic literature we identified: i) little direct empiric evidence was available to support or refute the proposed hypotheses; where direct empiric evidence was available, it often derived from case reports or small series, ii) when assessing laboratory findings in case reports/series/retrospective studies, it is not clear whether any differences seen (e.g., increases in NK cells, autoantibodies) reflect a causal pathological immune response or reactive adaptive responses to the myocardial inflammation, iii) the emergence of new studies refuting some of the proposed mechanisms; for example, artic les stating no reports of eosinophilia, are out-dated due to reports finding evidence of this, iv) there has been a lack of invasive investigations (e.g., biopsy, tissue morphology, special studies to detect injury, immune activity, virus, etc.) given the typically mild course of the clinical conditions observed, and v) it is difficult to confirm a causal link; for example, an important proportion of cases observed or reported may not be vaccine-related and this will contribute to the heterogeneity of presentations, clinical characteristics, and resulting hypotheses. Choi et al. ${ }^{87}$ described a fatal case of myocarditis after mRNA vac cination and compared the case to another fatality reported by Verma et al. ${ }^{69}$ both of which had comprehensive clinicopathological analysis. The two cases were remarkably different, suggesting "that myocarditis after COVID-19 mRNA vaccination is heterogeneous, both clinically and histologically." ${ }^{17}$ Moreover, this data also supports the concept that post-COVID-19 vaccination related myocarditis can arise from different mechanisms.

Several key messages were co-developed with our patient partners to reflect their perspectives. First, the highest risk for myocarditis after COVID-19 vaccination exists for male adolescents and young adults (12-29y) although it is likely still small and occurrences appear to be quite mild with full recovery. There is probably some benefit for this population to rec eive Pfizer rather than Moderna and there may be value for dosing to be prolonged to some degree. Second, clear and effective communication 
medRxiv preprint doi: https://doi.org/10.1101/2022.02.28.22271643; this version posted March 1, 2022. The copyright holder for this preprint (which was not certified by peer review) is the author/funder, who has granted medRxiv a license to display the preprint in perpetuity.

It is made available under a CC-BY-NC 4.0 International license .

of the risks (rates of myocarditis and likely clinical course) and benefits from vaccination, and the availability of good alternatives (e.g., non-mRNA vaccines) will be critical for young males and their parents. Finally, more research on children and what personal risk factors (e.g., pre-existing conditions) may put someone at higher risk is urgently needed.

\section{Strengths and limitations of the review}

There are several strengths of this review. A comprehensive, peer-reviewed search strategy was used and inclusion of grey literature captured very recent data. A second reviewer screened the most relevant (based on machine learning) citations, and verified all data and risk of bias assessments. GRADE assessments were based on team consensus including clinical experts. Patient partners review ed the evidence and developed interpretations from the patient perspective. The main limitation is that in the era of COVID-19 the literature base is evolving with incredible rapidity and new evidence will emerge; nevertheless, there was some moderate certainty evidence found in this review. We are unaware of any other comprehensive examination, and critique, of existing descriptions of the potential mechanisms that may be involved in COVID-19 vaccine-associated myocarditis. We may have missed some mechanistic studies because of the addition of this question for this update, after the original review was completed.

\section{Conclusions}

Adolescent and young adult males are at the highest risk of myocarditis after an mRNA vaccination. Pfizer over Moderna and waiting more than 30 days between doses may be preferred for this population. As the incidence of myocarditis after mRNA vaccination remains a rare adverse event, the findings must be considered alongside the overall benefits of vac cination and with detailed risk-benefit analyses to support policy recommendations for optimal dosing intervals and vaccine products for different populations. As the COVID-19 pandemic enters its third year, continued surveillance of myocarditis after mRNA vaccines, especially in younger ages, after dose 3 (and subsequent doses) and in previous cases is needed to support continued dec ision making for COVID-19 boosters. Additional monitoring of populations with clinical comorbidities of interest (e.g., cardiac conditions, previous history 
medRxiv preprint doi: https://doi.org/10.1101/2022.02.28.22271643; this version posted March 1, 2022. The copyright holder for this preprint (which was not certified by peer review) is the author/funder, who has granted medRxiv a license to display the preprint in perpetuity. It is made available under a CC-BY-NC 4.0 International license .

of myocarditis, immunocompromised, etc.) is also needed in order to protect the already medically vulnerable. Long term follow-up of myocarditis cases is needed to better understand the natural history including disease recurrence. Finally, multi-center prospective studies with appropriate testing (e.g., biopsy, tissue morphology) will enhance understanding of the mechanism(s) of myocarditis postvaccination which in turn will help identify and guide recommendations for those who may be at higher risk.

Contributors: JP, LH, AM and IP designed the study. JP, LH, LB, LG, and AW screened citations for inclusion and were involved in data extraction and interpretation. JP, LB, LG and AW were involved is risk of bias assessments. All authors were involved in interpretation of the data. JP wrote the draft manuscript with input from all authors. All authors approved the final version of the manuscript. LH and JP are the guarantors of this manuscript and accept full responsibility for the work and the conduct of the study, had access to the data, and controlled the decision to publish. The corresponding author attests that all listed authors meet authorship criteria and that no others meeting the criteria have been omitted.

Ack nowledgements: The authors thank Dr Bruce McManus for his insight on the proposed mechanisms and the patient/public partners Linda Wilhelm (New Brunswick) and Natasha Trehan (Toronto, Ontario) for contributing key message from their perspective; Susanna Ogunnaike-Cooke and Natalia Abraham (Know ledge Users; Public Health Agency of Canada) and Dr. Andrea Tricco (Unity Health Toronto, Ontario and SPOR Evidence Alliance) for reviewing the protocol and draft report from which this article stems; and Becky Skidmore, MLS and Kaitryn Campbell, MLS, MSc (St. Joseph's Healthcare Hamilton/McMaster University) for drafting and running the searches, and for peer review ing the search strategy, respec tively.

\section{Funding Acknowledgement(s) \& Disclaimer}

This project was funded by the Canadian Institutes of Health Research (CIHR) through the COVID-19 Evidence Network to support Decision-making (COVID-END) at McMaster University and the SPOR Evidence Alliance. The funders provided input on the design of the study, but did not take part in the collection, analysis, or interpretation of data. They reviewed a report generated from the findings but did not make decisions about submission of the article for publication.

This review was developed through the analysis, interpretation and synthesis of scientific research and/or systematic reviews published in peer-review ed journals, institutional websites and other distribution channels. This document may not fully reflect all the scientific evidence available at the time this report was prepared. Other relevant scientific findings may have been reported since completion of this synthesis report.

SPOR Evidence Alliance, COVID-END and the project team at ARCHE make no warranty, express or implied, nor assume any legal liability or responsibility for the accuracy, completeness, or usefulness of any information, data, product, or process disclosed in this report. Conclusions drawn from, or actions undertaken on the basis of, information included in this report are the sole responsibility of the user. 
medRxiv preprint doi: https://doi.org/10.1101/2022.02.28.22271643; this version posted March 1, 2022. The copyright holder for this preprint (which was not certified by peer review) is the author/funder, who has granted medRxiv a license to display the preprint in perpetuity. It is made available under a CC-BY-NC 4.0 International license .

Dr. Hartling is supported by a Canada Research Chair in Knowledge Synthesis and Translation, and is a Distinguished Researcher with the Stollery Science Lab supported by the Stollery Children's Hospital Foundation.

Competing interests: All authors have completed the ICMJE uniform disclosure form at www.icmje.org/disclosure-of-interest/ and declare support from the funders for the submitted work; no financial relationships with any organisations that might have an interest in the submitted work in the previous three years; no other relationships or activities that could appear to have influenced the submitted work.

Ethics approval: This research did not involve human research participants and thus did not require ethics approval.

Transparency declaration: The lead authors of this work, JP and LH, affirm that the manuscript is an honest, ac curate, and transparent acc ount of the study being reported; that no important aspects of the study have been omitted; and that any discrepancies from the study as originally planned in the protocol have been explained.

Data sharing: All of the data extracted for this review are included in the manuscript and associated supplementary files.

\section{References}

1. Bautista García J, Peña Ortega P, Bonilla Fernández JA, Cárdenes León A, Ramírez Burgos L, Caballero Dorta E. [Acute myocarditis after administration of the BNT162b2 vaccine against COVID-19]. Rev Esp Cardiol 2021;74(9):812-4. Spanish. doi: 10.1016/j.recesp.2021.03.009

2. Israel Ministry of Health. Surveillance of Myocarditis (Inflammation of the Heart Muscle) Cases Between December 2020 and May 2021 (Including). Jun 2, 2021. Available from: https://www.gov.il/en/departments/news/01062021-03 (accessed Oct 28, 2021).

3. Marshall M, Ferguson ID, Lew is P, et al. Symptomatic Acute Myocarditis in 7 Adolescents After Pfizer-BioNTech COVID-19 Vaccination. Pediatrics 2021;148(3):e2021052478. doi: 10.1542/peds.2021-052478

4. Reuters. Israel examining heart inflammation cases in people who rec eived Pfizer COVID shot. 2021 Apr 25, 2021. Available from:https://www.reuters.com/world/middle-east/israel-examiningheart-inflammation-cases-people-who-received-pfizer-covid-shot-2021-04-25/ (acc essed Oct 28, 2021).

5. Willame C, Sturkenboom M, WeibelD. Background Rates of Adverse Events of Special Interest for Monitoring COVID-19 Vaccine. Utrect, the Netherlands; Mar 4, 2021. EU PAS register number EUPAS37273. Available from:http://www.encepp.eu/documents/DraftReport.pdf (accessed Oct 28, 2021).

6. Abara WE, Gee J, Mu Y, et al. Expected Rates of Select Adverse Events following Immunization for COVID-19 Vaccine Safety Monitoring. J Infect Dis 2021;jiab628. doi: 10.1093/infdis/jiab628

7. Gubernot D, Jazwa A, Niu M, et al. U.S. Population-Based background incidence rates of medical conditions for use in safety assessment of COVID-19 vaccines. Vaccine 2021;39(28):3666-77. doi: $10.1016 /$ j.vaccine.2021.05.016

8. Kytö V, Sipilä J, Rautava P. The effects of gender and age on oc currence of clinically suspected myocarditis in adulthood. Heart 2013;99(22):1681-4. doi: 10.1136/heartjnl-2013-304449 
medRxiv preprint doi: https://doi.org/10.1101/2022.02.28.22271643; this version posted March 1, 2022. The copyright holder for this preprint (which was not certified by peer review) is the author/funder, who has granted medRxiv a license to display the preprint in perpetuity. It is made available under a CC-BY-NC 4.0 International license .

9. Bozkurt B, Kamat I, Hotez PJ. Myocarditis With COVID-19 mRNA Vaccines. Circulation 2021;144(6):471-84. doi: 10.1161/CIRCULATIONAHA. 121.056135

10. Gargano JW, Wallace M, Hadler SC, et al. Use of mRNA COVID-19 Vaccine After Reports of Myocarditis Among Vaccine Recipients: Update from the Advisory Committee on Immunization Practices - United States, June 2021. MMWR Morb Mortal Wkly Rep 2021;70(27):977-82. doi: 10.15585/mmwr.mm7027e2

11. Cooper LT. Myocarditis. N Engl J Med 2009;360(15):1526-38. doi: 10.1056/NEJMra0800028

12. Fung G, Luo H, Qiu Y, Yang D, McManus B. Myocarditis. Circ Res 2016;118(3):496-514. doi: 10.1161/circresaha.115.306573

13. Chiabrando JG, Bonaventura A, Vecchié A, et al. Management of Acute and Recurrent Pericarditis: JACC State-of-the-Art Review. J Am Coll Cardiol 2020;75(1):76-92. doi: 10.1016/j.jacc.2019.11.021

14. Imazio M, Brucato A, Barbieri A, et al. Good prognosis for pericarditis with and without myocardial involvement: results from a multic enter, prospective cohort study. Circulation 2013;128(1):42-9. doi: 10.1161/circulationaha.113.001531

15. Pillay J, Bialy L, Gaudet L, et al. Myocarditis and Pericarditis following COVID-19 Vaccination: Rapid Systematic Review of Incidence, Risk Factors, and Clinical Course [preprint]. medRxiv 2021;2021.11.19.21266605. doi: 10.1101/2021.11.19.21266605

16. Shea BJ, Reeves BC, Wells G, et al. AMSTAR 2: a critical appraisal tool for systematic reviews that include randomised or non-randomised studies of healthcare interventions, or both. $B M J$ 2017;358:j4008. doi: 10.1136/bmj.j4008

17. Page MJ, McKenzie JE, Bossuyt PM, et al. The PRISMA 2020 statement: an updated guideline for reporting systematic reviews. $B M J 2021 ; 372: \mathrm{n} 71$. doi: 10.1136/bmj.n71

18. McGowan J, Sampson M, SalzwedelDM, Cogo E, Foerster V, Lefebvre C. PRESS Peer Review of Electronic Search Strategies: 2015 Guideline Statement. J Clin Epidemiol 2016;75:40-6. doi: 10.1016/j.jclinepi.2016.01.021

19. Hamel C, Kelly SE, Thavorn K, Rice DB, Wells GA, Hutton B. An evaluation of DistillerSR's machine learning-based prioritization tool for title/abstract screening - impact on review errelevant outcomes. BMC Med Res Methodol 2020;20(1):256. doi: 10.1186/s 12874-020-01129-1

20. Joanna Briggs Institute (JBI). Checklist for Cohort Studies 2017. Available from: https://jbi.global/sites/default/files/2019-05/JBI_Critical_AppraisalChecklist_for_Cohort_Studies2017_0.pdf(accessed Oct 21,2021)

21. Foroutan F, Guyatt G, Zuk V, et al. GRADE Guidelines 28: Use of GRADE for the assessment of evidence about prognostic factors: rating certainty in identification of groups of patients with different absolute risks. J Clin Epidemiol 2020;121:62-70. doi: 10.1016/j.jclinepi.2019.12.023

22. Guyatt GH, Oxman AD, Schunemann HJ, Tggwell P, Knottnerus A. GRADE guidelines: a new series of articles in the Journal of Clinical Epidemiology. J Clin Epidemiol 2011;64(4):380-2. doi: 10.1016/j.jclinepi.2010.09.011

23. Hultcrantz M, Rind D, Akl EA, et al. The GRADE Working Group clarifies the construct of certainty of evidence. J Clin Epidemiol 2017;87:4-13. doi: 10.1016/j.jc linepi.2017.05.006

24. Guyatt $\mathrm{GH}$, Oxman $\mathrm{AD}$, Sultan S, et al. GRADE guidelines: 9. Rating up the quality of evidence. $J$ Clin Epidemiol 2011;64(12):1311-6. doi: 10.1016/j.jclinepi.2011.06.004 
medRxiv preprint doi: https://doi.org/10.1101/2022.02.28.22271643; this version posted March 1, 2022. The copyright holder for this preprint (which was not certified by peer review) is the author/funder, who has granted medRxiv a license to display the preprint in perpetuity. It is made available under a CC-BY-NC 4.0 International license .

25. Høeg TB, Krug A, Stevenson J, Mandrola J. SARS-CoV-2 mRNA Vaccination-Associated Myocarditis in Children Ages 12-17: A Stratified National Database Analysis [preprint]. medRxiv 2021;10.1101/2021.08.30.21262866. doi: 10.1101/2021.08.30.21262866

26. Levin D, Shimon G, Fadlon-Derai M, et al. Myocarditis following COVID-19 vaccination - A case series. Vaccine 2021;39(42):6195-200. doi: 10.1016/j.vaccine.2021.09.004

27. Mevorach D, Anis E, Cedar N, et al. Myocarditis after BNT162b2 mRNA Vaccine against Covid-19 in Israel. NEngl J Med 2021;385:2140-9. doi: 10.1056/NEJMoa2109730

28. Montgomery J, Ryan M, Engler R, et al. Myocarditis Following Immunization With mRNA COVID19 Vac cines in Members of the US Military. JAMA Cardiol 2021;6(10):1202-6. doi: 10.1001/jamacardio.2021.2833

29. Su JR. Myopericarditis following COVID-19 vaccination : updates from the Vaccine Adverse Event Reporting System (VAERS). Presentation Oct 21, 2021 to U.S. Advisory Committee on Immunization Practices. CDC Stacks, 2021;ID\#110920. Available from: https://stacks.cdc.gov/view/cdc/110920 (accessed Oct 25, 2021)

30. Klein NP. Myocarditis Analysis in the Vaccine Safety Datalink: Rapid Cycle Analyses and "Head-toHead" Product Comparisons. Presentation Oct 221 to US Advisory Committee on Immunization Practic es. Presentation Oct 21, 2021 to U.S. Advisory Committee on Immunization Practices. CDC Stacks, 2021;ID\#110921. Available from:https://stacks.cdc.gov/view/cdc/110921 (accessed Oct 25, 2021)

31. Diaz GA, Parsons GT, Gering SK, Meier AR, Hutchins on I, Robicsek A. Myocarditis and Pericarditis After Vaccination for COVID-19. JAMA 2021;326(12):1210-2. doi: 10.1001/jama.2021.13443

32. Dickey JB, Albert E, Badr M, et al. A Series of Patients With Myocarditis Following SARS-CoV-2 Vaccination With mRNA-1279 and BNT162b2. JACC Cardiovasc Imaging 2021;14(9):1862-3. doi: 10.1016/j.jcmg.2021.06.003

33. European Medicines Agency. EudraVigilance - European database of suspected adverse drug reaction reports. Amsterdam, the Netherlands: European Medicines Agency; 2021. Available from: https://www.adrreports.eu/en/eudravigilance.html (accessed October 26, 2021).

34. Larson KF, Ammirati E, Adler ED, et al. Myocarditis After BNT162b2 and mRNA-1273 Vaccination. Circulation 2021;144(6):506-8. doi: 10.1161/CIRCULATIONAHA. 121.055913

35. Rosner CM, Genovese L, Tehrani BN, et al. Myocarditis Temporally Associated With COVID-19 Vaccination. Circulation 2021;144(6):502-5. doi: 10.1161/CIRCULATIONAHA. 121.055891

36. Schauer J, Buddhe S, Colyer J, et al. Myopericarditis after the Pfizer mRNA COVID-19 Vaccine in Adolescents. J Pediatr 2021;238:317-20. doi: 10.1016/j.jpeds.2021.06.083

37. Buchan SA, Seo CY, Johnson C, et al. Epidemiology of myocarditis and pericarditis following mRNA vaccines in Ontario, Canada: by vaccine product, schedule and interval [preprint]. medRxiv 2021;2021.12.02.21267156. doi: 10.1101/2021.12.02.21267156

38. Husby A, Hansen JV, Fosbol E, et al. SARS-CoV-2 vaccination and myocarditis or myopericarditis: population based cohort study. BMJ 2021;375:e068665. doi: 10.1136/bmj-2021-068665

39. Klein N. Vaccine Safety Datalink Rapid Cycle Analyses: Uptake and Safety of COVID-19 Vaccines in 5-11 and 12-17-Year-Olds. Presentation Jan 5, 2022 to U.S. Advisory Committee on Immunization Practices. Advisory Committee on Immunization Practices, 2022. Available from: https://www.cdc.gov/vaccines/acip/meetings/downloads/slides-2022-01-05/04-COVID-Klein508.pdf (accessed Jan 24, 2022). 
medRxiv preprint doi: https://doi.org/10.1101/2022.02.28.22271643; this version posted March 1, 2022. The copyright holder for this preprint (which was not certified by peer review) is the author/funder, who has granted medRxiv a license to display the preprint in perpetuity. It is made available under a CC-BY-NC 4.0 International license .

40. Niesen MJM, Paw lowski C, O'Horo JC, et al. Three doses of COVID-19 mRNA vaccination are safe based on adverse events reported in electronic health records [preprint]. medRxiv 2021;2021.11.05.21265961. doi: 10.1101/2021.11.05.21265961

41. Patone M, Mei XW, Handunnetthi L, et al. Risk of myocarditis following sequential COVID-19 vaccinations by age and sex [preprint]. medRxiv 2021;2021.12.23.21268276. doi: $10.1101 / 2021.12 .23 .21268276$

42. Straus W, Urdaneta V, Esposito DB, et al. Myocarditis after mRNA-1273 vaccination: A populationbased analysis of 151 million vaccine recipients worldwide [preprint]. medRxiv 2021;2021.11.11.21265536. doi: 10.1101/2021.11.11.21265536

43. $\mathrm{Su}$ J. Adverse events among children ages 5-11 years after COVID-19 vac cination: updates from vsafe and the Vaccine Adverse Event Reporting System (VAERS). Presentation Dec 162022 to U.S. Advisory Committee on Immunization Practices. CDC Stacks, 2021;ID\#112668. Available from: https://stacks.cdc.gov/view/cdc/112668 (accessed Jan 24, 2022)

44. Su J. COVID-19 vaccine safety updates: Primary series in children and adolescents ages 5-11 and 1215 years, and booster doses in adolescents ages 16-24 years. Presentation Jan 5, 2022 to U.S. Advisory Committee on Immunization Practices. Advisory Committee on Immunization Practices, 2022. Available from: https://www.cdc.gov/vaccines/acip/meetings/downloads/slides2022-01-05/02-COVID-Su-508.pdf (accessed Jan 24, 2022)

45. Tan JTC, Tan C, Teoh J, et al. Adverse reactions and safety profile of the mRNA COVID-19 vac cines among Asian military personnel. Ann Acad Med Singapore 2021;50(11):827-37. doi: 10.47102/annals-acadmedsg. 2021345

46. Lane S, Yeomans A, Shakir S. Systematic review of spontaneous reports of myocarditis and pericarditis in transplant recipients and immunocompromised patients following COVID-19 mRNA vaccination [preprint]. medRxiv 2021;2021.12.20.21268102. doi: $10.1101 / 2021.12 .20 .21268102$

47. Machado PM, Law son-Tovey S, Strangfeld A, et al. Safety of vac cination against SARS-CoV-2 in people with rheumatic and musculoskeletal diseases: results from the EULAR Coronavirus Vaccine (COVAX) physician-reported registry. Ann Rheum Dis 2021 (epub 2021 Dec 31).doi: 10.1136/annrheumdis-2021-221490

48. Su J. Adverse events among children ages 5-11 years after COVID-19 vac cination: updates from vsafe and the Vaccine Adverse Event Reporting System (VAERS). Presentation Dec 16, 2021 to U.S. Advisory Committee on Immunization Practices. CDC Stacks, 2021;ID\#112668. Available from: https://stacks.cdc.gov/view/cdc/112668 (accessed Jan 24, 2022)

49. Chelala L, Jeudy J, Hossain R, Rosenthal G, Pietris N, White C. Cardiac MRI Findings of Myocarditis After COVID-19 mRNA Vaccination in Adolescents. AJR Am J Roentgenol 2021 (epub 2021 Oct 27). doi: 10.2214/AJR.21.26853

50. Patel T, Kelleman M, West Z, et al. Comparison of MIS-C Related Myocarditis, Classic Viral Myocarditis, and COVID-19 Vaccine related Myocarditis in Children [preprint]. medRxiv 2021;2021.10.05.21264581. doi: 10.1101/2021.10.05.21264581

51. AbdelMassih A, El Shershaby M, Gaber H, et al. Can sarcopenia index serve as a predictor of myocarditis from mRNA based COVID-19 vaccine, insights from clustered cases and potential involvement of micro-RNAs in its pathogenesis [preprint]. Research Square 2021;rs-1036153/v2. doi: $10.21203 /$ rs.3.rs-1036153/v2 
medRxiv preprint doi: https://doi.org/10.1101/2022.02.28.22271643; this version posted March 1, 2022. The copyright holder for this preprint (which was not certified by peer review) is the author/funder, who has granted medRxiv a license to display the preprint in perpetuity. It is made available under a CC-BY-NC 4.0 International license .

52. Boursier C, Chevalier E, Filippetti L, et al. ${ }^{68}$ Ga-DOTATOC digital-PET imaging of inflammatory cell infiltrates in myocarditis following COVID-19 vaccination. Eur J Nucl Med Mol Imaging 2021 (epub 2021 Nov 8). doi: 10.1007/s00259-021-05609-4

53. Chouchana L, Blet A, Al-Khalaf M, et al. Features of Inflammatory Heart Reactions Following mRNA COVID-19 Vaccination at a Global Level. Clin Pharmacol Ther 2022;111:605-13. doi: 10.1002/cpt.2499

54. d'Angelo T, Cattafi A, Carerj ML, et al. Myocarditis After SARS-CoV-2 Vaccination: A VaccineInduced Reaction? Can J Cardiol 2021;37:1665-7. doi: 10.1016/j.cjca.2021.05.010

55. Das BB, Kohli U, Ramachandran P, et al. Myopericarditis after messenger RNA Coronavirus Disease 2019 Vaccination in Adolescents 12 to 18 Years of Age. J Pediatr 2021;238:26-32.e1. doi: 10.1016/j.jpeds.2021.07.044

56. Ehrlich P, Klingel K, Ohlmann-Knafo S, et al. Biopsy-proven lymphocytic myocarditis follow ing first mRNA COVID-19 vaccination in a 40-year-old male: case report. Clin Res Cardiol 2021;110(11):1855-9. doi: 10.1007/s00392-021-01936-6

57. Elkazzaz MR, Ghareeb A, Ahmed AK. Crosstalk among strenuous exercise, IL-6 and S-Protein Based Vaccines for COVID-19 may explain the rare adverse effects of myocarditis and thrombosis in recently vacc inated young people. A prospective observational study. Protocol Exchange 2022; pex-1744/v1. doi: 10.21203/rs.3.pex-1744/v1

58. Hajra A, Gupta M, Ghosh B, et al. Proposed Pathogenesis, Characteristics, and Management of COVID-19 mRNA Vac cine-Related Myopericarditis. Am J Cardiovasc Drugs 2022;22:9-26. doi: $10.1007 / \mathrm{s} 40256-021-00511-8$

59. Heymans S, Cooper LT. Myocarditis after COVID-19 mRNA vac cination: clinical observations and potential mechanisms. Nat Rev Cardiol 2022;19:75-7. doi: 10.1038/s41569-021-00662-w

60. Kadkhoda K. Post RNA-based COVID vaccines myocarditis: Proposed mechanisms. Vaccine 2022;40:406-7. doi: 10.1016/j.vaccine.2021.11.093

61. Kounis NG, Koniari I, Mplani V, Velissaris D, Tsigkas G. The pathogenesis of potential myocarditis induced by COVID-19 vaccine [corrected proof]. Am J Emerg Med 2021 (epub 2021 Nov 12). doi: 10.1016/j.ajem.2021.11.016

62. Kounis NG, Mplani V, Koniari I, Velissaris D. Hypersensitivity myocarditis and COVID-19 vaccines. Kardiol Pol 2022;80:109-10. doi: 10.33963/KP.a2021.0166

63. Milano G, Gal J, Creisson A, Chamorey E. Myocarditis and COVID-19 mRNA vaccines: a mechanistic hypothesis involving dsRNA. Future Virol 2021;17:191-6. doi: 10.2217/fvl-20210280

64. Parra-Lucares A, Toro L, Weitz-Munoz S, Ramos C. Cardiomyopathy Associated with Anti-SARSCoV-2 Vaccination: What Do We Know? Viruses 2021;13(12):2493. doi: 10.3390/v13122493

65. Switzer C, Loeb M. Evaluating the relationship between myocarditis and mRNA vaccination. Expert Rev Vaccines 2022;21:83-9. doi: 10.1080/14760584.2022.2002690

66. Takeda M, Ishio N, Shoji T, Mori N, Matsumoto M, Shikama N. Eosinophilic Myocarditis Following Coronavirus Disease 2019 (COVID-19) Vac cination. Circ J 2021;circj.CJ-21-0935 (epub 2021 Dec 25). doi: 10.1253/circj.CJ-21-0935

67. Truong DT, Dionne A, Muniz JC, et al. Clinically Suspected Myocarditis Temporally Related to COVID-19 Vaccination in Adolescents and Young Adults. Circulation 2022;145:345-56. doi: 10.1161/CIRCULATIONAHA. 121.056583 
medRxiv preprint doi: https://doi.org/10.1101/2022.02.28.22271643; this version posted March 1, 2022. The copyright holder for this preprint (which was not certified by peer review) is the author/funder, who has granted medRxiv a license to display the preprint in perpetuity. It is made available under a CC-BY-NC 4.0 International license .

68. Tsilingiris D, Vallianou NG, Karampela I,Liu J, Dalamaga M. Potential implications of lipid nanoparticles in the pathogenesis of myocarditis associated with the use of mRNA vaccines against SARS-CoV-2. Metabol Open 2022;13:100159 (epub 2021 Dec 17). doi: 10.1016/j.metop.2021.100159

69. Verma AK, Lavine KJ, Lin C-Y. Myocarditis after Covid-19 mRNA Vaccination. N Engl J Med 2021;385(14):1332-4. doi: 10.1056/NEJMc2109975

70. Mungmunpuntipantip R, Wiw anitkit V. Response to case report on myocarditis and pericarditis after COVID-19 vaccination. J Am Coll Emerg Physicians Open 2021;2(5):e12559 (epub 2021 Sep 27). doi: 10.1002/emp2.12559

71. Chua GT, Kwan MYW, Chui CSL, et al. Epidemiology of Acute Myocarditis/Pericarditis in Hong Kong Adolescents Following Comirnaty Vaccination. Clin Infect Dis 2021; ciab989 (epub 2021 Nov 28). doi: 10.1093/cid/ciab989

72. Farahmand R, Trottier CA, Kannam JP, Ho KKL. Incidence of Myopericarditis and Myocardial Injury in Coronavirus Disease 2019 Vaccinated Subjects. Am J Cardiol 2022;164:123-30. doi: 10.1016/j. amjc ard.2021.10.022

73. Fleming-Nouri A, Haimovich AD, Yang D, Schulz WL, Coppi A, Taylor RA. Myopericarditis in young adults presenting to the emergency department after receiving a second COVID-19 mRNA vaccine. Acad Emerg Med 2021;28(7):802-05. doi: 10.1111/acem.14307

74. Abraham N, Spruin, Rossi T, et al. Myocarditis and/or Pericarditis Risk After mRNA COVID-19 Vaccination: A Canadian Head to Head Comparison of BNT162b2 and mRNA-1273 Vaccines [preprint]. SSRN 2021;VAC-D-21-03106. Available from: https://papers.ssrn.com/sol3/papers.cfm?abstract_id=3988612 (accessed Jan 21, 2022)

75. Sharff KA, Dancoes DM, Longueil JL, Johnson ES, Lewis PF. Risk of Myopericarditis following COVID-19 mRNA vaccination in a Large Integrated Health System: A Comparison of Completeness and Timeliness of Two Methods [preprint]. medRxiv 2021;2021.12.21.21268209. doi: 10.1101/2021.12.21.21268209

76. Foltran D, Delmas C, Flumian C, et al. Myocarditis and Pericarditis in Adolescents after First and Sec ond doses of mRNA COVID-19 Vaccines. Eur Heart J Qual Care Clin Outcomes 2021;qcab090 (epub 2021 Nov 26). doi: 10.1093/ehjqcco/qcab090

77. Rosenblum HG, Gee JM, Liu R, et al. Safety Monitoring of mRNA Vaccines Administered During the Initial 6 Months of the U.S. COVID-19 Vaccination Program: Reports to Vac cine Adverse Events Reporting System (VAERS) and v-safe [preprint]. medRxiv 2021;2021.10.26.21265261. doi: $10.1101 / 2021.10 .26 .21265261$

78. Choe YJ, Yi S, Hwang I, et al. Safety and Effectiveness of BNT162b2 mRNA Covid-19 Vaccine in Adolescents. Vaccine 2022;40:691-4. doi: 10.1016/j.vaccine.2021.12.044

79. Lane S, Yeomans A, Shakir S. Reports of myocarditis and pericarditis following mRNA COVID-19 vac cines: A systematic review of spontaneously reported data from the UK, Europe, and the US and of the literature [preprint]. medRxiv 2021;2021.09.09.21263342. doi: 10.1101/2021.09.09.21263342

80. Laurent C, Alice B, Mohammad A-K, et al. Cardiac Inflammation after COVID-19 mRNA Vaccines: A Global Pharmacovigilance Analysis [preprint]. medRxiv 2021;2021.08.12.21261955. doi: 10.1101/2021.08.12.21261955

81. Li M, Yuan J, Lv G, Brown J, Jiang X, Lu ZK. Myocarditis and Pericarditis following COVID-19 Vaccination: Inequalities in Age and Vaccine Types. J Pers Med 2021;11(11):1106 (epub 2021 Oct 28). doi: 10.3390/jpm11111106 
medRxiv preprint doi: https://doi.org/10.1101/2022.02.28.22271643; this version posted March 1, 2022. The copyright holder for this preprint (which was not certified by peer review) is the author/funder, who has granted medRxiv a license to display the preprint in perpetuity.

It is made available under a CC-BY-NC 4.0 International license .

82. Pradhan PM, Shen Z, Li C, Remucal MJ. Comparison of adverse events between COVID-19 and Flu vaccines [preprint]. medRxiv 2021;2021.09.22.21263711. doi: 10.1101/2021.09.22.21263711

83. Singh A, Khillan R, Mishra Y, Khurana S. The safety profile of COVID-19 vaccinations in the United States. Am J Infect Control 2022;50(1):15-9. doi: 10.1016/j.ajic.2021.10.015

84. Hause AM, Baggs J, Marquez P, et al. COVID-19 Vaccine Safety in Children Aged 5-11 Years United States, November 3-December 19, 2021. MMWR Morb Mortal Wkly Rep 2021;70(5152):1755-60. doi: 10.15585/mmwr.mm705152a1

85. Dagan N, Barda N, Balicer RD. Adverse Effects after BNT162b2 Vaccine and SARS-CoV-2 Infection, According to Age and Sex. NEngl J Med 2021;385(24):2299. doi: 10.1056/NEJMc2115045

86. Patone M, Mei XW, Handunnetthi L, et al. Risks of myocarditis, pericarditis, and cardiac arrhythmias associated with COVID-19 vac cination or SARS-CoV-2 infection. Nat Med 2021 (epub 2021 Dec 14). doi: 10.1038/s41591-021-01630-0

87. Choi S, Lee S, Seo JW, et al. Myocarditis-induced Sudden Death after BNT162b2 mRNA COVID-19 Vaccination in Korea: Case Report Focusing on Histopathological Findings. J Korean Med Sci 2021;36(40):e286 (epub 2021 Jul 10). doi: 10.3346/jkms.2021.36.e286 
medRxiv preprint doi: https://doi.org/10.1101/2022.02.28.22271643; this version posted March 1, 2022. The copyright holder for this preprint (which was not certified by peer review) is the author/funder, who has granted medRxiv a license to display the preprint in perpetuity.

It is made available under a CC-BY-NC 4.0 International license.

Figure 1. Literature Flow from Update Search

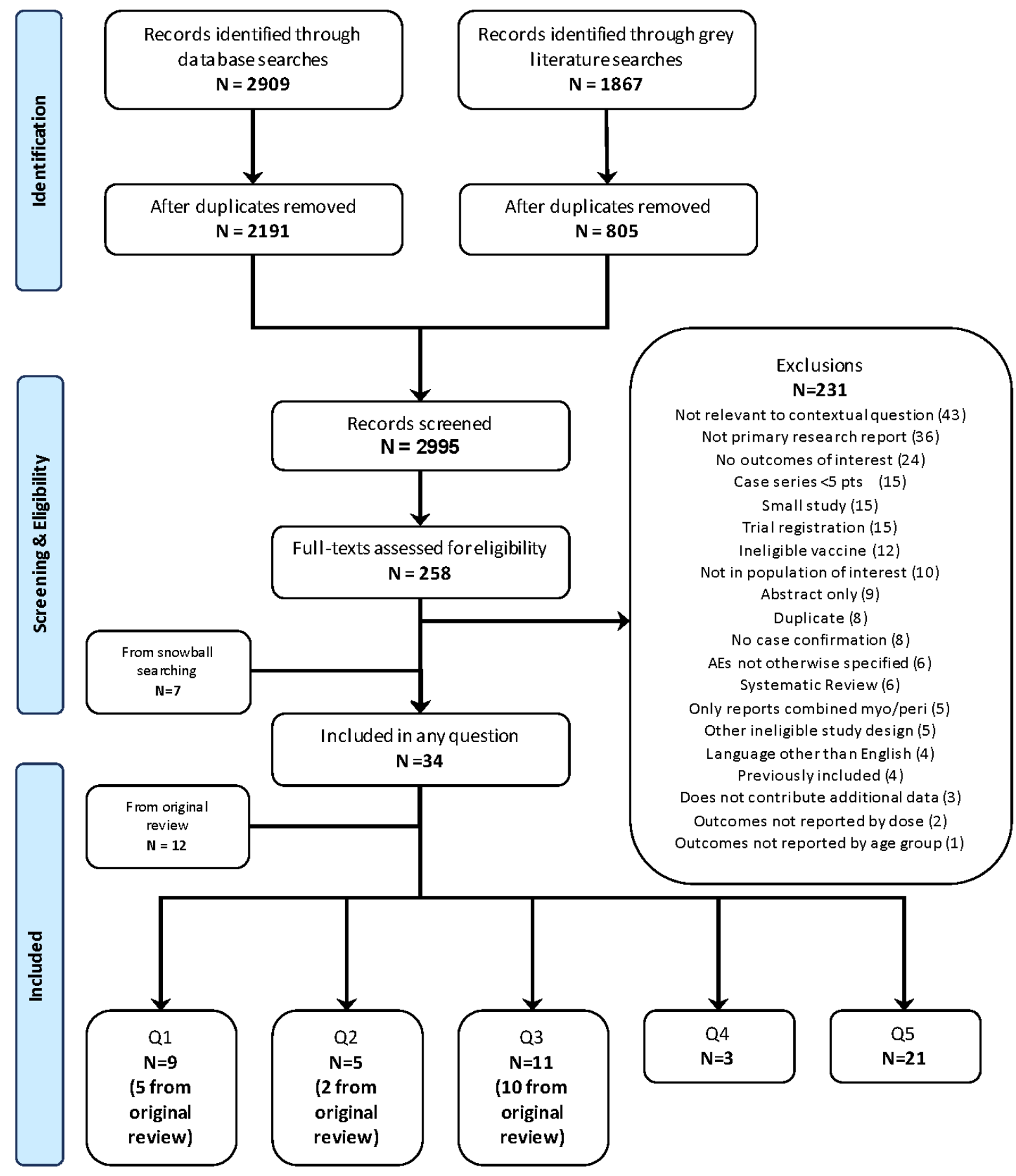


Table 2: Summary of Findings for Incident Rates after Receipt of Either mRNA Vaccine (Question 1)

\begin{tabular}{|c|c|c|c|c|c|c|}
\hline Sex & Age & $\begin{array}{l}\text { Studies (data source } \\
\text { and date) } \\
\text { Country } \\
\text { *passive surveillance } \\
\ddagger \text { some overlap in cases } \\
\text { with another source for this } \\
\text { age group }\end{array}$ & $\begin{array}{l}\text { Risk interval; } \\
\text { Confirmed cases } \\
\text { (Y/N) }\end{array}$ & $\begin{array}{l}\text { Incide nce rates per million doses } \\
\text { after dose } 2 \text { of either m RNA } \\
\text { vaccine unless otherwise stated } \\
\text { *weighted average acrossage groups } \\
\text { łweighted average across vaccine } \\
\text { products } \\
\text { †excess incidence }\end{array}$ & Conclusions & $\begin{array}{l}\text { Certainty about } \\
\text { conclusions } \\
\text { using GRADE }\end{array}$ \\
\hline \multicolumn{7}{|c|}{ Myocarditis (after dose 2) } \\
\hline \multirow[t]{18}{*}{$\mathrm{M}$} & $5-11 y$ & $\begin{array}{l}\text { VAERS* Dec } 19 \\
\text { US } \neq\end{array}$ & $7 \mathrm{~d} ; \mathrm{Y}$ & 2.3 to $4.1 †$ (Pfizer) & \multirow{3}{*}{$\begin{array}{l}\text { Among 5-11 year-oldmales, the } \\
\text { incidence of myocarditis after vaccination } \\
\text { with the Pfizer vaccine may be fewer } \\
\text { than } 20 \text { cases per million. }\end{array}$} & \multirow[t]{3}{*}{ Low } \\
\hline & & $\begin{array}{l}\text { VAERS* Dec } 9 \\
\text { US } \ddagger\end{array}$ & $12 \mathrm{~d} ; \mathrm{Y}$ & 2.98 (both sexes; Pfizer) & & \\
\hline & & $\begin{array}{l}\text { VSDDec } 30 \\
\text { US }\end{array}$ & $21 \mathrm{~d} ; \mathrm{Y}$ & $\begin{array}{l}0 \text { events (both sexes; myo or } \\
\text { pericarditis; Pfizer) }\end{array}$ & & \\
\hline & \multirow[t]{3}{*}{$12-17 y$} & $\begin{array}{l}\text { VAERS* Jun 18a } \\
\text { US } \ddagger\end{array}$ & Any; Y & $139.5^{*}$ (Pfizer) & \multirow{3}{*}{$\begin{array}{l}\text { Among } 12-17 \text { year-old males, the } \\
\text { incidence myocarditisafter vaccination } \\
\text { with the Pfizer vaccine may be between } \\
50 \text { and } 139 \text { cases per million. }\end{array}$} & \multirow[t]{3}{*}{ Low $^{\mathrm{a}, 0}$} \\
\hline & & $\begin{array}{l}\text { COVaxON* Sep } 4 \\
\text { Canada }\end{array}$ & $7 \mathrm{~d} ; \mathrm{Y}$ & 88.1 (Pfizer) & & \\
\hline & & $\begin{array}{l}\text { VAERS* Oct } 6 \\
\text { US } \ddagger\end{array}$ & $7 \mathrm{~d} ; \mathrm{Y}$ & $49.6^{*}$ (Pfizer) & & \\
\hline & $12-39 y$ & $\begin{array}{l}\text { DVR/DPR Oct } 5 \\
\text { Denmark }\end{array}$ & $14 \mathrm{~d} ; \mathrm{Y}$ & $87.7 \ddagger$ & $\begin{array}{l}\text { Among 12-39 year-old males, we are } \\
\text { uncertain about incidence of myocarditis } \\
\text { after vaccination with an mRNA vaccine. }\end{array}$ & Very Low $^{c}$ \\
\hline & \multirow[t]{6}{*}{$18-29 y$} & Singapore Military & Any; Y & $71.4^{*}$ & \multirow{6}{*}{$\begin{array}{l}\text { Among } 18-29 \text { year-old males, the } \\
\text { incidence of myocarditisafter vaccination } \\
\text { with an mRNA vaccine is probably } \\
\text { between } 28 \text { to } 147 \text { cases per million. }\end{array}$} & \multirow[t]{6}{*}{ Moderate $^{\circ}$} \\
\hline & & $\begin{array}{l}\text { COVaxON* Sep } 4 \\
\text { Canada }\end{array}$ & $7 \mathrm{~d} ; \mathrm{Y}$ & $147.2 \ddagger(18-24 y)$ & & \\
\hline & & $\begin{array}{l}\text { Tsrael Defense Forces Mar } \\
7\end{array}$ & $7 d ; Y$ & 50.7 (Pfizer; 18-24y) & & \\
\hline & & $\begin{array}{l}\text { Moderna Global Safety } \\
\text { Database* Sep } 30 \\
\text { Worldwide }\end{array}$ & $7 \mathrm{~d} ; \mathrm{Y}$ & $27.9^{*} \dagger($ Ages 18-24y; Moderna) & & \\
\hline & & $\begin{array}{l}\text { VAERS* Oct } 6 \\
\text { USA }\end{array}$ & $7 \mathrm{~d} ; \mathrm{Y}$ & $27.8^{*}$ & & \\
\hline & & Israel MOHMay 31' & $30 \mathrm{~d} ; \mathrm{Y}$ & $82.0 \dagger^{*}$ (Pfizer) & & \\
\hline & \multirow[t]{4}{*}{$18-39 y$} & Singapore Military & Any; $Y$ & $60.2^{*}$ & \multirow{4}{*}{$\begin{array}{l}\text { Among 18-39 year-old males, the } \\
\text { incidence of myocarditis after vaccination } \\
\text { with an mRNA vaccine may be between } \\
25 \text { and } 80 \text { cases per million. }\end{array}$} & \multirow[t]{4}{*}{ Low } \\
\hline & & US Military Apr 30 & 4d (all cases); Y & 44 (median 25y [IQR: 20-51y]) & & \\
\hline & & $\begin{array}{l}\text { Moderna Global Safety } \\
\text { Database* Sep } 30 \\
\text { Worldwide }\end{array}$ & $7 \mathrm{~d} ; \mathrm{Y}$ & $25.4^{*}$ (Moderna) & & \\
\hline & & $\begin{array}{l}\text { COVaxON* Sep } 4 \\
\text { Canada }\end{array}$ & $7 \mathrm{~d} ; \mathrm{Y}$ & $82.2^{*} \mp$ & & \\
\hline & $30-39 y$ & $\begin{array}{l}\text { VAERS* Oct } 6 \\
\text { US }\end{array}$ & $7 \mathrm{~d} ; \mathrm{Y}$ & $5.7 \ddagger \dagger$ & $\begin{array}{l}\text { Among 30-39 year-old males, we are } \\
\text { uncertain about the incidence of } \\
\text { myocarditisafter vaccination with an } \\
\text { mRNA vaccine. }\end{array}$ & Very Low ${ }^{a,}$ \\
\hline $\mathrm{F}$ & $5-11 y$ & $\begin{array}{l}\text { VAERS* Dec } 19 \\
\text { US } \neq\end{array}$ & $7 \mathrm{~d} ; \mathrm{Y}$ & $0-1.8 \dagger$ (Pfizer) & $\begin{array}{l}\text { Among 5-11 year-old females, the } \\
\text { incidence of myocarditis after vaccination }\end{array}$ & Low \\
\hline
\end{tabular}




\begin{tabular}{|c|c|c|c|c|c|c|}
\hline Sex & Age & $\begin{array}{l}\text { Studies (data source } \\
\text { and date) } \\
\text { Country } \\
\text { "passive surveillance } \\
\text { ‡some overlap in cases } \\
\text { with another source for this } \\
\text { age group }\end{array}$ & $\begin{array}{l}\text { Risk interval; } \\
\text { Confirmed cases } \\
\text { (Y/N) }\end{array}$ & $\begin{array}{l}\text { Incidence rates per million doses } \\
\text { after dose } 2 \text { of either } m \text { RNA } \\
\text { vaccine unless otherwise stated } \\
\text { *weighted average across age groups } \\
\text { łweighted average across vaccine } \\
\text { products } \\
\text { †excess incidence }\end{array}$ & Conclusions & $\begin{array}{l}\text { Certainty about } \\
\text { conclusions } \\
\text { using GRADE }\end{array}$ \\
\hline & & $\begin{array}{l}\text { VAERS* Dec } 9 \\
\text { US } \neq\end{array}$ & $12 \mathrm{~d} ; \mathrm{Y}$ & 2.98 (both sexes; Pfizer) & \multirow[t]{2}{*}{$\begin{array}{l}\text { with the Pfizer vaccine may be fewer } \\
\text { than } 20 \text { cases per million. }\end{array}$} & \\
\hline & & $\begin{array}{l}\text { VSDDec } 30 \\
\text { US }\end{array}$ & $21 \mathrm{~d} ; \mathrm{Y}$ & $\begin{array}{l}2.3^{*} \text { (both sexes; myo- or pericarditis; } \\
\text { Pfizer) }\end{array}$ & & \\
\hline & \multirow[t]{3}{*}{$12-17 y$} & $\begin{array}{l}\text { VAERS* Jun 18a } \\
\text { US } \ddagger\end{array}$ & Any; Y & $13.1^{*}(\mathrm{Pfizer})$ & \multirow{3}{*}{$\begin{array}{l}\text { Among 12-17 year-old females, we are } \\
\text { uncertain if the incidence of myocarditis } \\
\text { after vaccination with the Pfizer vaccine } \\
\text { is fewer than } 20 \text { cases per million. }\end{array}$} & \multirow[t]{3}{*}{ Very Low ${ }^{a}$} \\
\hline & & $\begin{array}{l}\text { COVaxON*Sep } 4 \\
\text { Canada }\end{array}$ & $7 \mathrm{~d} ; \mathrm{Y}$ & 9.7 (Pfizer) & & \\
\hline & & $\begin{array}{l}\text { VAERS* Oct } 6 \\
\text { US } \ddagger\end{array}$ & $7 \mathrm{~d} ; \mathrm{Y}$ & $5.2^{*}$ (Pfizer & & \\
\hline & \multirow[t]{4}{*}{$18-29 y$} & $\begin{array}{l}\text { VAERS* Oct } 6 \\
\text { US }\end{array}$ & $7 \mathrm{~d} ; \mathrm{Y}$ & $3.8^{*}+$ & \multirow{4}{*}{$\begin{array}{l}\text { Among 18-29 year-old females, the } \\
\text { incidence of presenting with myocarditis } \\
\text { after vaccination with an mRNA vaccine } \\
\text { may be fewer than } 20 \text { cases per million. }\end{array}$} & \multirow[t]{4}{*}{ Low } \\
\hline & & $\begin{array}{l}\text { Moderna Global Safety } \\
\text { Database* Sep } 30 \\
\text { Worldwide }\end{array}$ & $7 \mathrm{~d} ; \mathrm{Y}$ & $0^{*} \dagger($ Ages 18-24; Moderna) & & \\
\hline & & $\begin{array}{l}\text { COVaxON* Sep } 4 \\
\text { Canada }\end{array}$ & $7 \mathrm{~d} ; \mathrm{Y}$ & $34.6 \mp$ & & \\
\hline & & Israel MOHMay 31 & $30 \mathrm{~d} ; \mathrm{Y}$ & $8.97^{*}$ (16-29y; Pfizer) & & \\
\hline & \multirow[t]{2}{*}{$18-39 y$} & $\begin{array}{l}\text { COVaxON*Sep } 4 \\
\text { Canada }\end{array}$ & $7 \mathrm{~d} ; \mathrm{Y}$ & $22.8^{*} \ddagger$ & \multirow{2}{*}{$\begin{array}{l}\text { Among 18-39 year-old females, we are } \\
\text { uncertain about the incidence of } \\
\text { myocarditisafter vaccination with an } \\
\text { mRNA vaccine. }\end{array}$} & \multirow[t]{2}{*}{ Very Low $^{c}$} \\
\hline & & $\begin{array}{l}\text { Moderna Global Safety } \\
\text { Database* Sep } 30 \\
\text { Worldwide }\end{array}$ & $7 \mathrm{~d} ; \mathrm{Y}$ & $2.7^{*}$ (Moderna) & & \\
\hline & $30-39 y$ & $\begin{array}{l}\text { VAERS* Oct } 6 \\
\text { US }\end{array}$ & $7 \mathrm{~d} ; \mathrm{Y}$ & $0.6 \mp \dagger$ & $\begin{array}{l}\text { Among } 30-39 \text { year-old females, we are } \\
\text { uncertain about the incidence of } \\
\text { myocarditisafter vaccination with an } \\
\text { mRNA vaccine. }\end{array}$ & Very Low $^{a, c}$ \\
\hline \multicolumn{7}{|c|}{ Myocarditis (after dose 3) } \\
\hline \multirow[t]{4}{*}{$\mathrm{M}$} & $13-39 y$ & $\begin{array}{l}\text { NIMS/NHS Nov } 15 \\
\text { UK }\end{array}$ & $28 \mathrm{~d} ; \mathrm{Y}$ & $\begin{array}{l}13 \dagger(\text { Pfizer) } \\
0 \text { events/8,856 (Moderna) }\end{array}$ & \multirow{2}{*}{$\begin{array}{l}\text { Among 13-39 year-old males, we are } \\
\text { uncertain about the incidence of } \\
\text { myocarditis after vaccination with mRNA } \\
\text { vaccines. }\end{array}$} & \multirow[t]{2}{*}{ Very Low $^{c,}$} \\
\hline & & & $7 \mathrm{~d} ; \mathrm{Y}$ & $0 † \ddagger$ & & \\
\hline & \multirow[t]{2}{*}{$\geq 40 y$} & $\begin{array}{l}\text { NIMSINHS Nov } 15 \\
\text { UK }\end{array}$ & $28 \mathrm{~d} ; \mathrm{Y}$ & $\begin{array}{l}3+(\text { Pfizer) } \\
0 \text { events/143,066 (Moderna) }\end{array}$ & \multirow{2}{*}{$\begin{array}{l}\text { Among } \geq 40 \text { year-old males, the } \\
\text { incidence of myocarditisafter vaccination } \\
\text { with mRNA vaccines may be fewer than } \\
20 \text { cases per million. }\end{array}$} & \multirow[t]{2}{*}{ Low } \\
\hline & & & $7 \mathrm{~d} ; \mathrm{Y}$ & $0 † \ddagger$ & & \\
\hline $\bar{F}$ & $13-39 y$ & NIMS/NHS Nov 15 & $28 \mathrm{~d} ; \mathrm{Y}$ & $0 † \ddagger$ & & Very Low $^{c, 0}$ \\
\hline
\end{tabular}




\begin{tabular}{|c|c|c|c|c|c|c|}
\hline Sex & Age & $\begin{array}{l}\text { Studies (data source } \\
\text { and date) } \\
\text { Country } \\
\text { "passive surveillance } \\
\text { łsome overlap in cases } \\
\text { with another source for this } \\
\text { age group }\end{array}$ & $\begin{array}{l}\text { Risk interval; } \\
\text { Confirmed cases } \\
\text { (Y/N) }\end{array}$ & $\begin{array}{l}\text { Incidence rates per million doses } \\
\text { after dose } 2 \text { of either } m \text { RNA } \\
\text { vaccine unless otherwise stated } \\
\text { *weighted average acrossage groups } \\
\text { łweighted average acrossvaccine } \\
\text { products } \\
\text { †excess incidence }\end{array}$ & Conclusions & $\begin{array}{l}\text { Certainty about } \\
\text { conclusions } \\
\text { using GRADE }\end{array}$ \\
\hline & & UK & $7 \mathrm{~d} ; \mathrm{Y}$ & $0 † \ddagger$ & $\begin{array}{l}\text { Among 13-39 year-old females, we are } \\
\text { uncertain about the incidence of } \\
\text { myocarditis after vaccination with mRNA } \\
\text { vaccines. }\end{array}$ & \\
\hline & \multirow[t]{3}{*}{$\geq 40 y$} & \multirow{2}{*}{$\begin{array}{l}\text { NIMS/NHS Nov } 15 \\
\text { UK }\end{array}$} & $28 \mathrm{~d} ; \mathrm{Y}$ & $0 † \ddagger$ & \multirow{3}{*}{$\begin{array}{l}\text { Among } \geq 40 \text { year-old females, we are } \\
\text { uncertain about the incidence of } \\
\text { myocarditis after vaccination with mRNA } \\
\text { vaccines. }\end{array}$} & \multirow[t]{3}{*}{ Very Low $^{c, 0}$} \\
\hline & & & $7 \mathrm{~d} ; \mathrm{Y}$ & $0 \dagger \ddagger$ & & \\
\hline & & $\begin{array}{l}\text { Mayo Clinic Oct } 17 \\
\text { US }\end{array}$ & $14 \mathrm{~d} ; \mathrm{Y}$ & $41.5 \mp$ & & \\
\hline \multicolumn{7}{|c|}{ Pericarditis } \\
\hline $\mathrm{M}$ & $5-11$ & $\begin{array}{l}\text { VSD Dec } 30 \\
\text { US }\end{array}$ & $21 \mathrm{~d} ; \mathrm{Y}$ & 2.3 (both sexes; Pfizer) & $\begin{array}{l}\text { Among 5-11 year-old males, we are } \\
\text { uncertain about the incidence of } \\
\text { pericarditis after vaccination with Pfizer. }\end{array}$ & Very Low \\
\hline$F$ & $5-11$ & $\begin{array}{l}\text { VSDDec } 30 \\
\text { US }\end{array}$ & $21 d ; Y$ & 2.3 (both sexes; Pfizer) & $\begin{array}{l}\text { Among 5-11 year-old females, we are } \\
\text { uncertain about the incidence of } \\
\text { pericarditis after vaccination with Pfizer. }\end{array}$ & Very Low $^{c, e}$ \\
\hline
\end{tabular}

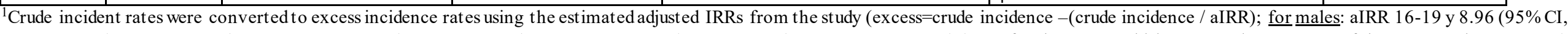

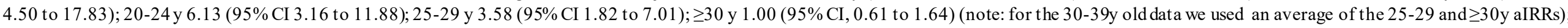
for females: $16-19$ y 2.95 (0.42-20.91), 20-24 y 7.56 (1.47-38.96), 25-29y $0, \geq 30$ y 0.82 (0.33-2.02)(not used)

\section{Explanations for GRADE:}

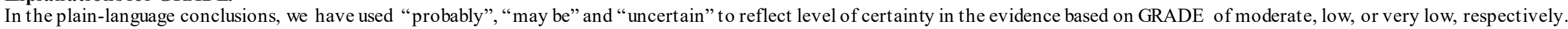

${ }^{a}$ Rated down for potential risk of bias because all data from passive reporting systems. Incidence rates may be underestimated.

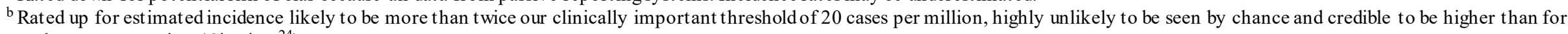
other age categories. (Citation ${ }^{24}$ )

${ }^{\mathrm{c}}$ Rated down for inconsistency for only one study or for a large incidence range within one age/sex category

${ }^{\mathrm{d}}$ Rated down for all contributing studies as being at high risk of bias

${ }^{\mathrm{e}}$ Rated down for indirectness of findings to entire population, based on large differences in estimates in analyses for males across age groups indicating one estimate (or even a range of estimates) for all ages (for both sexes or males) is not credible.

${ }^{\mathrm{f}}$ All contributing studies rated at high risk of bias, however potential biases unlikely to change conclusion so did not rate down. 
Table 3. Summary of Findings for Possible Risk Factors for Myocarditis after mRNA Vaccination (Question 2)

\begin{tabular}{|c|c|c|c|c|c|c|c|}
\hline Sex & Age & $\begin{array}{l}\text { Data source \& } \\
\text { date } \\
\text { Country } \\
\text { *passive } \\
\text { surveillance }\end{array}$ & $\begin{array}{l}\text { Risk interval; } \\
\text { confirmed } \\
\text { cases }(\mathrm{Y} / \mathrm{N})\end{array}$ & $\begin{array}{l}\text { Incidence/reporting rate per } \\
\text { million doses after dose } 2 \\
(95 \% \mathrm{Cl}) \\
{ }^{*} \text { w eighted average across multiple } \\
\text { age groups }{ }^{3}\end{array}$ & $\begin{array}{l}\text { Relative measures } \\
(95 \% \mathrm{Cl}) \\
\text { aRR = adjusted risk ratio } \\
\mathrm{RD}=\text { risk difference }\end{array}$ & Conclusions & $\begin{array}{l}\text { Certainty } \\
\text { about } \\
\text { conclusions } \\
\text { using GRADE }\end{array}$ \\
\hline \multicolumn{8}{|c|}{ Myocarditis } \\
\hline \multicolumn{8}{|c|}{ Moderna vs Pfizer (ref), dose 2} \\
\hline \multirow[t]{14}{*}{$\mathrm{M}$} & \multirow[t]{3}{*}{$18-29 y$} & VAERS Oct $6^{*}$ & $7 d ; Y$ & Moderna: $23.9^{*}$ & & \multirow{3}{*}{$\begin{array}{l}\text { Among 18-29 year-old males, } \\
\text { there is probably a higher } \\
\text { incidence of myocarditis } \\
\text { following vaccination with } \\
\text { Moderna compared with } \\
\text { Pfizer. }\end{array}$} & \multirow[t]{3}{*}{ Moderate } \\
\hline & & & & Pfizer: $26.0^{*}$ & & & \\
\hline & & $\begin{array}{l}\text { COVaxONSep } 4^{*} \\
\text { Canada }\end{array}$ & Any; Y & $\begin{array}{l}\text { Moderna: } 299.5(171.2,486.4) \\
\text { Pfizer: } 35.5(7.3,103.7)\end{array}$ & & & \\
\hline & \multirow[t]{4}{*}{$18-39$} & $\begin{array}{l}\text { VAERS Oct } 6^{*} \\
\text { US }\end{array}$ & 7d; Y & $\begin{array}{l}\text { Moderna: } 19.2^{\star} \\
\text { Pfizer: } 16.5^{*}\end{array}$ & & \multirow{4}{*}{$\begin{array}{l}\text { Among } 18-39 \text { year-old males, } \\
\text { there is probably a higher } \\
\text { incidence of myocarditis } \\
\text { following vaccination with } \\
\text { Moderna compared with } \\
\text { Pfizer. }\end{array}$} & \multirow[t]{4}{*}{ Moderate $^{c}$} \\
\hline & & $\begin{array}{l}\text { VSD Oct } 9 \\
\text { US }\end{array}$ & $7 d ; Y$ & & $\begin{array}{l}\text { RD: } 19.1 \\
\text { aRR: } 2.14 \text { (0.93 to } 4.98)\end{array}$ & & \\
\hline & & Singapore Military & Any; Y & $\begin{array}{l}\text { Moderna: } 135.3^{*} \\
\text { Pfizer: } 0 \text { events/ } 27,632\end{array}$ & & & \\
\hline & & $\begin{array}{l}\text { COVaxONSep } 4^{*} \\
\text { Canada }\end{array}$ & Any; Y & $\begin{array}{l}\text { Moderna: } 144.5^{*} \\
\text { Pfizer: } 19.9^{*}\end{array}$ & & & \\
\hline & $30-39 y$ & $\begin{array}{l}\text { VAERS Oct } 6^{*} \\
\text { US }\end{array}$ & $7 d ; Y$ & $\begin{array}{l}\text { Moderna: } 6.7 \\
\text { Pfizer: } 5.2\end{array}$ & & $\begin{array}{l}\text { Among } 30-39 \text { year-old males, } \\
\text { there may be little-to-no } \\
\text { difference in the incidence of } \\
\text { myocarditis after vaccination } \\
\text { with Moderna compared with } \\
\text { Pfizer. }\end{array}$ & Low ${ }^{c, 0}$ \\
\hline & \multirow[t]{2}{*}{$12-39 y$} & $\begin{array}{l}\text { NIMSNov } 15^{1} \\
\text { UK }\end{array}$ & $7 \mathrm{~d} ; \mathrm{Y}$ & $\begin{array}{l}\text { Moderna: IRR }=54.65(29.74,100.40) \\
\text { Pfizer: } I R R=8.05(5.37,12.06)\end{array}$ & & \multirow{2}{*}{$\begin{array}{l}\text { Among 12-39 year-old males, } \\
\text { there may be a higher } \\
\text { incidence of myocarditis } \\
\text { following vaccination with } \\
\text { Moderna compared with } \\
\text { Pfizer. }\end{array}$} & \multirow[t]{2}{*}{ Low $^{a_{1}}$} \\
\hline & & $\begin{array}{l}\text { NIMS Nov } 15^{1} \\
\text { UK }\end{array}$ & $28 \mathrm{~d} ; \mathrm{Y}$ & $\begin{array}{l}\text { Moderna: IRR = } 16.52(9.10,30.00) \\
\text { Pfizer: } I R R=3.41(2.44,4.78)\end{array}$ & & & \\
\hline & \multirow[t]{4}{*}{$\geq 40 y$} & $\begin{array}{l}\text { VAERS Oct } 6^{*} \\
\text { US }\end{array}$ & $7 d ; Y$ & $\begin{array}{l}\text { Moderna: } 1.52^{*}(40-64 y) \\
\text { Pfizer: } 0.98^{*}(40-64 y)\end{array}$ & & \multirow{4}{*}{$\begin{array}{l}\text { Among } \geq 40 \text { year-old males, } \\
\text { there is probably little-to-no } \\
\text { difference in risk of } \\
\text { myocarditis after vaccination } \\
\text { with Moderna compared with } \\
\text { Pfizer. }\end{array}$} & \multirow[t]{4}{*}{ Moderate $^{a}$} \\
\hline & & $\begin{array}{l}\text { NIMS Nov } 15^{1} \\
\text { UK }\end{array}$ & 7d; Y & $\begin{array}{l}\text { Moderna: } 0 \text { events } \\
\text { Pfizer: } \operatorname{IRR}=0.65(0.27,1.59)\end{array}$ & & & \\
\hline & & $\begin{array}{l}\text { NIMS Nov } 15^{1} \\
\text { UK }\end{array}$ & $28 d ; Y$ & $\begin{array}{l}\text { Moderna: } 0 \text { events } \\
\text { Pfizer: } \mathrm{IRR}=0.79(0.51,1.23)\end{array}$ & & & \\
\hline & & $\begin{array}{l}\text { COVaxONSep } 4^{*} \\
\text { Canada }\end{array}$ & Any; Y & $\begin{array}{l}\text { Moderna: } 0.0(0.0-35.6) \\
\text { Pfizer: } 0.0(0.0-23.3)\end{array}$ & & & \\
\hline \multirow[t]{2}{*}{$\mathrm{F}$} & \multirow[t]{2}{*}{$18-29 y$} & $\begin{array}{l}\text { COVaxONSep } 4^{*} \\
\text { Canada }\end{array}$ & Any; Y & $\begin{array}{l}\text { Moderna: } 69.1(14.2-201.9)(18-24 y) \\
\text { Pfizer: } 0.0(0.0-50.5)(18-24 y)\end{array}$ & & \multirow{2}{*}{$\begin{array}{l}\text { Among 18-29 year-old } \\
\text { females, there isprobably a } \\
\text { higher incidence of } \\
\text { myocarditisfollowing } \\
\text { vaccination with Moderna } \\
\text { compared with Pfizer. }\end{array}$} & \multirow[t]{2}{*}{ Moderate $^{a}$} \\
\hline & & $\begin{array}{l}\text { VAERS Oct } 6^{*} \\
\text { US }\end{array}$ & $7 d ; Y$ & $\begin{array}{l}\text { Moderna: } 5.5^{*} \\
\text { Pfizer: } 2.0^{*}\end{array}$ & & & \\
\hline
\end{tabular}




\begin{tabular}{|c|c|c|c|c|c|c|c|}
\hline Sex & Age & $\begin{array}{l}\text { Data source \& } \\
\text { date } \\
\text { Country } \\
\text { *passive } \\
\text { surveillance }\end{array}$ & $\begin{array}{l}\text { Risk interval; } \\
\text { confirmed } \\
\text { cases }(\mathrm{Y} / \mathrm{N})\end{array}$ & $\begin{array}{l}\text { Incidence/reporting rate per } \\
\text { million doses after dose } 2 \\
(95 \% \mathrm{Cl}) \\
{ }^{*} \text { w eighted average across multiple } \\
\text { age groups }{ }^{3}\end{array}$ & $\begin{array}{l}\text { Relative meas ures } \\
(95 \% \mathrm{Cl}) \\
\text { aRR = adjusted risk ratio } \\
\mathrm{RD}=\text { risk difference }\end{array}$ & 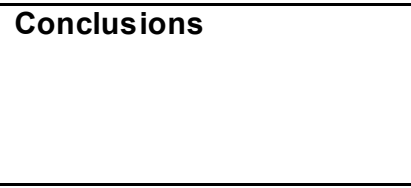 & $\begin{array}{l}\text { Certainty } \\
\text { about } \\
\text { conclusions } \\
\text { using GRADE }\end{array}$ \\
\hline & \multirow[t]{2}{*}{$18-39$} & $\begin{array}{l}\text { VAERS Oct } 6^{*} \\
\text { US }\end{array}$ & $7 \mathrm{~d} ; \mathrm{Y}$ & $\begin{array}{l}\text { Moderna: } 3.1^{*} \\
\text { Pfizer: } 1.4^{*}\end{array}$ & & \multirow{2}{*}{$\begin{array}{l}\text { Among 18-39 year-old } \\
\text { females, there may be a } \\
\text { higherincidence of } \\
\text { myocarditisfollowing } \\
\text { vaccination with Moderna } \\
\text { compared with Pfizer. }\end{array}$} & \multirow[t]{2}{*}{ Low $^{a, a}$} \\
\hline & & $\begin{array}{l}\text { COVaxONSep } 4^{*} \\
\text { Canada }\end{array}$ & Any; Y & $\begin{array}{l}\text { Moderna: } 36.8^{*} \\
\text { Pfizer: } 8.9^{*}\end{array}$ & & & \\
\hline & $30-39 y$ & $\begin{array}{l}\text { VAERS Oct } 6^{*} \\
\text { US }\end{array}$ & $7 \mathrm{~d} ; \mathrm{Y}$ & $\begin{array}{l}\text { Moderna: } 0.4 \\
\text { Pfizer: } 0.7\end{array}$ & & $\begin{array}{l}\text { Among } 30-39 \text { year-old } \\
\text { females, there may be little-to- } \\
\text { no difference in incidence of } \\
\text { myocarditisafter vaccination } \\
\text { with Moderna compared with } \\
\text { Pfizer }\end{array}$ & Low ${ }^{\text {c,a }}$ \\
\hline & \multirow[t]{2}{*}{$12-39 y$} & $\begin{array}{l}\text { NIMSNov } 15^{\top} \\
\text { UK }\end{array}$ & $7 \mathrm{~d} ; \mathrm{Y}$ & $\begin{array}{l}\text { Moderna: IRR = } 28.49(6.22,130.41) \\
\text { Pfizer: } I R R=3.11(1.23,7.86)\end{array}$ & & \multirow{2}{*}{$\begin{array}{l}\text { Among 12-39 year-old } \\
\text { females, there may be a } \\
\text { higher incidence of } \\
\text { myocarditisfollowing } \\
\text { vaccination with Moderna } \\
\text { compared with Pfizer. }\end{array}$} & \multirow[t]{2}{*}{ Low } \\
\hline & & $\begin{array}{l}\text { NIMS Nov } 15^{1} \\
\text { UK }\end{array}$ & $28 \mathrm{~d} ; \mathrm{Y}$ & $\begin{array}{l}\text { Moderna: IRR = 7.55 }(1.67,34.12) \\
\text { Pfizer: } 1.37(0.67,2.80)\end{array}$ & & & \\
\hline & \multirow[t]{4}{*}{$\geq 40 y$} & $\begin{array}{l}\text { COVaxONSep } 4^{*} \\
\text { Canada }\end{array}$ & Any; $Y$ & $\begin{array}{l}\text { Moderna: } 0.0(0.0,40.9) \\
\text { Pfizer: } 0.0(0.0,23.5)\end{array}$ & & \multirow{4}{*}{$\begin{array}{l}\text { Among } \geq 40 \text { year-old females, } \\
\text { there is probably little-to-no } \\
\text { difference in the incidence of } \\
\text { myocarditis after vaccination } \\
\text { with Moderna compared with } \\
\text { Pfizer. }\end{array}$} & \multirow[t]{4}{*}{ Moderate $^{a}$} \\
\hline & & $\begin{array}{l}\text { NIMS Nov } 15 \\
\text { UK }\end{array}$ & $7 \mathrm{~d} ; \mathrm{Y}$ & $\begin{array}{l}\text { Moderna: } 0 \text { events } \\
\text { Pfizer: IRR }=0.80(0.33,1.97)\end{array}$ & & & \\
\hline & & $\begin{array}{l}\text { NIMS Nov } 15^{1} \\
\text { UK }\end{array}$ & $28 \mathrm{~d} ; \mathrm{Y}$ & $\begin{array}{l}\text { Moderna: } 0 \text { events } \\
\text { Pfizer: IRR }=1.00(0.64,1.55)\end{array}$ & & & \\
\hline & & $\begin{array}{l}\text { VAERS Oct } 6^{*} \\
\text { US }\end{array}$ & $7 d ; Y$ & $\begin{array}{l}\text { Moderna: } 0.8^{*}(40-64 y) \\
\text { Pfizer: } 0.74^{*}(40-64 y)\end{array}$ & & & \\
\hline \multicolumn{8}{|c|}{ Myocarditis/pericarditis } \\
\hline \multicolumn{8}{|c|}{ Hom ologous vs heterologous dose 2} \\
\hline \multirow[t]{2}{*}{$\begin{array}{l}\text { Both } \\
\text { sexes }\end{array}$} & $18-29 y$ & $\begin{array}{l}\text { COVaxONSep } 4^{*} \\
\text { Canada }\end{array}$ & Any; Y & $\begin{array}{l}\text { Mod-Mod: } 162.0(108.5,232.6)(18- \\
\text { 24y) } \\
\text { Mod-Pfiz: } 0.0(0.0,218.8)(18-24 y) \\
\text { Pfiz-Mod: } 203.9(142.0,283.6)(18-24 y) \\
\text { Pfiz-Pfiz: } 26.9(14.3,45.9)(18-24 y)\end{array}$ & & $\begin{array}{l}\text { Among } 18-29 \text { year-old adults, } \\
\text { there may be little-to-no } \\
\text { difference in the incidence of } \\
\text { myocarditis after vaccination } \\
\text { with an mRNA vaccine using a } \\
\text { heterologous dose } 2 \\
\text { compared with homologous } \\
\text { dose } 2 \text {. }\end{array}$ & Low \\
\hline & $18-39 y$ & $\begin{array}{l}\text { COVaxONSep } 4^{*} \\
\text { Canada }\end{array}$ & Any; Y & $\begin{array}{l}\text { Mod-Mod: } 72.1^{*} \\
\text { Mod-Pfiz: } 0.0 \\
\text { Pfiz-Mod: } 100.3^{*} \\
\text { Pfiz-Pfiz: } 17.7^{*}\end{array}$ & & $\begin{array}{l}\text { Among 18-39 year-old adults, } \\
\text { there may be little-to-no } \\
\text { difference in the incidence of } \\
\text { myocarditis after vaccination } \\
\text { with an mRNA vaccine using a } \\
\text { heterologous dose } 2 \\
\text { compared with homologous } \\
\text { dose } 2 \text {. }\end{array}$ & Low ${ }^{a, c}$ \\
\hline
\end{tabular}




\begin{tabular}{|c|c|c|c|c|c|c|c|}
\hline Sex & Age & $\begin{array}{l}\text { Data source \& } \\
\text { date } \\
\text { Country } \\
\text { *passive } \\
\text { surveillance }\end{array}$ & $\begin{array}{l}\text { Risk interval; } \\
\text { confirmed } \\
\text { cases }(\mathrm{Y} / \mathrm{N})\end{array}$ & $\begin{array}{l}\text { Incidence/reporting rate per } \\
\text { million doses after dose } 2 \\
(95 \% \mathrm{Cl}) \\
{ }^{*} \text { W eighted average across multiple } \\
\text { age groups }{ }^{3}\end{array}$ & $\begin{array}{l}\text { Relative meas ures } \\
(95 \% \mathrm{Cl}) \\
\text { aRR = adjusted risk ratio } \\
\mathrm{RD}=\text { risk difference }\end{array}$ & Conclusions & $\begin{array}{l}\text { Certainty } \\
\text { about } \\
\text { conclusions } \\
\text { using GRADE }\end{array}$ \\
\hline & $\geq 40 y$ & $\begin{array}{l}\text { COVaxONSep } 4^{*} \\
\text { Canada }\end{array}$ & Any; $Y$ & $\begin{array}{l}\text { Mod-Mod: } 10.2(4.7,19.4) \\
\text { Mod-Pfiz: } 12.5(0.3,69.7) \\
\text { Pfiz-Mod: } 3.8(0.8,11.0) \\
\text { Pfiz-Pfiz: } 5.4(3.1,8.6)\end{array}$ & $\begin{array}{l}3.8 / 10.2 \\
12.5 / 5.4\end{array}$ & $\begin{array}{l}\text { Among } \geq 40 \text { year-old adults, } \\
\text { we are uncertain about any } \\
\text { difference in incidence of } \\
\text { myocarditis after vaccination } \\
\text { with an mRNA vaccine using } \\
\text { heterologous dose } 2 \\
\text { compared with homologous } \\
\text { dose } 2 \text {. }\end{array}$ & \begin{tabular}{|l} 
Very Low \\
\end{tabular} \\
\hline $\bar{M}$ & $18-29 y$ & $\begin{array}{l}\text { COVaxONSep } 4^{*} \\
\text { Canada }\end{array}$ & Any; Y & $\begin{array}{l}\text { Mod-Mod: } 288.4(18-24 y) \\
\text { Mod-Pfiz: } 0(18-24 y) \\
\text { Pfiz-Mod: } 337.6(18-24 y) \\
\text { Pfiz-Pfiz: } 46.6(18-24 y)\end{array}$ & & $\begin{array}{l}\text { Among } 18-29 \text { year-old males, } \\
\text { there may be little-to-no } \\
\text { difference in incidence of } \\
\text { myocarditis after vaccination } \\
\text { with an mRNA vaccine using } \\
\text { heterologous dose } 2 \text {, } \\
\text { compared with homologous } \\
\text { dose } 2 \text {. }\end{array}$ & Low $^{c, a}$ \\
\hline \multicolumn{8}{|c|}{ Dose interval } \\
\hline \multirow[t]{3}{*}{$\begin{array}{l}\text { Both } \\
\text { sexes }\end{array}$} & $12-17 y$ & $\begin{array}{l}\text { COVaxONSep } 4^{*} \\
\text { Canada }\end{array}$ & Any; $Y$ & $\begin{array}{l}<30 \text { d: } 101.9 \text { (55.7-170.9)(Pfizer only) } \\
31-55 \text { d: } 37.7 \text { (21.6-61.3) (Pfizer only) } \\
\geq 56 \text { d: } 55.7 \text { (20.4-121.2) (Pfizer only) }\end{array}$ & & $\begin{array}{l}\text { Among 12-17 year-old people, } \\
\text { incidence of myocarditisafter } \\
\text { dose } 2 \text { of an mRNA vaccine } \\
\text { may be decreased when } \\
\text { administered } \geq 31 \text { days } \\
\text { compared with administration } \\
\leq 30 \text { days after dose } 1 \text {. }\end{array}$ & Low $^{a, c}$ \\
\hline & $18-29 y$ & $\begin{array}{l}\text { COVaxONSep } 4^{*} \\
\text { Canada }\end{array}$ & Any; Y & $\begin{array}{l}<30 \mathrm{~d}: 199.2^{*}(18-24 \mathrm{y}) \\
31-55 \mathrm{~d}: 109.4^{*}(18-24 \mathrm{y}) \\
\geq 56 \mathrm{~d}: 56.7^{*}(18-24 \mathrm{y})\end{array}$ & & $\begin{array}{l}\text { Among 18-29 year-old people, } \\
\text { incidence of myocarditisafter } \\
\text { dose } 2 \text { of an mRNA vaccine } \\
\text { may be decreased when } \\
\text { administered } \geq 31 \text { days } \\
\text { compared with administration } \\
\leq 30 \text { days after dose } 1 \text {. }\end{array}$ & Low $^{a, c}$ \\
\hline & $18-39 y$ & $\begin{array}{l}\text { COVaxONSep } 4^{*} \\
\text { Canada }\end{array}$ & Any; Y & $\begin{array}{l}<30 \mathrm{~d}: 91.3^{*} \\
31-55 \mathrm{~d}: 53.1^{*} \\
\geq 56 \mathrm{~d}: 32.2^{*}\end{array}$ & & $\begin{array}{l}\text { Among 18-39 year-old people, } \\
\text { incidence of myocarditisafter } \\
\text { dose } 2 \text { of an mRNA vaccine } \\
\text { may be decreased when } \\
\text { administered } \geq 31 \text { days } \\
\text { compared with } \leq 30 \text { days after } \\
\text { dose } 1\end{array}$ & Low $^{a, c}$ \\
\hline
\end{tabular}




\begin{tabular}{|c|c|c|c|c|c|c|c|}
\hline Sex & Age & $\begin{array}{l}\text { Data source \& } \\
\text { date } \\
\text { Country } \\
\text { *passive } \\
\text { surveillance }\end{array}$ & $\begin{array}{l}\text { Risk interval; } \\
\text { confirmed } \\
\text { cases }(\mathrm{Y} / \mathrm{N})\end{array}$ & $\begin{array}{l}\text { Incidence/reporting rate per } \\
\text { m illion doses after dose } 2 \\
(95 \% \mathrm{Cl}) \\
{ }^{*} \text { W eighted average across multiple } \\
\text { age groups }{ }^{3}\end{array}$ & $\begin{array}{l}\text { Relative measures } \\
(95 \% \mathrm{Cl}) \\
\text { aRR = adjusted risk ratio } \\
\mathrm{RD}=\text { risk difference }\end{array}$ & Conclusions & $\begin{array}{l}\text { Certainty } \\
\text { about } \\
\text { conclusions } \\
\text { using GRADE }\end{array}$ \\
\hline & $\geq 40 y$ & $\begin{array}{l}\text { COVaxONSep } 4^{*} \\
\text { Canada }\end{array}$ & Any; Y & $\begin{array}{l}<30 \mathrm{~d}: 0 \\
31-55 \mathrm{~d}: 4.5 \\
\geq 56 \mathrm{~d}: 7.2\end{array}$ & & $\begin{array}{l}\text { Among } \geq 40 \text { year-old people, } \\
\text { incidence of myocarditis after } \\
\text { dose } 2 \text { of an mRNA vaccine } \\
\text { may be increased when } \\
\text { administered } \geq 31 \text { days } \\
\text { compared with } \leq 30 \text { days after } \\
\text { dose } 1 .\end{array}$ & Low $^{\mathrm{a}, \mathrm{c}}$ \\
\hline$M$ & $18-29$ & $\begin{array}{l}\text { COVaxONSep } 4^{*} \\
\text { Canada }\end{array}$ & Any; Y & $\begin{array}{l}\leq 30 \mathrm{~d}: 148.1(18-24 \mathrm{y}) \\
31-55 \mathrm{~d}: 111.1(18-24 \mathrm{y}) \\
\geq 56 \mathrm{~d}: 30.7(18-24 \mathrm{y})\end{array}$ & & $\begin{array}{l}\text { Among 18-29 year-old males, } \\
\text { incidence of myocarditisafter } \\
\text { dose } 2 \text { of an mRNA vaccine } \\
\text { may be decreased when } \\
\text { administered } \geq 56 \text { days } \\
\text { compared with } \leq 55 \text { days after } \\
\text { dose } 1 \text {. }\end{array}$ & Low $^{a, c}$ \\
\hline \multicolumn{8}{|c|}{ Dose interval, by Dose 2 product } \\
\hline & $18-29 y$ & $\begin{array}{l}\text { COVaxONSep } 4^{*} \\
\text { Canada }\end{array}$ & Any; Y & $\begin{array}{l}\text { Moderna (18-24y) } \\
<30 \mathrm{~d}: 353.1(182.4-616.8) \\
\text { 31-55d: } 184.0(133.7-247.0) \\
\geq 56 \mathrm{~d}: 103.2(44.5-203.3) \\
\text { Pfizer }(18-24 \mathrm{y}) \\
<30 \mathrm{~d}: 45.3(5.5-163.7) \\
31-55 \mathrm{~d}: 34.7-15.9-66) \\
\geq 56 \mathrm{~d}: 10.1(1.2-36.5)\end{array}$ & & $\begin{array}{l}\text { Among 18-29 year old people, } \\
\text { the proportional decrease in } \\
\text { incidence of myocarditisafter } \\
\text { dose } 2 \text { of an mRNA vaccine } \\
\text { when administered } \geq 31 \text { days } \\
\text { compared with } \leq 30 \text { days after } \\
\text { dose } 1 \text { may be similar for } \\
\text { Moderna compared with } \\
\text { Pfizer. }\end{array}$ & Low $^{a, c}$ \\
\hline & $18-39 y$ & $\begin{array}{l}\text { COVaxONSep } 4^{*} \\
\text { Canada }\end{array}$ & Any; Y & $\begin{array}{l}\text { Moderna } \\
<30 \mathrm{~d}: 139.3^{*} \\
31-55 \mathrm{~d}: 89.2^{*} \\
\geq 56 \mathrm{~d}: 52.9 \\
\frac{\text { Pfizer }}{<30 \mathrm{~d}: 43.4^{*}} \\
31-55 \mathrm{~d}: 17.0^{*} \\
\geq 56 \mathrm{~d}: 11.6^{*}\end{array}$ & & $\begin{array}{l}\text { Among 18-39 year-old people, } \\
\text { the proportional decrease in } \\
\text { incidence of myocarditisafter } \\
\text { dose } 2 \text { of an mRNA vaccine } \\
\text { when administered } \geq 31 \text { days } \\
\text { compared with } \leq 30 \text { daysafter } \\
\text { dose } 1 \text { may be smaller in } \\
\text { Moderna compared with } \\
\text { Pfizer. }\end{array}$ & Low $^{a, c}$ \\
\hline & $\geq 40 y$ & $\begin{array}{l}\text { COVaxONSep } 4^{*} \\
\text { Canada }\end{array}$ & Any; Y & $\begin{array}{l}\frac{\text { Moderna }}{<30 d: 0.0}(0.0-53.9) \\
\text { 31-55d: } 7.4(2.0-19.0) \\
\text { 56d: } 7.5(3.2-14.7) \\
\frac{\text { Pfizer }}{<30 d: 0.0(0.0-34.4)} \\
\text { 31-55d: } 1.5(0.0-8.3) \\
\text { 56d: } 6.9(4.0-11.1)\end{array}$ & & $\begin{array}{l}\text { Among } \geq 40 \text { year-old people, } \\
\text { the proportional increase in } \\
\text { incidence of myocarditisafter } \\
\text { dose } 2 \text { of an mRNA vaccine } \\
\text { when administered } \geq 31 \text { days } \\
\text { compared with } \leq 30 \text { daysafter } \\
\text { dose } 1 \text { may be greater for } \\
\text { Moderna compared with } \\
\text { Pfizer. }\end{array}$ & Low $^{a, c}$ \\
\hline
\end{tabular}




\begin{tabular}{|c|c|c|c|c|c|c|c|}
\hline Sex & Age & $\begin{array}{l}\text { Data source \& } \\
\text { date } \\
\text { Country } \\
\text { *passive } \\
\text { surveillance }\end{array}$ & $\begin{array}{l}\text { Risk interval; } \\
\text { confirmed } \\
\text { cases }(\mathrm{Y} / \mathrm{N})\end{array}$ & $\begin{array}{l}\text { Incidence/reporting rate per } \\
\text { million doses after dose } 2 \\
(95 \% \mathrm{Cl}) \\
{ }^{*} \text { w eighted average across multiple } \\
\text { age groups }{ }^{3}\end{array}$ & $\begin{array}{l}\text { Relative measures } \\
(95 \% \mathrm{Cl}) \\
\text { aRR = adjusted risk ratio } \\
\mathrm{RD}=\text { risk difference }\end{array}$ & Conclusions & $\begin{array}{l}\text { Certainty } \\
\text { about } \\
\text { conclusions } \\
\text { using GRADE }\end{array}$ \\
\hline \multirow[t]{2}{*}{$\begin{array}{l}\text { Both } \\
\text { sexes }\end{array}$} & \multirow[t]{2}{*}{ All ages } & $\begin{array}{l}\text { EULAR COVAX* } \\
\text { Europe }\end{array}$ & Any; N & \multicolumn{2}{|c|}{$\begin{array}{l}\text { Among } 4025 \text { people with inflammatory rheumatic musculoskeletal } \\
\text { conditions }(68 \% \text { female) who received at least one dose of mRNA } \\
\text { vaccine, there was one event in a young }(<30 y) \text { female after dose } 2 \text { of } \\
\text { Pfizer. There were no eventsin } 412 \text { people with non-inflammatory } \\
\text { rheumatic musculoskeletal conditions who received at least one dose of } \\
\text { mRNA vaccine. }\end{array}$} & $\begin{array}{l}\text { We are uncertain if individuals } \\
\text { with inflammatory conditions } \\
\text { have increased risk of } \\
\text { myocarditis after mRNA } \\
\text { vaccination. }\end{array}$ & Very Low ${ }^{0, c, 0}$ \\
\hline & & $\begin{array}{l}\text { VAERS Nov } 30^{*} \\
\text { USA }\end{array}$ & Any; $N$ & \multicolumn{2}{|c|}{$\begin{array}{l}\text { The reporting rate of myocarditis/pericarditis washigher for } \\
\text { immunocompromised patients compared with immune competent } \\
\text { individuals (Proportional reporting rate }=1.36[95 \% \mathrm{Cl}: 0.89-1.82] \text { ). }\end{array}$} & $\begin{array}{l}\text { We are uncertain if individuals } \\
\text { with immunocompromise have } \\
\text { increased risk of myocarditis } \\
\text { after mRNA vaccination. }\end{array}$ & Very Low $^{0, C}$ \\
\hline
\end{tabular}

${ }^{1}$ This study reported IRRs calculated using a self-controlled case series design. In this study design, individuals serve as their own controls and risk estimates in pre- and post-intervention intervals are calculated within individuals, rather than across individuals.

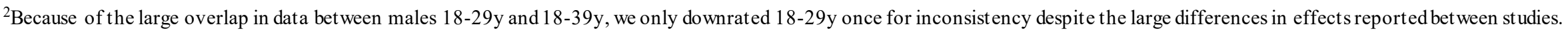

${ }^{3}$ Weighted averages across age groups were calculated based on contribution of each age to the review-level age category.

\section{Explanations for GRADE}

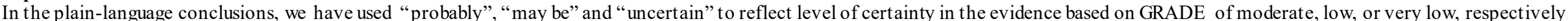

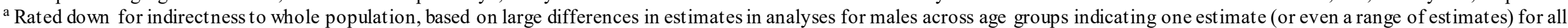
ages (for both sexes or males) is not credible.

${ }^{b}$ Rated down for risk of bias from use of passive surveillance and lack of case verification

${ }^{c}$ Rated down for inconsistency due to only one study providing estimates

${ }^{\mathrm{d}}$ Rated down for imprecision for small sample size $(<10,000$ per group) or very low event rate.

Table 4. Results from Case Series with Short-term Follow-up of Myocarditis and Myopericarditis after COVID-19 Vaccination (Question 3a and b)

\begin{tabular}{|c|c|c|c|c|c|c|c|c|c|c|c|}
\hline $\begin{array}{l}\text { Case series } \\
\text { (Country) }\end{array}$ & $\begin{array}{l}\text { Dickey 2021* } \\
\text { (US) }\end{array}$ & $\begin{array}{l}\text { Diaz } 2021 \\
\text { (US) }\end{array}$ & $\begin{array}{l}\text { Hoeg } 2021^{*} \\
\text { (US) }\end{array}$ & $\begin{array}{l}\text { Montgomery } \\
2021 \\
\text { (US) }\end{array}$ & $\begin{array}{l}\text { Rosner } 2021 \\
\text { (US) }\end{array}$ & $\begin{array}{l}\text { Larson } 2021 \\
\text { (Italy \& US) }\end{array}$ & $\begin{array}{l}\text { Mevorach } 2021 \\
\text { (Israel) }\end{array}$ & $\begin{array}{l}\text { Levin } 2021 \\
\text { (Israel) }\end{array}$ & $\begin{array}{l}\text { EudraVigilance } \\
\text { (European } \\
\text { Economic } \\
\text { Area) }\end{array}$ & $\begin{array}{l}\text { Schauer 2021 } \\
\text { (US) }\end{array}$ & $\begin{array}{l}\text { Su } 2021 \\
\text { (US) }\end{array}$ \\
\hline $\begin{array}{l}\text { Date of cases } \\
\text { last updated }\end{array}$ & Sep 2021 & 25 May 2021 & 18 Jun 2021 & 30 Apr 2021 & $\begin{array}{l}10 \text { Aug } 2021 \\
\text { (publication } \\
\text { date) }\end{array}$ & $\begin{array}{l}10 \text { Aug } 2021 \\
\text { (date published) }\end{array}$ & 31 May 2021 & 1 Mar 2021 & 25 Oct 2021 & 21 Jun 2021 & $10 \mathrm{Dec} 2021$ \\
\hline \multirow{2}{*}{$\begin{array}{l}\text { Cases of } \\
\text { my ocarditis, } n \\
\text { Confirmed } \\
\text { cases }\end{array}$} & 6 & 20 & 124 & 23 & 7 & 8 & 136 & 7 & 5611 & 13 & 8 \\
\hline & $\begin{array}{l}\text { All CMR-proven } \\
\text { my ocarditis }\end{array}$ & $\begin{array}{l}\text { Clinically } \\
\text { conf irmed with } \\
\text { troponin values } \\
\text { or cardiac MRI }\end{array}$ & $\begin{array}{l}\text { Inclusion criteria } \\
\text { aligned with } \\
\text { CDC working } \\
\text { case definition } \\
\text { for probable } \\
\text { myocarditis, } \\
\text { pericarditis, or } \\
\text { my opericarditis }\end{array}$ & $\begin{array}{l}\text { Diagnoses } \\
\text { reviewed and } \\
\text { met the CDC } \\
\text { case definition } \\
\text { criteria for } \\
\text { probable } \\
\text { my ocarditis }\end{array}$ & $\begin{array}{l}\text { Confirmed via } \\
\text { diagnostic } \\
\text { testing }\end{array}$ & $\begin{array}{l}\text { Diagnosed with } \\
\text { my ocarditis by } \\
\text { laboratory and } \\
\text { cardiac MRI }\end{array}$ & $\begin{array}{l}\text { Brighton } \\
\text { Collaboration } \\
\text { case def inition of } \\
\text { my ocarditis or } \\
\text { my opericarditis }\end{array}$ & $\begin{array}{l}\text { Based on clinical } \\
\text { records }\end{array}$ & $\begin{array}{l}\text { Reported by } \\
\text { healthcare or } \\
\text { non-healthcare } \\
\text { prof essionals }\end{array}$ & $\begin{array}{l}\text { All CMR-proven } \\
\text { myopericarditis }\end{array}$ & $\begin{array}{l}\text { Diagnoses } \\
\text { reviewed and } \\
\text { met the CDC } \\
\text { case def inition }\end{array}$ \\
\hline
\end{tabular}




\begin{tabular}{|c|c|c|c|c|c|c|c|c|c|c|c|}
\hline $\begin{array}{l}\text { Case series } \\
\text { (Country) }\end{array}$ & $\begin{array}{l}\text { Dickey 2021* } \\
\text { (US) }\end{array}$ & $\begin{array}{l}\text { Diaz } 2021 \\
\text { (US) }\end{array}$ & $\begin{array}{l}\text { Hoeg 2021* } \\
\text { (US) }\end{array}$ & $\begin{array}{l}\text { Montgomery } \\
2021 \\
\text { (US) }\end{array}$ & \begin{tabular}{|l|}
$\begin{array}{l}\text { Rosner } 2021 \\
\text { (US) }\end{array}$ \\
\end{tabular} & $\begin{array}{l}\text { Larson } 2021 \\
\text { (Italy \& US) }\end{array}$ & $\begin{array}{l}\text { Mevorach } 2021 \\
\text { (Israel) }\end{array}$ & $\begin{array}{l}\text { Levin } 2021 \\
\text { (Israel) }\end{array}$ & $\begin{array}{l}\text { EudraVigilance } \\
\text { (European } \\
\text { Economic } \\
\text { Area) }\end{array}$ & $\begin{array}{l}\text { Schauer 2021* } \\
\text { (US) }\end{array}$ & $\begin{array}{l}\text { Su } 2021 \\
\text { (US) }\end{array}$ \\
\hline Case source & $\begin{array}{l}\text { Univ ersity of } \\
\text { Massachusetts } \\
\text { Memorial Health }\end{array}$ & $\begin{array}{l}40 \text { hospitals that } \\
\text { were part of } \\
\text { Providence } \\
\text { health care } \\
\text { system and use } \\
\text { same electronic } \\
\text { medical record } \\
\text { (Washington, } \\
\text { Oregon, } \\
\text { Montana, Los } \\
\text { Angeles County, } \\
\text { Calif ornia) }\end{array}$ & VAERS & $\begin{array}{l}\text { USTMilitary } \\
\text { Health Sy stem }\end{array}$ & $\begin{array}{l}\text { Two US medical } \\
\text { centers in Falls } \\
\text { Church, Virginia, } \\
\text { and Dallas, } \\
\text { Texas }\end{array}$ & $\begin{array}{l}\text { Hospitalized } \\
\text { patients in Italy } \\
\text { and USA }\end{array}$ & TsraeliMOH & $\begin{array}{l}\text { Hospitalized } \\
\text { patients in Israeli } \\
\text { Def ense Forces } \\
\text { Medical Corps }\end{array}$ & Eudravigilance & $\begin{array}{l}\text { Seattle } \\
\text { Children's } \\
\text { Hospital }\end{array}$ & VAERS \\
\hline Male, $n$ & $6(100 \%)$ & $15(75 \%)$ & $113(91 \%)$ & $23(100 \%)$ & $7(100 \%)$ & $8(100 \%)$ & $118(87 \%)$ & $7(100 \%)$ & $4040(72 \%)$ & $12(92 \%)$ & $4(50 \%)$ \\
\hline $\begin{array}{l}\text { Median age } \\
\text { (range), y }\end{array}$ & NR (17-37) & $36(26.3-48.3)$ & NR (12-17) & $25(20-51)$ & $24(19-30)$ & $29(21-56)$ & $\begin{array}{l}\text { NR ( } 76 \% \text { under } \\
\text { the age of } 30)\end{array}$ & $20(18-24)$ & $\overline{N R}$ & $15(12-17)$ & $9(6-11)$ \\
\hline Ages included & $\begin{array}{l}\text { All ages } \\
\text { included }\end{array}$ & $\begin{array}{l}\text { All ages } \\
\text { included }\end{array}$ & $\begin{array}{l}\text { Search limited to } \\
12-17 \text { y ears }\end{array}$ & $\begin{array}{l}\text { All ages } \\
\text { included }\end{array}$ & $\begin{array}{l}\text { All ages } \\
\text { included }\end{array}$ & $\begin{array}{l}\text { All ages } \\
\text { included }\end{array}$ & $\begin{array}{l}\text { All ages } \\
\text { included }\end{array}$ & $\begin{array}{l}\text { All ages } \\
\text { included }\end{array}$ & $\begin{array}{l}\text { All ages } \\
\text { included }\end{array}$ & $\begin{array}{l}\text { Search limited to } \\
12-17 \text { y ears }\end{array}$ & $5-11$ y ears \\
\hline $\begin{array}{l}\text { Patients with } \\
\text { pre-existing } \\
\text { conditions } \\
\text { (excluding } \\
\text { prior COVID- } \\
19 \text { inf ection, } \\
\text { see below) }\end{array}$ & $\begin{array}{l}\text { All patients were } \\
\text { prev iously } \\
\text { healthy }\end{array}$ & $\begin{array}{l}\text { Alcohol or drug } \\
\text { dependence = } 4 \\
(20 \%) ; \\
\text { coronary artery } \\
\text { disease = } 1 \\
(5 \%) ; \\
\text { cancer = } 2 \\
(10 \%) ; \\
\text { heart failure = } 0 \text {; } \\
\text { cirrhosis =0; } \\
\text { chronic kidney } \\
\text { disease = } 1 \\
(5 \%) ; \\
\text { COPD = } 0 ; \\
\text { diabetes }=2 \\
(10 \%) ; \\
\text { hy pertension = } 5 \\
(25 \%) ; \\
\text { autoimmune } \\
\text { disease = } 0\end{array}$ & NR & $\begin{array}{l}\text { Patients had no } \\
\text { history of } \\
\text { cardiac disease, } \\
\text { signif icant } \\
\text { cardiac risk } \\
\text { factors, or } \\
\text { exposure to } \\
\text { cardiotoxic } \\
\text { agents }\end{array}$ & $\begin{array}{l}\text { No patients had } \\
\text { evidence of an } \\
\text { autoimmune } \\
\text { disease }\end{array}$ & $\begin{array}{l}\text { All patients were } \\
\text { otherwise } \\
\text { healthy }\end{array}$ & $\mathrm{NR}$ & $\begin{array}{l}\text { ADHD = 1 } \\
(14 \%) ; \\
\text { allergic asthma } \\
=11(4 \%) ; \\
\text { celiac disease = } \\
1(14 \%) ; \\
\text { my ocarditis } 5 \\
\text { y ears earlier =1 } \\
(14 \%) ; \\
\text { none = } 3(43 \%)\end{array}$ & NR & $\begin{array}{l}2(15 \%) \text { had } \\
\text { history of } \\
\text { my ocarditis in } \\
\text { first degree } \\
\text { relative }\end{array}$ & NR \\
\hline $\begin{array}{l}\text { Patients with } \\
\text { prior COVID- } \\
19 \text { history }\end{array}$ & 0 & NR & NR & $3(13 \%)$ & $1(14 \%)$ & $2(25 \%)$ & 0 & 0 & NR & NR & NR \\
\hline $\begin{array}{l}\text { Vaccine type, } \\
\text { n }\end{array}$ & $\begin{array}{l}5(83 \%)= \\
\text { BNT162b2 } \\
\text { (Pfizer) } \\
1(17 \%)= \\
\text { mRNA-1273 } \\
\text { (Moderna) }\end{array}$ & $\begin{array}{l}9(45 \%)= \\
\text { BNT162b2 } \\
\text { (Pfizer) } \\
11(55 \%)= \\
\text { mRNA-1273 } \\
\text { (Moderna) }\end{array}$ & $\begin{array}{l}146(100 \%)= \\
\text { BNT162b2 } \\
\text { (Pfizer) }\end{array}$ & $\begin{array}{l}7(30 \%)=\text { BNT } \\
162 \mathrm{~b} 2 \\
\text { (Pfizer) } \\
16(70 \%)= \\
\text { mRNA1273 } \\
\text { (Moderna) }\end{array}$ & $\begin{array}{l}5(71 \%)= \\
\text { BNT162b2 } \\
\text { (Pfizer) } \\
1(14 \%)= \\
\text { mRNA-1273 } \\
\text { (Moderna) } \\
1(14 \%)=\mathrm{J} \& \mathrm{~J}\end{array}$ & $\begin{array}{l}5(63 \%)=B N T \\
162 \mathrm{~b} 2 \\
\text { (Pfizer) } \\
3(37 \%)= \\
\text { mRNA1273 } \\
\text { (Moderna) }\end{array}$ & $\begin{array}{l}136(100 \%)= \\
\text { BNT 162b2 } \\
\text { (Pfizer) }\end{array}$ & $\begin{array}{l}7(100 \%)=\mathrm{BNT} \\
162 \mathrm{~b} 2 \text { (Pf izer) }\end{array}$ & $\begin{array}{l}3610(64 \%)= \\
\text { BNT162b2 } \\
\text { (Pfizer) } \\
1578(28 \%)= \\
\text { mRNA-1273 } \\
\text { (Moderna) } \\
320(6 \%)= \\
\text { AZD1222 } \\
\text { (AstraZeneca) }\end{array}$ & $\begin{array}{l}13(100 \%)= \\
\text { BNT162b2 } \\
\text { (Pfizer) }\end{array}$ & $\begin{array}{l}8(100 \%)= \\
\text { BNT162b2 } \\
\text { (Pfizer) }\end{array}$ \\
\hline
\end{tabular}




\begin{tabular}{|c|c|c|c|c|c|c|c|c|c|c|c|}
\hline $\begin{array}{l}\text { Case series } \\
\text { (Country) }\end{array}$ & $\begin{array}{l}\text { Dickey 2021* } \\
\text { (US) }\end{array}$ & \begin{tabular}{|l|}
$\begin{array}{l}\text { Diaz } 2021 \\
\text { (US) }\end{array}$ \\
\end{tabular} & $\begin{array}{l}\text { Hoeg } 2021^{*} \\
\text { (US) }\end{array}$ & $\begin{array}{l}\text { Montgomery } \\
2021 \\
\text { (US) }\end{array}$ & $\begin{array}{l}\text { Rosner } 2021 \\
\text { (US) }\end{array}$ & $\begin{array}{l}\text { Larson } 2021 \\
\text { (Italy \& US) }\end{array}$ & $\begin{array}{l}\text { Mevorach } 2021 \\
\text { (Israel) }\end{array}$ & $\begin{array}{l}\text { Levin } 2021 \\
\text { (Israel) }\end{array}$ & $\begin{array}{l}\text { EudraVigilance } \\
\text { (European } \\
\text { Economic } \\
\text { Area) }\end{array}$ & $\begin{array}{l}\text { Schauer 2021* } \\
\text { (US) }\end{array}$ & $\begin{array}{l}\text { Su } 2021 \\
\text { (US) }\end{array}$ \\
\hline & & & & & & & & & $\begin{array}{l}103(2 \%)= \\
\text { Ad26.CoV.S } \\
\text { (Janssen) }\end{array}$ & & \\
\hline $\begin{array}{l}\text { Patients in } \\
\text { ICU, n }\end{array}$ & NR & $2(10 \%)$ & NR & NR & NR & $3(38 \%)$ & NR & $\mathrm{NR}$ & NR & 0 & 0 \\
\hline Hospitalized, n & NR & $19(95 \%)$ & $110(89 \%)$ & NR & $7(100 \%)$ & $8(100 \%)$ & $114(84 \%)$ & $7(100 \%)$ & $\mathrm{NR}$ & $13(100 \%)$ & NR \\
\hline $\begin{array}{l}\text { Patients } \\
\text { presenting } \\
\text { after second } \\
\text { vaccination }\end{array}$ & $6(100 \%)$ & $16(80 \%)$ & $\mathrm{NR}$ & $20(87 \%)$ & $5(71 \%)$ & $7(88 \%)$ & $117(86 \%)$ & $7(100 \%)$ & $\mathrm{NR}$ & $13(100 \%)$ & $6(75 \%)$ \\
\hline $\begin{array}{l}\text { Patients } \\
\text { COVID-19 } \\
\text { poly merase } \\
\text { chain reaction } \\
\text { positive }\end{array}$ & 0 (6/6 tested $)$ & $\mathrm{NR}$ & $\mathrm{NR}$ & 0 (19/23 tested) & $\begin{array}{l}0(6 / 7 \text { tested, all } \\
\text { negative) }\end{array}$ & 0 (8/8 tested) & $\mathrm{NR}$ & 0 (7/7 tested) & $\mathrm{NR}$ & $\mathrm{NR}$ & $\mathrm{NR}$ \\
\hline $\begin{array}{l}\text { Patients with } \\
\text { COVID } \\
\text { nucleocapsid } \\
\text { antibody } \\
\text { present } \\
\text { (among tested) }\end{array}$ & $\mathrm{NR}$ & $\mathrm{NR}$ & $\mathrm{NR}$ & $\mathrm{NR}$ & $\begin{array}{l}(4 / 7 \\
\text { tested, all } \\
\text { negative })\end{array}$ & $\mathrm{NR}$ & $\begin{array}{l}4(11 \%, 39 / 136 \\
\text { tested, 35/39 } \\
\text { negative) }\end{array}$ & $\begin{array}{l}2(100 \%, 2 / 7 \\
\text { tested) }\end{array}$ & $\mathrm{NR}$ & $\begin{array}{l}0(9 / 13 \text { tested, } \\
\text { all negative })\end{array}$ & $\mathrm{NR}$ \\
\hline $\begin{array}{l}\text { Patients with } \\
\text { SARS-CoV-2 } \\
\text { spike antibody }\end{array}$ & $\mathrm{NR}$ & $\mathrm{NR}$ & $\mathrm{NR}$ & $\mathrm{NR}$ & $\begin{array}{l}4(67 \%, 6 / 7 \\
\text { tested) } 2 \\
\text { presented } \\
\text { after first } \\
\text { vaccination }\end{array}$ & $\mathrm{NR}$ & $\begin{array}{l}62(100 \%, \\
62 / 136 \text { tested })\end{array}$ & $\begin{array}{l}2(100 \%, 2 / 7 \\
\text { tested) }\end{array}$ & $\mathrm{NR}$ & $\mathrm{NR}$ & $\mathrm{NR}$ \\
\hline $\begin{array}{l}\text { Time between } \\
\text { last vaccine } \\
\text { and sy mptom } \\
\text { onset, median } \\
\text { days, (range) }\end{array}$ & $3.5(2-4)$ & $3.5(\mathrm{IQR} 3-10.8)$ & NR & $2(1-4)$ & $\begin{array}{l} \\
3(2-7) \quad \text { Prese }\end{array}$ & $\frac{n}{3(2-4)}$ & $4(1-30)$ & $N R(1-5)$ & $\mathrm{NR}$ & $3(2-4)$ & $\begin{array}{l}3(0-12) \\
\text { One patient with } \\
12 \text { day onset } \\
\text { had history of } \\
\text { headache and } \\
\text { gastrointestinal } \\
\text { sy mptoms } 3 \text { or } 4 \\
\text { days before } \\
\text { chest pain; } \\
\text { potential viral } \\
\text { syndrome }\end{array}$ \\
\hline $\begin{array}{l}\text { Patients with } \\
\text { chest pain on } \\
\text { presentation }\end{array}$ & $\begin{array}{l}5(83 \%) \text { chest } \\
\text { pain } \\
1(17 \%) \text { non- } \\
\text { positional chest } \\
\text { pressure }\end{array}$ & $\mathrm{NR}$ & $\mathrm{NR}$ & $23(100 \%)$ & $7(100 \%)$ & $8(100 \%)$ & $129(95 \%)$ & $6(86 \%)$ & $\mathrm{NR}$ & $13(100 \%)$ & $7(88 \%)$ \\
\hline $\begin{array}{l}\text { Patients with } \\
\text { other } \\
\text { sy mptoms } \\
\text { (e.g., myalgia, } \\
\text { fatigue, fever) }\end{array}$ & $5(83 \%)$ & NR & $\mathrm{NR}$ & $\mathrm{NR}$ & $3(42 \%)$ & $5(63 \%)$ & $63(47 \%)$ & $6(86 \%)$ & $\mathrm{NR}$ & $8(62 \%)$ & $\mathrm{NR}$ \\
\hline
\end{tabular}




\begin{tabular}{|c|c|c|c|c|c|c|c|c|c|c|c|}
\hline $\begin{array}{l}\text { Case series } \\
\text { (Country) }\end{array}$ & $\begin{array}{l}\begin{array}{l}\text { Dickey 2021* } \\
\text { (US) }\end{array} \\
\end{array}$ & $\begin{array}{l}\text { Diaz } 2021 \\
\text { (US) }\end{array}$ & $\begin{array}{l}\text { Hoeg 2021* } \\
\text { (US) }\end{array}$ & $\begin{array}{l}\text { Montgomery } \\
2021 \\
\text { (US) }\end{array}$ & $\begin{array}{l}\text { Rosner } 2021 \\
\text { (US) }\end{array}$ & $\begin{array}{l}\text { Larson } 2021 \\
\text { (Italy \& US) }\end{array}$ & $\begin{array}{l}\text { Mevorach } 2021 \\
\text { (Israel) }\end{array}$ & $\begin{array}{l}\text { Levin } 2021 \\
\text { (Israel) }\end{array}$ & $\begin{array}{l}\text { EudraVigilance } \\
\text { (European } \\
\text { Economic } \\
\text { Area) }\end{array}$ & $\begin{array}{l}\text { Schauer 2021* } \\
\text { (US) }\end{array}$ & $\begin{array}{l}\text { Su } 2021 \\
\text { (US) }\end{array}$ \\
\hline $\begin{array}{l}\text { Patients with } \\
\text { troponin } \\
\text { elevation (of } \\
\text { tested) }\end{array}$ & $\begin{array}{l}6(100 \% \text {, all } \\
\text { tested) }\end{array}$ & $19(95 \%)$ & NR & $\begin{array}{l}23(100 \%, \text { all } \\
\text { tested })\end{array}$ & $\begin{array}{l}6(100 \%, 6 / 7 \\
\text { tested) }\end{array}$ & $8(100 \%)$ & $\begin{array}{l}136(100 \%, \text { all } \\
\text { tested) }\end{array}$ & $\begin{array}{l}7(100 \%, \text { all } \\
\text { tested })\end{array}$ & NR & $\begin{array}{l}13(100 \% \text {, all } \\
\text { tested); } \\
\text { median } 9.18 \\
\text { ng/mL, range } \\
0.65-18.5)\end{array}$ & $\begin{array}{l}8(100 \%, \text { all } \\
\text { tested })\end{array}$ \\
\hline $\begin{array}{l}\text { Median time to } \\
\text { troponin peak } \\
\text { after } \\
\text { vaccination, } \\
\text { days }\end{array}$ & Range 2-4 & NR & NR & NR & NR & 3 & NR & NR & NR & NR & NR \\
\hline $\begin{array}{l}\text { Patients with } \\
\text { BNP or NT pro } \\
\text { BNP elev ation } \\
\text { (among tested) }\end{array}$ & NR & NR & NR & NR & $\begin{array}{l}3(50 \%, 6 / 7 \\
\text { tested) }\end{array}$ & NR & $\begin{array}{l}\text { Tf examined, } \\
\text { modest NT Pro- } \\
\text { BNP elev ation }\end{array}$ & NR & NR & $\begin{array}{l}5(38 \%, 13 / 13 \\
\text { tested) }\end{array}$ & NR \\
\hline $\begin{array}{l}\text { Patients with } \\
\text { CRP elev ation } \\
\text { (among tested) }\end{array}$ & NR & NR & NR & NR & $\begin{array}{l}5(71 \%, 717 \\
\text { tested) }\end{array}$ & $\begin{array}{l}7(88 \%, 8 / 8 \\
\text { tested) }\end{array}$ & $\begin{array}{l}118(8 / \%, \\
136 / 136 \text { tested) }\end{array}$ & $\begin{array}{l}7(100 \%, \text { all } \\
\text { tested) }\end{array}$ & NR & $\begin{array}{l}10(100 \%, 10 / 13 \\
\text { tested) }\end{array}$ & NR \\
\hline $\begin{array}{l}\text { Patients with } \\
\text { eosinophilia } \\
\text { (among tested) }\end{array}$ & NR & NR & NR & NR & $\overline{N R}$ & 0 & NR & $\overline{N R}$ & NR & NR & NR \\
\hline $\begin{array}{l}\text { Patients with } \\
\text { abnormal ECG } \\
\text { (among tested) }\end{array}$ & $\begin{array}{l}6(100 \%, \text { all } \\
\text { tested); } \\
\text { ST elevation (5 } \\
\text { patients), } \\
\text { sinus rhy thm } \\
\text { with non-specific } \\
\text { T wave } \\
\text { abnormalities (1 } \\
\text { patient) }\end{array}$ & $\begin{array}{l}9(45 \%, 20 / 20 \\
\text { tested); } \\
\text { ST elev ation }\end{array}$ & NR & $\begin{array}{l}19(83 \%, 23 / 23 \\
\text { tested; } \\
\text { ST-segment } \\
\text { elevation, } \\
\text { T-wave } \\
\text { inversions, } \\
\text { nonspecific ST } \\
\text { changes }\end{array}$ & $\begin{array}{l}5(71 \%, 7 / 7 \\
\text { tested); } \\
\text { ST elevations (4 } \\
\text { patients), } \\
\text { nonspecific ST/T } \\
\text { changes (1 } \\
\text { patient) }\end{array}$ & $\begin{array}{l}7(88 \%, 8 / 8 \\
\text { tested); } \\
\text { ST elevation (6 } \\
\text { patients), } \\
\text { peaked Twaves } \\
\text { (1 patient), } \\
\text { normal (1 } \\
\text { patient) }\end{array}$ & $\begin{array}{l}93(68 \%, \\
136 / 136 \text { tested); } \\
\text { ECG changes }\end{array}$ & $\begin{array}{l}6(86 \%, 7 / 7 \\
\text { tested); } \\
\text { ST elev ation (5 } \\
\text { patients), } \\
\text { sinus } \\
\text { tachy cardia and } \\
\text { consistent with } \\
\text { MV and } \\
\text { hy pertrophy (1 } \\
\text { patient), normal } \\
\text { (1 patient) }\end{array}$ & NR & $\begin{array}{l}9(69 \%, 13 / 13 \\
\text { tested); } \\
\text { abnormal, } \\
\text { commonly ST } \\
\text { segment } \\
\text { elev ation }\end{array}$ & $\begin{array}{l}3(50 \%, 6 / 8 \\
\text { tested); } \\
\text { ST elevations ( } 2 \\
\text { patients), } \\
\text { non-specific ST } \\
\text { and T wave } \\
\text { changes (1 } \\
\text { patient) }\end{array}$ \\
\hline $\begin{array}{l}\text { Patients with } \\
\text { abnormal } \\
\text { cardiac MRI } \\
\text { (among tested) }\end{array}$ & $\begin{array}{l}5(83 \%, 6 / 6 \\
\text { tested); } \\
\text { abnormal left } \\
\text { v entricular } \\
\text { sy stolic function; } \\
\text { patchy } \\
\text { midmy ocardial } \\
\text { increased T2 } \\
\text { signal with } \\
\text { corresponding } \\
\text { late gadolinium } \\
\text { enhancement (5 } \\
\text { patients) }\end{array}$ & NR & NR & $\begin{array}{l}23(100 \%, \text { all } \\
\text { tested); } \\
\text { subepicardial } \\
\text { late gadolinium } \\
\text { enhancement or } \\
\text { focal myocardial } \\
\text { edema }\end{array}$ & $\begin{array}{l}7(100 \%, \text { all } \\
\text { tested); } \\
\text { LGE ( } 7 \\
\text { patients), } \\
\text { wall motion } \\
\text { abnormality (1 } \\
\text { patient), } \\
\text { my ocardial } \\
\text { edema in T2 (3 } \\
\text { patients) }\end{array}$ & $\begin{array}{l}8(100 \%, \text { all } \\
\text { tested); } \\
\text { LGE ( } 8 \\
\text { patients), edema } \\
\text { ( } 6 \text { patients) }\end{array}$ & $\begin{array}{l}48(100 \%, \\
48 / 136 \text { tested); } \\
\text { mild-to- } \\
\text { moderate } \\
\text { subepicardial } \\
\text { and } \\
\text { mid-my ocardial } \\
\text { late gadolinium } \\
\text { enhancement } \\
\text { (LGE) more } \\
\text { significantly } \\
\text { affecting the } \\
\text { lateral and } \\
\text { inferior LV } \\
\text { segments) }\end{array}$ & $\begin{array}{l}3(100 \%, 3 / 7 \\
\text { tested) }\end{array}$ & $\mathrm{NR}$ & $\begin{array}{l}13(100 \%, \text { all } \\
\text { tested); } \\
\text { abnormal } \\
\text { showing late } \\
\text { gadolinium } \\
\text { enhancement in } \\
\text { a patchy } \\
\text { subepicardial to } \\
\text { transmural } \\
\text { pattern with } \\
\text { predilection for } \\
\text { the inf erior left } \\
\text { ventricle free } \\
\text { wall }\end{array}$ & NR \\
\hline $\begin{array}{l}\text { Patients with } \\
\text { abnormal } \\
\text { echocardiogra } \\
\text { m (among } \\
\text { tested) }\end{array}$ & $\begin{array}{l}5(83 \%, 6 / 6 \\
\text { tested); } \\
\text { LVEF <50\% (3 } \\
\text { patients), } \\
\text { LVEF } \geq 50 \% \text { (2 } \\
\text { patient) }\end{array}$ & NR & NR & $\begin{array}{l}4(17 \%, 23 / 23 \\
\text { tested); } \\
\text { LVEF <50\% (4 } \\
\text { patients), } \\
\text { no structural } \\
\text { abnormality (23 } \\
\text { patients) }\end{array}$ & $\begin{array}{l}4(57 \%, 7 / 7 \\
\text { tested); } \\
\text { mild hy pokinesis } \\
\text { ( } 3 \text { patients), } \\
\text { low LVEF (1 } \\
\text { patient), }\end{array}$ & $\begin{array}{l}8(100 \% \text {, all } \\
\text { tested); } \\
\text { wall motion } \\
\text { abnormality with } \\
\text { regional or } \\
\text { generalized } \\
\text { hy pokinesis }\end{array}$ & NR & $\begin{array}{l}2(29 \%, 7 / 7 \\
\text { tested) }\end{array}$ & $\overline{N R}$ & $\begin{array}{l}2(15 \%, 13 / 13 \\
\text { tested); } \\
\text { left ventricular } \\
\text { wall notion } \\
\text { abnormalities } \\
\text { and LVEF <55\% } \\
\text { ( } 2 \text { patients) }\end{array}$ & $\begin{array}{l}1(20 \%, 5 / 8 \\
\text { tested); } \\
\text { mitral } \\
\text { regurgitation }\end{array}$ \\
\hline
\end{tabular}




\begin{tabular}{|c|c|c|c|c|c|c|c|c|c|c|c|}
\hline $\begin{array}{l}\text { Case series } \\
\text { (Country) }\end{array}$ & $\begin{array}{l}\text { Dickey 2021* } \\
\text { (US) }\end{array}$ & $\begin{array}{l}\text { Diaz } 2021 \\
\text { (US) }\end{array}$ & $\begin{array}{l}\text { Hoeg 2021* } \\
\text { (US) }\end{array}$ & $\begin{array}{l}\text { Montgomery } \\
2021 \\
\text { (US) }\end{array}$ & $\begin{array}{l}\text { Rosner } 2021 \\
\text { (US) }\end{array}$ & $\begin{array}{l}\text { Larson } 2021 \\
\text { (Italy \& US) }\end{array}$ & $\begin{array}{l}\text { Mevorach } 2021 \\
\text { (Israel) }\end{array}$ & $\begin{array}{l}\text { Levin } 2021 \\
\text { (Israel) }\end{array}$ & $\begin{array}{l}\text { EudraVigilance } \\
\text { (European } \\
\text { Economic } \\
\text { Area) }\end{array}$ & $\begin{array}{l}\text { Schauer 2021* } \\
\text { (US) }\end{array}$ & $\begin{array}{l}\text { Su } 2021 \\
\text { (US) }\end{array}$ \\
\hline & & & & & $\begin{array}{l}\text { midaLV } \\
\text { enlargement (1 } \\
\text { patient), } \\
\text { normal (3 } \\
\text { patients) }\end{array}$ & & & & & & \\
\hline $\begin{array}{l}\text { Patients with } \\
\text { LVEF< }<0 \% \\
\text { (among tested) }\end{array}$ & $\begin{array}{l}3(50 \%, 6 / 6 \\
\text { tested) }\end{array}$ & $\begin{array}{l}5(25 \%, 20 / 20 \\
\text { tested) }\end{array}$ & NR & $\begin{array}{l}4(17 \%, 23 / 23 \\
\text { tested) }\end{array}$ & $\begin{array}{l}1(14 \%, 7 / 7 \\
\text { tested); } \\
\text { LVEF } 35 \%-40 \% \\
\text { (1 patient) }\end{array}$ & $\begin{array}{l}2(25 \%, 8 / 8 \\
\text { tested); } \\
\text { LVEF 34\% (1 } \\
\text { patient), } \\
\text { LVEF 47\% (1 } \\
\text { patient) }\end{array}$ & $\begin{array}{l}4(3 \%) \text { sev erely } \\
\text { reduced (total } \\
\text { tested NR) }\end{array}$ & $\begin{array}{l}2(29 \%, 717 \\
\text { tested })\end{array}$ & NR & $\begin{array}{l}3(23 \%, 13 / 13 \\
\text { tested) }\end{array}$ & NR \\
\hline \multicolumn{12}{|c|}{ Outcome } \\
\hline $\begin{array}{l}\text { Patients with } \\
\text { sy mptoms } \\
\text { resolv ed }\end{array}$ & $6(100 \%)$ & $\begin{array}{l}20(100 \%) \\
\text { resolved/ } \\
\text { improved }\end{array}$ & NR & $16(70 \%)$ & $7(100 \%)$ & $8(100 \%)$ & $129(95 \%)$ & $7(100 \%)$ & $\begin{array}{l}2,581(46 \%) \\
\text { resolv ed/ } \\
\text { resolv ing, } \\
1571(28 \%) \\
\text { not resolv ed } \\
1234(22 \%) \\
\text { unknown } \\
112(2 \%) \\
\text { resolv ed/ } \\
\text { resolv ing with } \\
\text { sequelae }\end{array}$ & $13(100 \%)$ & $\begin{array}{l}5(83 \%, 6 / 8 \text { with } \\
\text { known } \\
\text { outcomes })\end{array}$ \\
\hline Fatalities, $n$ & 0 & 0 & NR & 0 & 0 & 0 & $\begin{array}{l}1(0.7 \%)(22- \\
\text { y ear-old with } \\
\text { fulminant } \\
\text { my ocarditis) }\end{array}$ & 0 & $84(1.5 \%)$ & 0 & 0 \\
\hline $\begin{array}{l}\text { Median } \\
\text { hospitalization } \\
\text { length of stay, } \\
\text { days (range) }\end{array}$ & NR & 2 (IQR 2-3) & NR & NR & $3(2-4)$ & $\begin{array}{l}\text { NR (all reported } \\
\text { as stable) }\end{array}$ & NR (3-4) & $4(1-5)$ & $\mathrm{NR}$ & $2(1-4)$ & $\overline{N R}$ \\
\hline $\begin{array}{l}\text { Patients } \\
\text { treated with } \\
\text { medications } \\
\text { for myocarditis }\end{array}$ & NR & $\begin{array}{l}15(75 \%)= \\
\text { NSAIDS } \\
9(45 \%)= \\
\text { colchicine } \\
0=\text { steroids }\end{array}$ & NR & NR & $\begin{array}{l}3(43 \%)= \\
\text { NSAIDS } \\
3(43 \%)= \\
\text { colchicine } \\
3(43 \%)= \\
\text { famotidine } \\
1(14 \%)= \\
\text { steroids }\end{array}$ & $\begin{array}{l}3(38 \%)= \\
\text { NSAID } \\
2(25 \%)= \\
\text { colchicine } \\
2(25 \%)= \\
\text { steroids }\end{array}$ & $\begin{array}{l}\text { Most treated } \\
\text { with NSAIDS, } \\
\text { with or without } \\
\text { colchicine }\end{array}$ & $\begin{array}{l}7(100 \%) ; \\
3(43 \%)= \\
\text { bisoprolol and } \\
\text { ramipril } \\
2(29 \%)= \\
\text { colchicine and } \\
\text { ibuprof en } \\
1(14 \%)= \\
\text { colchicine and } \\
\text { bisoprolol } \\
1(14 \%)= \\
\text { colchicine }\end{array}$ & NR & $\begin{array}{l}13(100 \%)= \\
\text { NSAID } \\
3(23 \%)= \\
\text { intrav enous } \\
\text { immune globulin } \\
2(15 \%)= \\
\text { corticosteroid }\end{array}$ & NR \\
\hline
\end{tabular}

Abbre viations: $\mathbf{C M R}=$ cardiovascular magnetic resonance imaging; $\mathbf{I C U}=$ intensive care unit; $\mathbf{L V E F}=$ left ventricular ejection fraction; $\mathbf{N R}=$ not reported; $\mathbf{N S ~ A I D ~}=$ non-steroidal anti-inflammatory drugs; PHAC $=$ Public Health Agency of Canada; VAERS $=$ vaccine adverse event reporting system; $\mathbf{y}=$ years

*Data for these series may overlap. 
Table 5. Results from Case Series with Short-term Follow-up of Pericarditis after COVID-19 Vaccination (Question 3b)

\begin{tabular}{|c|c|c|c|}
\hline Case series & $\begin{array}{l}\text { Diaz } 2021 \\
\text { (US) }\end{array}$ & $\begin{array}{l}\text { Hoeg } 2021 \\
\text { (US) }\end{array}$ & $\begin{array}{l}\text { EudraVigilance } \\
\text { (European Economic Area) }\end{array}$ \\
\hline Date of cases last updated & 25 May 2021 & 18 Jun 2021 & 25 Oct 2021 \\
\hline Cases of pericarditis, $n$ & 37 & 22 & 4250 \\
\hline Confirmed cases & $\begin{array}{l}\text { Clinically confirmed with troponin values or } \\
\text { cardiac MRI }\end{array}$ & $\begin{array}{l}\text { Inclusion criteria aligned with CDC working } \\
\text { case definition for probable pericarditis }\end{array}$ & Reported by healthcare or non-healthcare professionals \\
\hline Case source & $\begin{array}{l}40 \text { hospitals that were part of Providence health } \\
\text { care system and use same electronic medical } \\
\text { record (Washington, Oregon, Montana, Los } \\
\text { Angeles County, California) }\end{array}$ & VAERS & EudraVigilance \\
\hline Male, $n$ & $27(73 \%)$ & $20(91 \%)$ & $2299(54 \%)$ \\
\hline Median age (range), y & $59(46-69)$ & NR $(12-17)$ & NR \\
\hline Ages included & All agesincluded & Search limited to $12-17$ years & All agesincluded \\
\hline $\begin{array}{l}\text { Patients with pre-existing } \\
\text { conditions (excluding prior } \\
\text { COVID-19 infection, see } \\
\text { below) }\end{array}$ & $\begin{array}{l}\text { Alcohol or drug dependence =5 }(14 \%) ; \\
\text { coronary artery disease = } 4(11 \%) ; \\
\text { cancer = } 5(14 \%) ; \\
\text { heart failure }=2(5 \%) ; \\
\text { cirrosis = } 1(3 \%) ; \\
\text { chronic kidney disease = } 4(11 \%) ; \\
\text { COPD = } 4(11 \%) ; \\
\text { diabetes }=4(11 \%) ; \\
\text { hypertension = } 18(49 \%) ; \\
\text { autoimmune disease = } 3(8 \%)\end{array}$ & NR & NR \\
\hline $\begin{array}{l}\text { Patients with prior COVID- } \\
19 \text { history }\end{array}$ & NR & NR & NR \\
\hline Vaccine type, $n$ & $\begin{array}{l}23(62 \%)=\text { BNT 162b2 (Pfizer) } \\
12(32 \%)=\text { mRNA-1273 (Moderna) } \\
2(5 \%)=\text { Ad26.CoV.S (Janssen) }\end{array}$ & $146(100 \%)=$ BNT 162b2 (Pfizer) & $\begin{array}{l}2883(68 \%)=\text { BNT162b2 (Pfizer) } \\
850(20 \%)=\text { mRNA-1273 (Moderna) } \\
416(10 \%)=\text { AZD1222 (AstraZeneca) } \\
101(2 \%)=\text { Ad26.CoV.S (Janssen) }\end{array}$ \\
\hline Patientsin ICU & $1(3 \%)$ & NR & NR \\
\hline Hospitalized, n & $13(35 \%)$ & $16(73 \%)$ & NR \\
\hline $\begin{array}{l}\text { Patients presenting after } \\
\text { second vaccination }\end{array}$ & $22(60 \%)$ & NR & NR \\
\hline $\begin{array}{l}\text { Patients COVID-19 } \\
\text { polymerase chain reaction } \\
\text { positive }\end{array}$ & NR & NR & NR \\
\hline $\begin{array}{l}\text { Patients with COVID } \\
\text { nucleocapsidantibody } \\
\text { present (among tested) }\end{array}$ & NR & NR & NR \\
\hline $\begin{array}{l}\text { Patients with SARS-CoV-2 } \\
\text { spike antibody }\end{array}$ & NR & NR & NR \\
\hline $\begin{array}{l}\text { Time between last vaccine } \\
\text { and symptom onset, } \\
\text { median days, (range) }\end{array}$ & $20($ IQR 6-41) & NR & NR \\
\hline $\begin{array}{l}\text { Patients with chest pain on } \\
\text { presentation }\end{array}$ & NR & NR & NR \\
\hline
\end{tabular}




\begin{tabular}{|c|c|c|c|}
\hline Case series & $\begin{array}{l}\text { Diaz } 2021 \\
\text { (US) }\end{array}$ & $\begin{array}{l}\text { Hoeg } 2021 \\
\text { (US) }\end{array}$ & $\begin{array}{l}\text { EudraVigilance } \\
\text { (European Economic Area) }\end{array}$ \\
\hline $\begin{array}{l}\text { Patients with other } \\
\text { symptoms(e.g., myalgia, } \\
\text { fatigue, fever) }\end{array}$ & NR & NR & NR \\
\hline $\begin{array}{l}\text { Patientswith troponin } \\
\text { elevation (among tested) }\end{array}$ & 0 & NR & NR \\
\hline $\begin{array}{l}\text { Median time to troponin } \\
\text { peakafter vaccination, } \\
\text { days }\end{array}$ & NR & NR & NR \\
\hline $\begin{array}{l}\text { Patients with BNP orNT } \\
\text { pro BNP elevation (among } \\
\text { tested) }\end{array}$ & NR & NR & NR \\
\hline $\begin{array}{l}\text { Patients with CRP } \\
\text { elevation (among tested) }\end{array}$ & NR & NR & NR \\
\hline $\begin{array}{l}\text { Patients with eosinophilia } \\
\text { (among tested) }\end{array}$ & NR & NR & NR \\
\hline $\begin{array}{l}\text { Patients with abnormal } \\
\text { ECG (among tested) }\end{array}$ & $14(38 \%$, total tested NR) with ST elevation & NR & NR \\
\hline $\begin{array}{l}\text { Patients with abnormal } \\
\text { cardiac MRI (among } \\
\text { tested) }\end{array}$ & NR & NR & NR \\
\hline $\begin{array}{l}\text { Patients with abnormal } \\
\text { echocardiogram (among } \\
\text { tested) }\end{array}$ & NR & NR & NR \\
\hline $\begin{array}{l}\text { Patients with LVEF }<50 \% \\
\text { (among tested) }\end{array}$ & $3(8 \%$, total tested $N R)$ & NR & NR \\
\hline $\begin{array}{l}\text { Patients with symptoms } \\
\text { resolved }\end{array}$ & $\begin{array}{l}30(81 \%) \text { resolved/improved } \\
2(5 \%) \text { persistent } \\
5(14 \%) \text { unknown }\end{array}$ & NR & $\begin{array}{l}2083(49 \%) \text { resolved/ resolving } \\
1318(31 \%) \text { not resolved } \\
808(19 \%) \text { unknown } \\
43(1 \%) \text { resolved/ resolving with sequelae }\end{array}$ \\
\hline Fatalities, $n$ & 0 & NR & $15(0.4 \%)$ \\
\hline $\begin{array}{l}\text { Median hospitalization } \\
\text { length of stay, days } \\
\text { (range) }\end{array}$ & 1 (IQR 1-2) & NR & NR \\
\hline $\begin{array}{l}\text { Patients treated with } \\
\text { medicationsfor pericarditis }\end{array}$ & $\begin{array}{l}18(49 \%) \text { NSAIDs } \\
20(54 \%) \text { colchicine } \\
4(11 \%) \text { steroids } \\
\end{array}$ & NR & NR \\
\hline
\end{tabular}

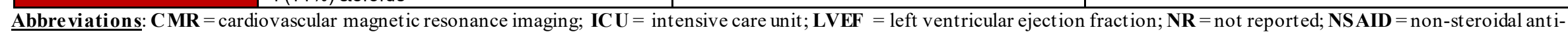
inflammatory drugs. 
Table 6. Case Series of Longer-term Follow-up of Myocarditis or Pericarditis after mRNA COVID-19 Vaccination (Question 4)

\begin{tabular}{|c|c|c|c|}
\hline Case series (country) & $\begin{array}{l}\text { Chelala } 2021 \\
\text { (US) }\end{array}$ & $\begin{array}{l}\text { Patel } 2021 \\
\text { (US) }\end{array}$ & $\begin{array}{l}\text { Klein } 2022 \\
\text { (US) }\end{array}$ \\
\hline Date of cases last updated & 14 June 2021 & June 2021 & $25 \operatorname{Dec} 2021$ \\
\hline Cases, $\mathbf{n}$ & 5 & 9 & 43 \\
\hline Confirmed cases & $\begin{array}{l}\text { Clinically confirmed through review of } \\
\text { medical records, results of biochemical } \\
\text { laboratory testing, ECG results, and findings } \\
\text { from echocardiography, cardiac MRI; met } \\
2018 \text { Lake Louise criteria }\end{array}$ & $\begin{array}{l}\text { Diagnoses reviewed and met the CDC case } \\
\text { definition and troponin elevation }\end{array}$ & $\begin{array}{l}\text { TCD-10 used then diagnosesconfirmed } \\
\text { by medical record review }\end{array}$ \\
\hline Case source & Single medical centre inUSA & Single medical centre in Atlanta, USA & $\begin{array}{l}\text { KaiserPermanente in Colorado, } \\
\text { Oregon, California, and Washington; } \\
\text { HealthPartners Institute Minnesota; } \\
\text { Denver Health }\end{array}$ \\
\hline Myocarditis, $\mathbf{n}$ & $5(100 \%)$ & $9(100 \%)$ & $23(53 \%)$ \\
\hline Pericarditis, $\mathbf{n}$ & 0 & 0 & $2(5 \%)$ \\
\hline Myopericarditis, $n$ & 0 & 0 & $18(42 \%)$ \\
\hline Male, $n$ & $5(100 \%)$ & $9(100 \%)$ & $37(86 \%)$ \\
\hline $\begin{array}{l}\text { Median age (range), y } \\
\text { Ages included }\end{array}$ & Mean $=17(16-19)$ & $15.7(\operatorname{IQR} 14.5-16.6)$ & $\begin{array}{l}29(67 \%) 12-15 \text { years } \\
14(33 \%) 16-17 \text { years }\end{array}$ \\
\hline Vaccine product, $n$ & $\begin{array}{l}4(80 \%) \text { BNT162b2 (Pfizer) } \\
1(20 \%) \text { mRNA-1273 (Moderna) }\end{array}$ & $9(100 \%)$ mRNA vaccine & $43(100 \%)$ BNT 162b2 (Pfizer) \\
\hline Patients in ICU & NR & $2(22 \%)$ & $11(26 \%)$ \\
\hline Hospitalized, $n$ & $5(100 \%)$ & $9(100 \%)$ & $28(65 \%)$ \\
\hline $\begin{array}{l}\text { Patients presenting after second } \\
\text { vaccination }\end{array}$ & $5(100 \%)$ & $8(89 \%)$ & NR \\
\hline $\begin{array}{l}\text { Patients with prior COVID-19 } \\
\text { history }\end{array}$ & 0 & $\mathrm{NR}$ & $2(5 \%)$ \\
\hline $\begin{array}{l}\text { Patients COVID- } 19 \text { polymerase } \\
\text { chain reaction positive }\end{array}$ & 0 & NR & NR \\
\hline $\begin{array}{l}\text { Patients with COVID } \\
\text { nucleocapsid antibody present } \\
\text { (among tested) }\end{array}$ & NR & NR & NR \\
\hline $\begin{array}{l}\text { Patients with SARS-CoV-2 spike } \\
\text { antibody }\end{array}$ & NR & NR & NR \\
\hline $\begin{array}{l}\text { Patients with prior myocarditis or } \\
\text { pericarditis history }\end{array}$ & $\begin{array}{l}0 \text { reported significant cardiovascular risk } \\
\text { factors or history of previous cardiovascular } \\
\text { events }\end{array}$ & NR & $2(5 \%)$ \\
\hline $\begin{array}{l}\text { Time between last vaccine and } \\
\text { symptom onset, median days, } \\
\text { (range) }\end{array}$ & $4(3-4)$ & $\begin{array}{l}\text { Median } 3 \text { daysbetween } 2^{\text {na }} \text { vaccination } \\
\text { and hospital admission }\end{array}$ & $2(0-20)$ \\
\hline $\begin{array}{l}\text { Patients with chest pain on } \\
\text { presentation }\end{array}$ & $5(100 \%)$ & $9(100 \%)$ & NR \\
\hline $\begin{array}{l}\text { Patients with other symptoms } \\
\text { (eg, myalgia, fatigue, fever) }\end{array}$ & NR & $4(44 \%)$ dyspnea & NR \\
\hline $\begin{array}{l}\text { Patients with troponin elevation } \\
\text { (among tested) }\end{array}$ & $5(100 \%$, all tested $)$ & NR & NR \\
\hline
\end{tabular}




\begin{tabular}{|c|c|c|c|}
\hline $\begin{array}{l}\text { Median time to troponin peak } \\
\text { after v accination, days }\end{array}$ & $\mathrm{NR}$ & $\mathrm{NR}$ & $\mathrm{NR}$ \\
\hline $\begin{array}{l}\text { Patients with BNP or NT-proBNP } \\
\text { elevation (among tested) }\end{array}$ & $\begin{array}{l}0 ; \\
\text { normal }(4 / 4 \text { tested })\end{array}$ & NR & NR \\
\hline $\begin{array}{l}\text { Patients with CRP elev ation } \\
\text { (among tested) }\end{array}$ & $4(80 \%, 5 / 5$ tested $)$ & NR & NR \\
\hline $\begin{array}{l}\text { Patients with eosinophilia } \\
\text { (among tested) }\end{array}$ & NR & NR & NR \\
\hline $\begin{array}{l}\text { Patients with abnormal ECG } \\
\text { (among tested) }\end{array}$ & $\begin{array}{l}2(40 \%, 5 / 5 \text { tested); } \\
\text { ST segment elevation ( } 1 \text { patient), } \\
\text { sinus bradycardia ( } 1 \text { patient), } \\
\text { normal ( } 3 \text { patients) }\end{array}$ & $\begin{array}{l}6(67 \%, 9 / 9 \text { tested); } \\
\text { repolarization abnormalities (6 patients), } \\
\text { normal ( } 3 \text { patients) }\end{array}$ & NR \\
\hline $\begin{array}{l}\text { Patients with abnormal cardiac } \\
\text { MRI (among tested) }\end{array}$ & $\begin{array}{l}5(100 \%, 5 / 5 \text { tested }) \\
\text { no segmental wall motionsabnormalities, } \\
\text { and basilar and mid-cavity invol vement; early } \\
\text { and late gadolinium enhancement }\end{array}$ & NR & NR \\
\hline $\begin{array}{l}\text { Patients with abnormal } \\
\text { echocardiogram (among tested) }\end{array}$ & $\begin{array}{l}2(40 \%, 5 / 5 \text { tested); } \\
\text { LVEF mildly to moderately decreased and } \\
\text { associated with global hypokinesis ( } 1 \\
\text { patient), } \\
\text { ectasia of right coronary artery and left } \\
\text { anterior descending artery ( } 1 \text { patient), nomal } \\
\text { (3 patients) }\end{array}$ & $\begin{array}{l}\text { Median (IQR)LVEF at presentation }=60 \\
(58-67)\end{array}$ & NR \\
\hline $\begin{array}{l}\text { Patients with LVEF }<50 \% \text { (among } \\
\text { tested) }\end{array}$ & $1(20 \%)$ & $\begin{array}{l}2(22 \%) \text { with } 30-55 \% \text { LVEF at presentation } \\
7(78 \%) \text { with }>55 \% \text { LVEF at presentation }\end{array}$ & NR \\
\hline Patients with symptoms resolved & $5(100 \%)$ & NR & $43(100 \%)$ discharged home \\
\hline Fatalities, $\mathbf{n}$ & 0 & 0 & 0 \\
\hline $\begin{array}{l}\text { Median hospitalization length of } \\
\text { stay, days (range) }\end{array}$ & $3(3-9)$ & NR & $2(0-7)$ \\
\hline $\begin{array}{l}\text { Patients treated with medications } \\
\text { for myocarditis }\end{array}$ & $\begin{array}{l}\text { Prescribed at discharge: } \\
1(20 \%) \text { colchicine and metoprolol } \\
1(20 \%) \text { metoprolol } \\
1(20 \%) \text { NSAID } \\
1(20 \%) \text { aspirin }\end{array}$ & $\begin{array}{l}8(89 \%) \text { other NSAID if no aspirin } \\
2(22 \%) \text { vasopressors } \\
1(11 \%) \text { IVIG } \\
1(11 \%) \text { aspirin } \\
0 \text { steroids }\end{array}$ & $\overline{N R}$ \\
\hline $\begin{array}{l}\text { Number of patients with follow- } \\
\text { up data }\end{array}$ & $5 / 5(100 \%)$ & $9 / 9(100 \%)$ & $24 / 43(56 \%)$ \\
\hline $\begin{array}{l}\text { Mean length clinical follow -up } \\
\text { (range), days }\end{array}$ & $95(92-104)$ & $90(\mathrm{NR})$ & $88.5(28-153)$ \\
\hline Repeat cardiac MRI, n & $2(40 \%)$ & NR & $1(4 \%)$ \\
\hline $\begin{array}{l}\text { Characteristics of repeat cardiac } \\
\text { MRI }\end{array}$ & $\begin{array}{l}2 \text { performed, both stable biventricular size } \\
\text { and function; persistent, but decreased, LGE } \\
\text { that was similar in distribution to the initial } \\
\text { MRI; and an absence of new areas of } \\
\text { abnormality }\end{array}$ & NR & Normal findings \\
\hline Symptoms such as chest pain, $n$ & $\begin{array}{l}3(60 \%) \\
\text { mild intermittent self-resolving chest pain } \\
\text { after discharge; in one patient recurrent } \\
\text { symptomsoccurred after discontinuation of } \\
\text { the NSAID prescribed at discharge }\end{array}$ & NR & $\begin{array}{l}9(38 \%) \text { chest pain } \\
3(13 \%) \text { shortness of breath } \\
3(13 \%) \text { palpitations } \\
1(4 \%) \text { fatigue }\end{array}$ \\
\hline
\end{tabular}




\begin{tabular}{|c|c|c|c|}
\hline & & & $\begin{array}{l}3(13 \%) \text { other (e.g., orthostatic } \\
\text { hypotension, dizziness) }\end{array}$ \\
\hline $\begin{array}{l}\text { Medical visits following } \\
\text { discharge, } n\end{array}$ & $\begin{array}{l}3(60 \%) ; \\
\text { recurrent symptoms resulted in an } \\
\text { emergency department visit }\end{array}$ & $\begin{array}{l}\text { ECG findingsat clinic follow up }(1-2 \text { weeks } \\
\text { after discharge): } \\
1(17 \%) \text { repolarization abnormalities, } \\
5(83 \%) \text { normal }\end{array}$ & $\begin{array}{l}18(75 \%) \text { electrocardiogram, with } \\
\text { abnormal findingsin } 9(50 \%) \text { patients; } \\
17(71 \%) \text { echocardiogram, with } \\
\text { abnormal findingsin } 2(12 \%) \text { patients }\end{array}$ \\
\hline $\begin{array}{l}\text { Continued treatment with } \\
\text { medications, } n\end{array}$ & NR & 0 on heart failure medication & $\begin{array}{l}2(8 \%) \text { still on medication (e.g., } \\
\text { NSAIDs, colchicine) }\end{array}$ \\
\hline Recovered with no symptoms, $n$ & NR & NR & $\begin{array}{l}11(46 \%) \text { no symptoms, medications, or } \\
\text { exercise restrictions }\end{array}$ \\
\hline
\end{tabular}

Abbre viations: BNP/NT-proBNP = B-type natriuretic peptide/ N-terminal pro B-type natriuretic peptide; $\mathbf{C D C}=$ Centers for Disease Control and Prevention; $\mathbf{C} \mathbf{R P}=\mathrm{c}-$ reactive protein; $\mathbf{E C G}=$ echocardiogram; $\mathbf{I C D}=$ International Classification of Diseases; $\mathbf{I C} \mathbf{U}=$ intensive care unit; $\mathbf{I Q} \mathbf{R}=$ interquartile range; $\mathbf{I V I G}=$ intravenous immune globulin; LGE = late gadolinium enhancement; $\mathbf{L V E F}=$ left ventricular ejection fraction; $\mathbf{M R I}=$ magnetic resonance imaging; $\mathbf{m} \mathbf{R N A}=$ messenger ribonucleic acid; $\mathbf{N A}=$ not applicable; NR = not reported; NSAID = non-steroidal anti-inflammatory drugs; PHAC = Public Health Agency of Canada; VAERS = vaccine adverse event reporting system

Table 7. Hypothesized mechanisms for myocarditis following mRNA COVID-19 vaccination and direct (i.e., on myocarditis after COVID-19 vaccine) supporting/refuting empirical evidence (Question 5)

\begin{tabular}{|c|c|c|c|c|}
\hline \multirow{2}{*}{\multicolumn{2}{|c|}{ Hypothesis }} & \multirow[t]{2}{*}{ Citations } & \multicolumn{2}{|c|}{ Direct Empirical Evidence } \\
\hline & & & Supporting & Refuting \\
\hline 1 & $\begin{array}{l}\text { Hyper immune/inflammatory response, via exposure } \\
\text { to spike protein, mRNA strand, or unknown trigger }\end{array}$ & $\begin{array}{l}\mathrm{N}=9 \\
\text { Hajra et al., } 2021^{58} \\
\text { Tsilingiris et al., } 2021^{68} \\
\text { Heymans \& Cooper, } 2021^{59} \\
\text { Parra-Lucareset al., } 2021^{64} \\
\text { Bozkurt et al, } 2021^{9} \\
\text { Das et al., } 2021^{55} \\
\text { Boursier, } 2021^{52} \\
\text { Switzer \& Loeb, } 2021^{65} \\
\text { Verma et al., } 2021^{69}\end{array}$ & $\begin{array}{l}\text { - } 3 \text { case reports } \\
\text { - Multiple case series/reports } \\
\text { reporting highest incidence in } \\
\text { youth who have higher } \\
\text { immunogenicity and reactogenicity } \\
\text { from vaccines }\end{array}$ & $\begin{array}{l}-2 \text { case reports } \\
-1 \text { case series }\end{array}$ \\
\hline 2 & Delayedhypersensitivity (serum sickness) & $\begin{array}{l}\mathrm{N}=5 \\
\text { Hajra et al } 2021^{58} \\
\text { Tsilingiriset al., } 2021^{68} \\
\text { D'Angelo et al, } 2021^{54} \\
\text { Bozkurt et al., } 2021^{9} \\
\text { Chouchana et al., } 2021^{53}\end{array}$ & $\begin{array}{l}-1 \text { case report } \\
-1 \text { case series }\end{array}$ & $\begin{array}{l}-6 \text { case reports } \\
-6 \text { case series }\end{array}$ \\
\hline 3 & Eosinophilic myocarditis & $\begin{array}{l}\mathrm{N}=4 \\
\text { Hajra et al } 2021^{58} \\
\text { Takeda et al. } 2021^{66} \\
\text { D'Angelo et al, } 2021^{54} \\
\text { Bozkurt et al, } 2021^{9}\end{array}$ & - 1 case report & $\begin{array}{l}-6 \text { case reports } \\
-6 \text { case series }\end{array}$ \\
\hline 4 & $\begin{array}{l}\text { Hypersensitivity to vaccine vehicle components(e.g., } \\
\text { polyethylene glycol [PEG] and tromethamine; lipid } \\
\text { nanoparticle sheath) }\end{array}$ & $\begin{array}{l}\mathrm{N}=4 \\
\text { Kouniset al. 2021 } \mathrm{a}^{62} \\
\text { Kouniset al. 2021 } \mathrm{b}^{61} \\
\text { Tsilingiriset al., 2021 }\end{array}$ & $\begin{array}{l}\text { - } 4 \text { case reports (1 case with biopsy } \\
\text { in series) } \\
-1 \text { cohort study }\end{array}$ & $\begin{array}{l}-6 \text { several case reports } \\
-6 \text { case series }\end{array}$ \\
\hline
\end{tabular}




\begin{tabular}{|c|c|c|c|c|}
\hline & & Bozkurt et al., $2021^{9}$ & & \\
\hline 5 & $\begin{array}{l}\text { Response to mRNA vaccine lipid nanoparticles } \\
\text { (direct deleterious effect; not delayed - see } \\
\text { hypothesis 4) }\end{array}$ & $\begin{array}{l}\mathrm{N}=2 \\
\text { Tsilingiriset al., } 2021^{68} \\
\text { Kadkhoda et al., } 2021^{60}\end{array}$ & -1 cohort & None \\
\hline 6 & $\begin{array}{l}\text { Autoimmunity triggered by molecular mimicry or } \\
\text { other mechanism }\end{array}$ & 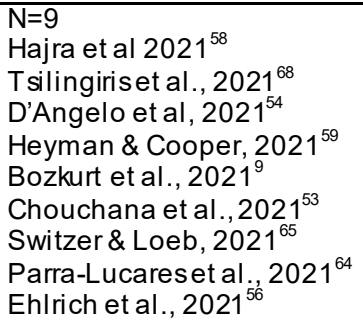 & $\begin{array}{l}\text { Molecular mimicry: } \\
-2 \text { case reports } \\
-1 \text { case series } \\
-1 \text { in vitro study } \\
\text { Other autoimmune: } \\
-1 \text { case report }\end{array}$ & $\begin{array}{l}\text { Molecular mimicry: } \\
-3 \text { cohorts/registry } \\
-2 \text { case reports } \\
\text { Other autoimmune: direct findings } \\
\text { indicated but not cited }\end{array}$ \\
\hline 7 & Low residual levels of double-strand RNA (dsRINA) & $\begin{array}{l}\mathrm{N}=1 \\
\text { Milano et al } 2021^{4}\end{array}$ & None & None \\
\hline 8 & Dysregulated micro-RNA response & $\begin{array}{l}\mathrm{N}=1 \\
\text { AbdelMassih et al. } 2021^{51}\end{array}$ & None & None \\
\hline 9 & $\begin{array}{l}\text { Production of anti-idiotype antibodies against } \\
\text { immunogenic regions of antigen-specific antibodies }\end{array}$ & $\begin{array}{l}\mathrm{N}=1 \\
\text { Tsilingiriset al., } 2021^{68}\end{array}$ & None & None \\
\hline 10 & $\begin{array}{l}\text { Trigger of pre-existing dysregulatedimmune } \\
\text { pathwaysin certain individuals with predispositions } \\
\text { (e.g., resulting in a polyclonal B-cell expansion, } \\
\text { immune complex formation, and inflammation }^{9} \text { ) }\end{array}$ & $\begin{array}{l}\mathrm{N}=2 \\
\text { Bozkurt et al., } 2021^{9} \\
\text { Switzer \& Loeb, } 2021^{65}\end{array}$ & None & $\begin{array}{l}\text { For specific predispositions: } \\
1 \text { - case report } \\
1 \text { - case series }\end{array}$ \\
\hline 11 & $\begin{array}{l}\text { Antibody-dependent enhancement of immunity or } \\
\text { other forms of immune enhancement with re- } \\
\text { exposure to virus after vaccine }\end{array}$ & $\begin{array}{l}\mathrm{N}=1 \\
\text { Bozkurt et al., } 2021^{9}\end{array}$ & None & $\begin{array}{l}\text { Multiple case reportsand series } \\
\text { reviewed and tabulated, having no } \\
\text { evidence of acute COVID-19 infections } \\
\text { after vaccine when presenting with } \\
\text { myocarditis }\end{array}$ \\
\hline 12 & $\begin{array}{l}\text { Direct cell invasion via the spike protein interacting } \\
\text { with the angiotensin-converting enzyme } 2 \text { (ACE2) } \\
\text { widely expressed and prevalent in cardiomyocytes }\end{array}$ & $\begin{array}{l}\mathrm{N}=2 \\
\text { Chouchana et al., } 2021^{53} \\
\text { Switzer \& Loeb, } 2021^{65}\end{array}$ & None & -2 cases \\
\hline 13 & $\begin{array}{l}\text { Cardiac pericyte expression of ACE2 with } \\
\text { immobilized immune complex on the surface of } \\
\text { pericytes activation of the complement system }\end{array}$ & $\begin{array}{l}\mathrm{N}=1 \\
\text { Kadkhoda et al., } 2021^{60}\end{array}$ & None & None \\
\hline 14 & $\begin{array}{l}\text { Spike-activated neutrophils(expressing ACE2) } \\
\text { augmenting inflammatory response }\end{array}$ & $\begin{array}{l}\mathrm{N}=2 \\
\text { Kadkhoda et al., } 2021^{60} \\
\text { Choi et al., } 2021^{87}\end{array}$ & - 1 case report & None \\
\hline 15 & Hyperviscosity-induced cardiac problem & $\begin{array}{l}\mathrm{N}=1 \\
\text { Mungmunpuntipantip \& } \\
\text { Wiwanitkit, } 2021^{70}\end{array}$ & None & None \\
\hline 16 & $\begin{array}{l}\text { Strenuous exercise induced secretion of } \\
\text { proinflammatory IL-6 }\end{array}$ & $\begin{array}{l}\mathrm{N}=1 \\
\text { Elkazzaz et al., } 2022^{57}\end{array}$ & None & None \\
\hline \multicolumn{5}{|c|}{ Observation } \\
\hline & $\begin{array}{l}\text { Differencesin incidence by sex could be due to sex } \\
\text { steroid hormonesor under-diagnosis in females }\end{array}$ & $\begin{array}{l}\mathrm{N}=5 \\
\text { Tsilingiriset al., } 2021^{68} \\
\text { Heymans \& Cooper, } 2021^{59} \\
\text { Bozkurt et al., } 2021^{9} \\
\text { Chouchana et al., } 2021^{53} \\
\text { Parra-Lucareset al., } 2021^{64}\end{array}$ & $\begin{array}{l}\text { Sexhormones: None } \\
\text { Underdiagnosisin women: } 2 \text { reports } \\
\text { (not studies) }\end{array}$ & $\begin{array}{l}\text { Sexhormones: } \\
-1 \text { cohort } \\
\text { Underdiagnosisin women: None }\end{array}$ \\
\hline
\end{tabular}


medRxiv preprint doi: https://doi.org/10.1101/2022.02.28.22271643; this version posted March 1, 2022. The copyright holder for this preprint (which was not certified by peer review) is the author/funder, who has granted medRxiv a license to display the preprint in perpetuity.

$$
\text { It is made available under a CC-BY-NC } 4.0 \text { International license. }
$$

